\title{
Recyclable Gold Catalyst for the Stereoselective Thioallylation of Alkynes
}

\author{
Wenli Hu, Bingbo Niu, Xiaoqiang Xiao, Mingzhong Cai* \\ Key Laboratory of Functional Small Organic Molecule, Ministry of Education and College of \\ Chemistry \& Chemical Engineering, Jiangxi Normal University, Nanchang 330022, China \\ E-mail: mzcai@jxnu.edu.cn
}

\section{Supporting Information}

Table of Contents

1. Preparation of the Silylated NHC-AuCl Complex [(EtO) $\left.)_{3} \mathrm{Si}-\mathrm{IPrAuCl}\right] \quad$ S2-S3

$\begin{array}{ll}\text { 2. Characterization of the MCM-41-IPrAuNTf } & \text { Complex }\end{array}$

3. NMR Spectra of Compounds 3a-r, 5a-p and 7a-f S9-S48 


\section{Preparation of the Silylated NHC-AuCl Complex [(EtO) 3 Si-IPrAuCl]}

\subsection{Preparation of 1,3-bis(2,6-diisopropyl-4-[3-(triethoxysilyl)propyl]phenyl)- imidazolium chloride. ${ }^{1}$}

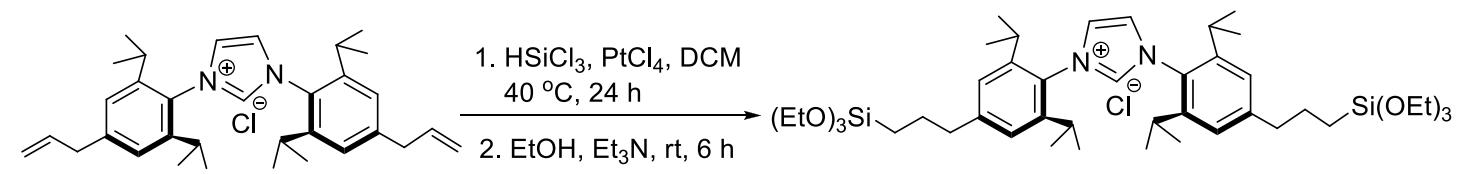

An oven-dried Schlenk tube equipped with a magnetic stir bar was charged with 10 $\mathrm{mL}$ of $\mathrm{CH}_{2} \mathrm{Cl}_{2}$ and 1,3-bis(4-allyl-2,6-diisopropylphenyl)imidazolium chloride ${ }^{2}$ (260 mg, $0.5 \mathrm{mmol})$ under Ar. To the resulting solution $\mathrm{HSiCl}_{3}(3 \mathrm{~mL}, 29.6 \mathrm{mmol})$ was dropwise added with vigorous stirring, followed by the addition of $\mathrm{PtCl}_{4}(16.8 \mathrm{mg}$, $0.05 \mathrm{mmol})$. The reaction mixture was refluxed for $24 \mathrm{~h}$ and cooled down to room temperature. The volatiles were evaporated under reduced pressure and collected in a secondary cold trap. The residue was dissolved in $\mathrm{CH}_{2} \mathrm{Cl}_{2}(10 \mathrm{~mL})$ and the tube was cooled in an ice bath. An EtOH/Et ${ }_{3} \mathrm{~N}$ (1:1) mixture $(4 \mathrm{~mL})$ was then dropwise added to the solution and the reaction mixture was allowed to reach room temperature and stirred for $6 \mathrm{~h}$. The volatiles were evaporated and the residue was purified by silica column chromatography using a $\mathrm{CH}_{2} \mathrm{Cl}_{2}: \mathrm{MeOH}(10: 1)$ mixture as eluent. The desired silylated product was obtained as a brown sticky solid $\left(254.3 \mathrm{mg}, 61 \%\right.$ yield). ${ }^{1} \mathrm{H}$ NMR (400 MHz, $\left.\mathrm{CDCl}_{3}\right): \delta 9.22(\mathrm{~s}, 1 \mathrm{H}), 8.18(\mathrm{~s}, 2 \mathrm{H}), 7.07(\mathrm{~s}, 4 \mathrm{H}), 3.78(\mathrm{q}, J=7.2$ $\mathrm{Hz}, 12 \mathrm{H}), 2.68-2.64(\mathrm{~m}, 4 \mathrm{H}), 2.35(\mathrm{~m}, 4 \mathrm{H}), 1.22(\mathrm{~d}, J=6.8 \mathrm{~Hz}, 12 \mathrm{H}), 1.75(\mathrm{~m}, 4 \mathrm{H})$, $1.19(\mathrm{t}, J=7.0 \mathrm{~Hz}, 18 \mathrm{H}), 1.14(\mathrm{~d}, J=6.8 \mathrm{~Hz}, 12 \mathrm{H}), 0.67-0.62(\mathrm{~m}, 4 \mathrm{H}) ;{ }^{13} \mathrm{C}\left\{{ }^{1} \mathrm{H}\right\} \mathrm{NMR}$ (100 MHz, $\left.\mathrm{CDCl}_{3}\right): \delta 146.8,144.8,137.2,127.8,127.7,126.0,124.8,58.4,39.3,29.1$, $24.8,24.7,23.9,18.4,10.4$.

\subsection{Preparation of the Silylated NHC-AuCl Complex $\left[(\mathrm{EtO})_{3} \mathrm{Si}-\mathrm{IPrAuCl}\right]^{3}$}

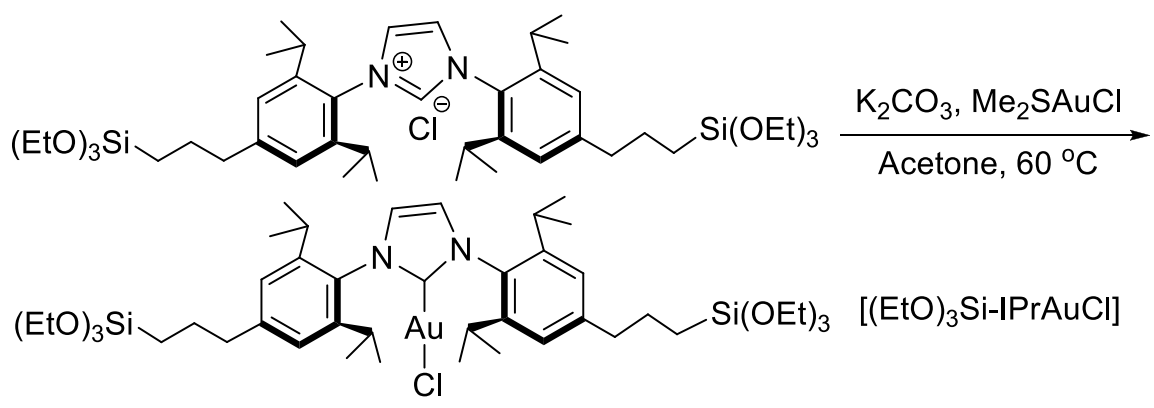


An oven-dried Schlenk tubbe equipped with a magnetic stir bar was charged with 1,3-bis(2,6-diisopropyl-4-[3-(triethoxysilyl)propyl]phenyl)imidazolium chloride (91.6 $\mathrm{mg}, 0.11 \mathrm{mmol}), \mathrm{Me}_{2} \mathrm{SAuCl}(32.4 \mathrm{mg}, 0.11 \mathrm{mmol})$ and $0.5 \mathrm{~mL}$ of acetone under $\mathrm{Ar}$. The resulting mixture was stirred for $15 \mathrm{~min}$ at room temperature and $\mathrm{K}_{2} \mathrm{CO}_{3}(30.4$ $\mathrm{mg}, 0.2 \mathrm{mmol}$ ) was then added. The reaction mixture was warmed up and stirred at $60{ }^{\circ} \mathrm{C}$ for $2 \mathrm{~h}$. The solvent was evaporated and the residue was re-dissolved in $\mathrm{CH}_{2} \mathrm{Cl}_{2}$. The resulting suspension was filtered through Celite and the solid was washed with $\mathrm{CH}_{2} \mathrm{Cl}_{2}$. The solvent was removed under reduced pressure and the residue was purified by silica column chromatography using a $\mathrm{CH}_{2} \mathrm{Cl}_{2}$ :hexane (6:1) mixture as eluent to afford the desired silylated $\mathrm{NHC}-\mathrm{AuCl}$ complex [(EtO) $\left.{ }_{3} \mathrm{Si}-\mathrm{IPrAuCl}\right]$ as a brown solid in $63 \%$ yield $(71.4 \mathrm{mg}) .{ }^{1} \mathrm{H} \mathrm{NMR}\left(400 \mathrm{MHz}, \mathrm{CDCl}_{3}\right): \delta 7.18(\mathrm{~s}, 2 \mathrm{H}), 6.98$ (s, 4H), 3.79 (q, J = 7.2 Hz, 12H), 2.68-2.56 (m, 4H), $2.43(\mathrm{~m}, 4 \mathrm{H}), 1.80-1.66(\mathrm{~m}, 4 \mathrm{H})$, $1.24(\mathrm{~d}, J=6.8 \mathrm{~Hz}, 12 \mathrm{H}), 1.17(\mathrm{t}, J=7.2 \mathrm{~Hz}, 18 \mathrm{H}), 1.11(\mathrm{~d}, J=6.8 \mathrm{~Hz}, 12 \mathrm{H})$, 0.70-0.55 (m, 4H). ${ }^{13} \mathrm{C}\left\{{ }^{1} \mathrm{H}\right\}$ NMR (100 MHz, $\left.\mathrm{CDCl}_{3}\right): \delta 175.4,145.3,144.9,131.7$, $123.8,123.2,58.4,39.2,28.9,24.7,23.5,18.4,10.3$.

\section{REFERENCES}

(1) Allen, D. P.; Van Wingerden, M. M.; Grubbs, R. H. Org. Lett. 2009, 11, $1261-1264$.

(2) Zhou, H.; Wang, Y.-M.; Zhang, W.-Z.; Qu, J.-P.; Lu, X.-B. Green Chem. 2011, $13,644-650$.

(3) Sarmiento, J.; Suarez-Pantiga, S.; Olmos, A.; Varea, T.; Asensio, G. ACS Catal. 2017, 7, 7146-7155.

\section{Characterization of the MCM-41-IPrAuNTf 2 Complex}

SFig. 1 shows low angle XRD patterns of mesoporous MCM-41 and the MCM41-IPrAuNTf $f_{2}$ complex. Low angle XRD pattern of parent MCM-41 material displays an intense $d_{100}$ plane diffraction peak at $2 \theta=2.31$ and two higher order diffraction peaks ( $d_{110}$ and $d_{200}$ planes) with low intensities at $2 \theta=4.02$ and 4.65 , respectively, 
which is due to the hexagonally-ordered mesoporous structure of MCM-41. The MCM-41-IPrAuNTf 2 complex presents a similar XRD pattern to parent MCM-41. However, after grafting the $\operatorname{IPA} A \mathrm{NTf}_{2}$ complexes, the intensities of the $\mathrm{d}_{100}, \mathrm{~d}_{110}$ and $\mathrm{d}_{200}$ plane diffraction peaks decreased markedly, which can be attributed to contrast matching between the silicate framework and the $\operatorname{IPrAuNTf}_{2}$ complex grafted onto the inner channel walls of MCM-41. These results indicate that the ordered mesoporous structure of the starting MCM-41 material is maintained through the grafting $\mathrm{IPrAuNTf}_{2}$ complexes procedure.

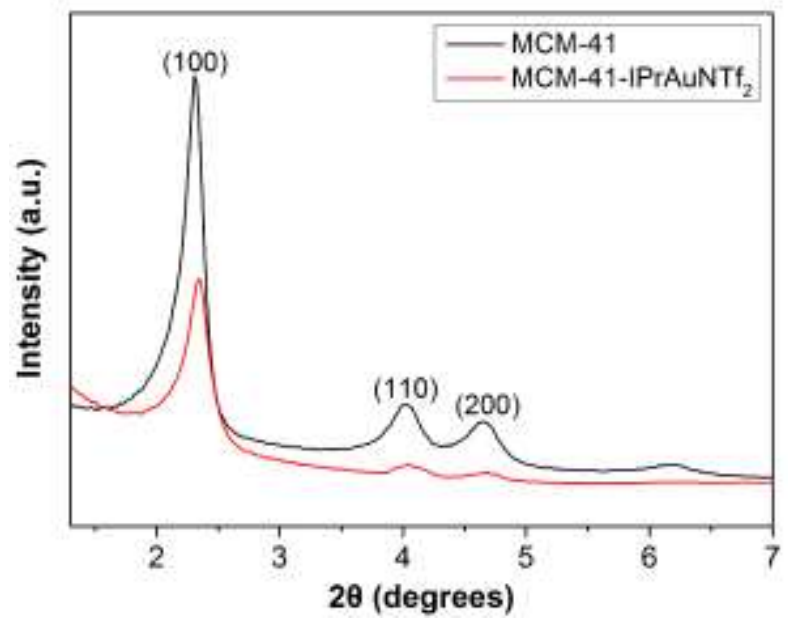

SFig. 1 Low angle XRD patterns of MCM-41 and MCM-41-IPrAuNTf 2.

SFig. 2 displays the $\mathrm{N}_{2}$ adsorption/desorption isotherms of MCM-41-IPrAuNTf 2 and MCM-41 recorded at $77 \mathrm{~K}$. Both parent MCM-41 and the modified MCM-41$\mathrm{IPrAuNTf}_{2}$ materials showed a type IV isotherm (definition by IUPAC), which is a typical feature for the porous materials having average pore diameters ranged from 2 to $50 \mathrm{~nm}$. However, compared to parent MCM-41, MCM-41-IPrAuNTf 2 exhibits an obviously decreased uptake of $\mathrm{N}_{2}$ because of the incorporation of the $\operatorname{IPrAuNTf}_{2}$ complexes into the inner channels of MCM-41. The pore size distribution profiles of MCM-41 and MCM-41-IPrAuNTf 2 are presented in SFig. 3. In contrast to MCM-41, both average pore diameter and pore volume of MCM-41-IPrAuNTf 2 decreased markedly, also verifying that the $\operatorname{IPrAuNTf}_{2}$ complexes were successfully grafted onto the inner channel walls of MCM-41, but a narrow pore size distribution is still 
observed. After grafting the $\operatorname{IPrAuNTf}_{2}$ complexes, the average pore diameter and BET specific surface area of MCM-41 were reduced from $2.7 \mathrm{~nm}$ and $1021 \mathrm{~m}^{2} / \mathrm{g}$ to $1.7 \mathrm{~nm}$ and $517 \mathrm{~m}^{2} / \mathrm{g}$, respectively, which further indicating that the ordered mesoporous structure of the starting MCM-41 material was not damaged during the preparation of MCM-41-IPrAuNTf 2 .

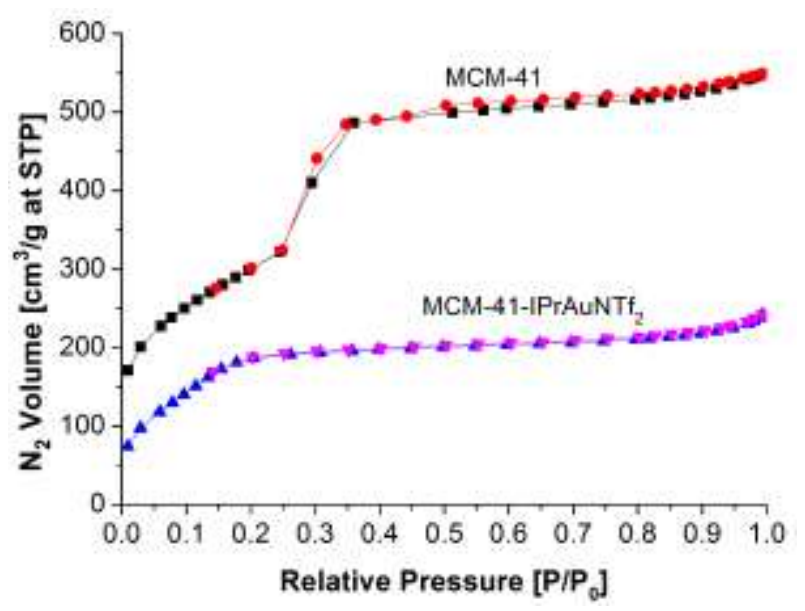

SFig. $2 \mathrm{~N}_{2}$ adsorption/desorption isotherms of MCM-41 and MCM-41-IPrAuNTf 2.

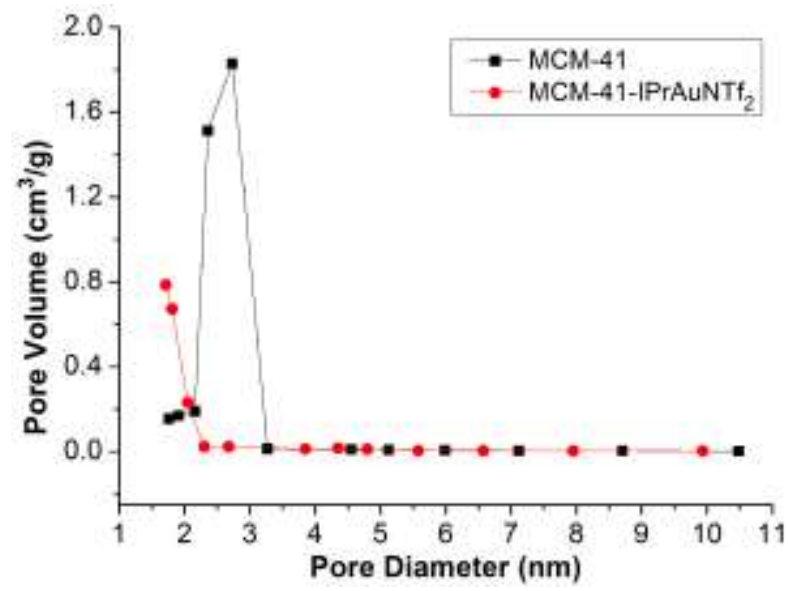

SFig. 3 Pore size distributions of MCM-41 and MCM-41-IPrAuNTf 2 .

The MCM-41-IPrAuNTf 2 complex was further characterized by X-ray photoelectron spectroscopy (XPS). The XPS spectrum of MCM-41-IPrAuNTf 2 (SFig. 4) exhibits the spin orbit pair at $85.0 \mathrm{eV}$ for $\mathrm{Au} 4 \mathrm{f}^{7 / 2}$ and $88.6 \mathrm{eV}$ for $\mathrm{Au} 4 \mathrm{f}^{5 / 2}$, which verifying that the oxidation state of gold in MCM-41-IPrAuNTf $f_{2}$ was $\mathrm{Au}(\mathrm{I})$. The energy dispersive X-ray spectroscopy (EDS) is usually used to analyze the elemental 
components of the material. From SFig. 5 it can be seen that the modified MCM-41$\mathrm{IPrAuNTf}_{2}$ material contains $\mathrm{C}, \mathrm{N}, \mathrm{O}, \mathrm{Si}, \mathrm{F}, \mathrm{S}$, and Au elements, indicating that the $\mathrm{IPrAuNTf}_{2}$ complexes have been successfully anchored onto MCM-41.

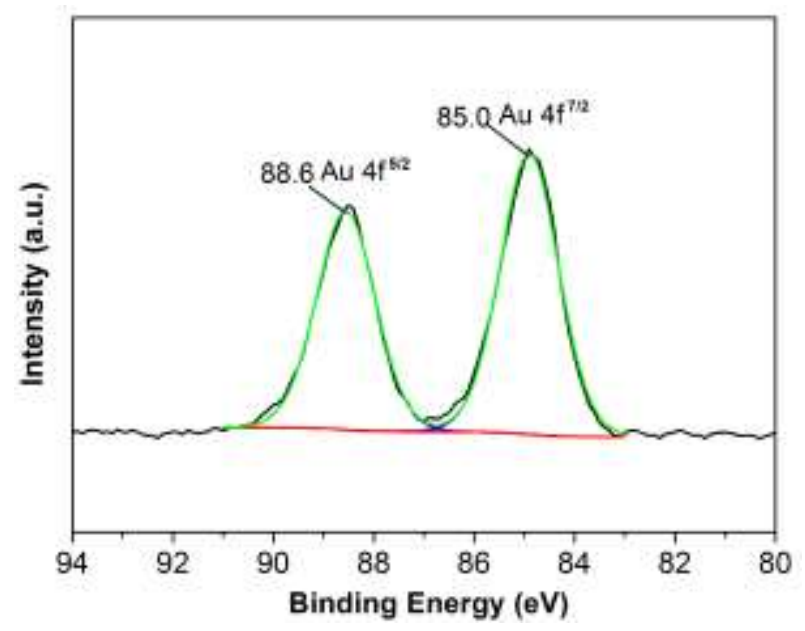

SFig. 4 XPS spectrum of MCM-41-IPrAuNTf 2.

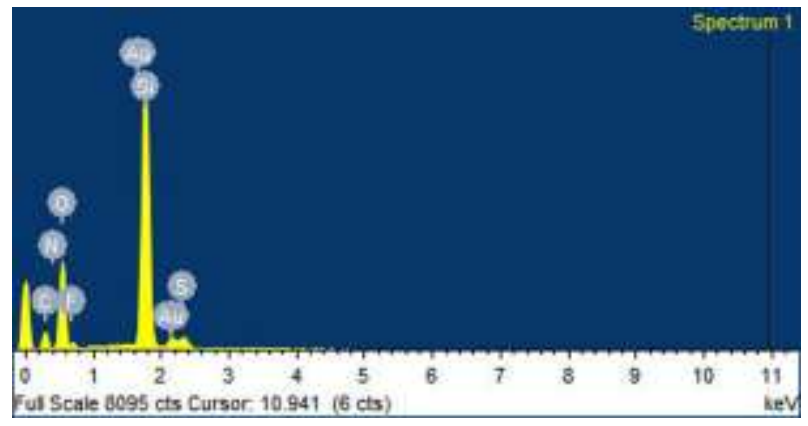

SFig. 5 Energy dispersive spectrum (EDS) of MCM-41-IPrAuNTf 2.

SFig. 6 displays SEM images of fresh MCM-41-IPrAuNTf 2 complex and the recovered gold(I) catalyst after the eighth cycle. According to the SEM image (6a) of fresh MCM-41-IPrAuNTf 2 complex, nanoparticles were made up of quite homogeneous and uniform spherical particles. As seen in SFig. 6b, no significant changes in the morphology occurred after the catalyst being recycled for eight times. The TEM images of fresh MCM-41-IPrAuNTf 2 complex and the recovered gold(I) catalyst after the eighth cycle are shown in SFig. 7. The highly ordered structure with a hexagonal ordered porous parallel channels can be clearly observed from SFig. 7a. Also it can be 
founded that the recycling of the catalyst did not cause a significant damage to the ordered mesoporous structure of the MCM-41 support from SFig. 7b.

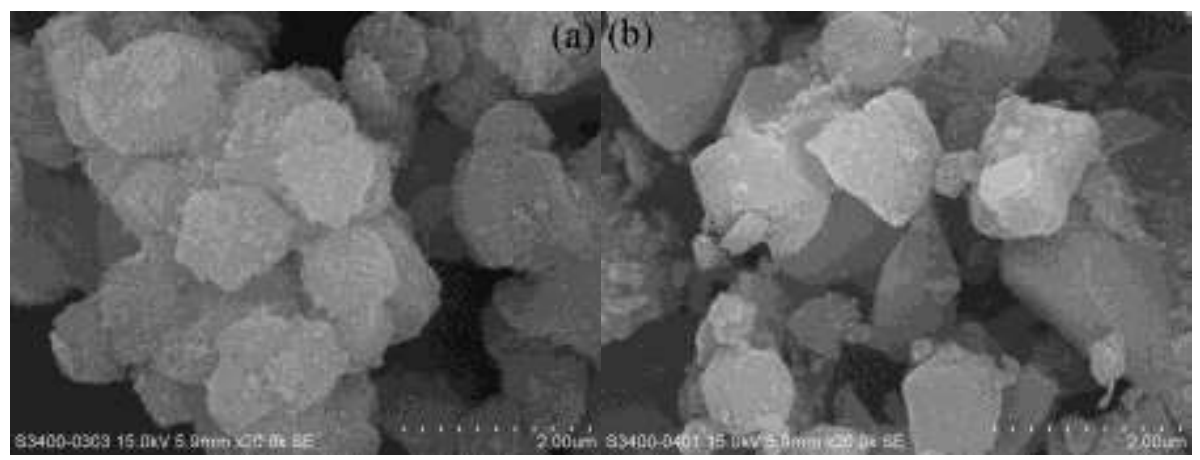

SFig. 6 SEM images of fresh MCM-41-IPrAuNTf 2 complex (a) and the recovered gold(I) catalyst (b).

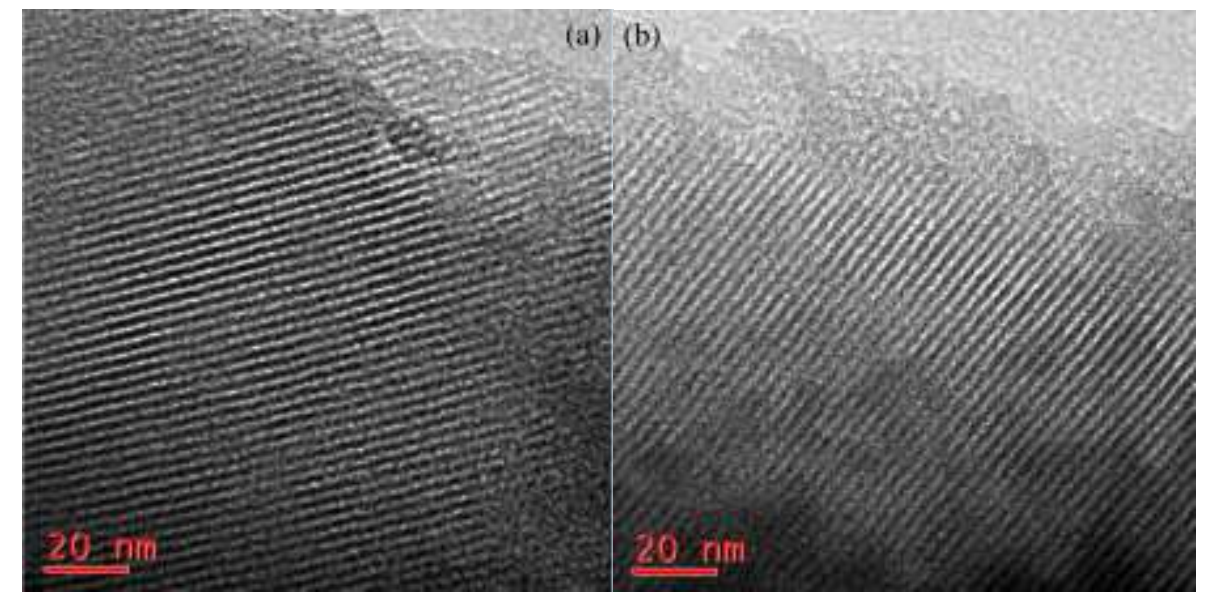

SFig. 7 TEM images of fresh MCM-41-IPrAuNTf 2 complex (a) and the recovered gold(I) catalyst (b). 
3. NMR Spectra of Compounds 3a-r, 5a-p and 7a-f 


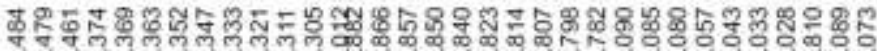

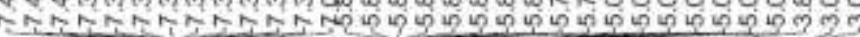
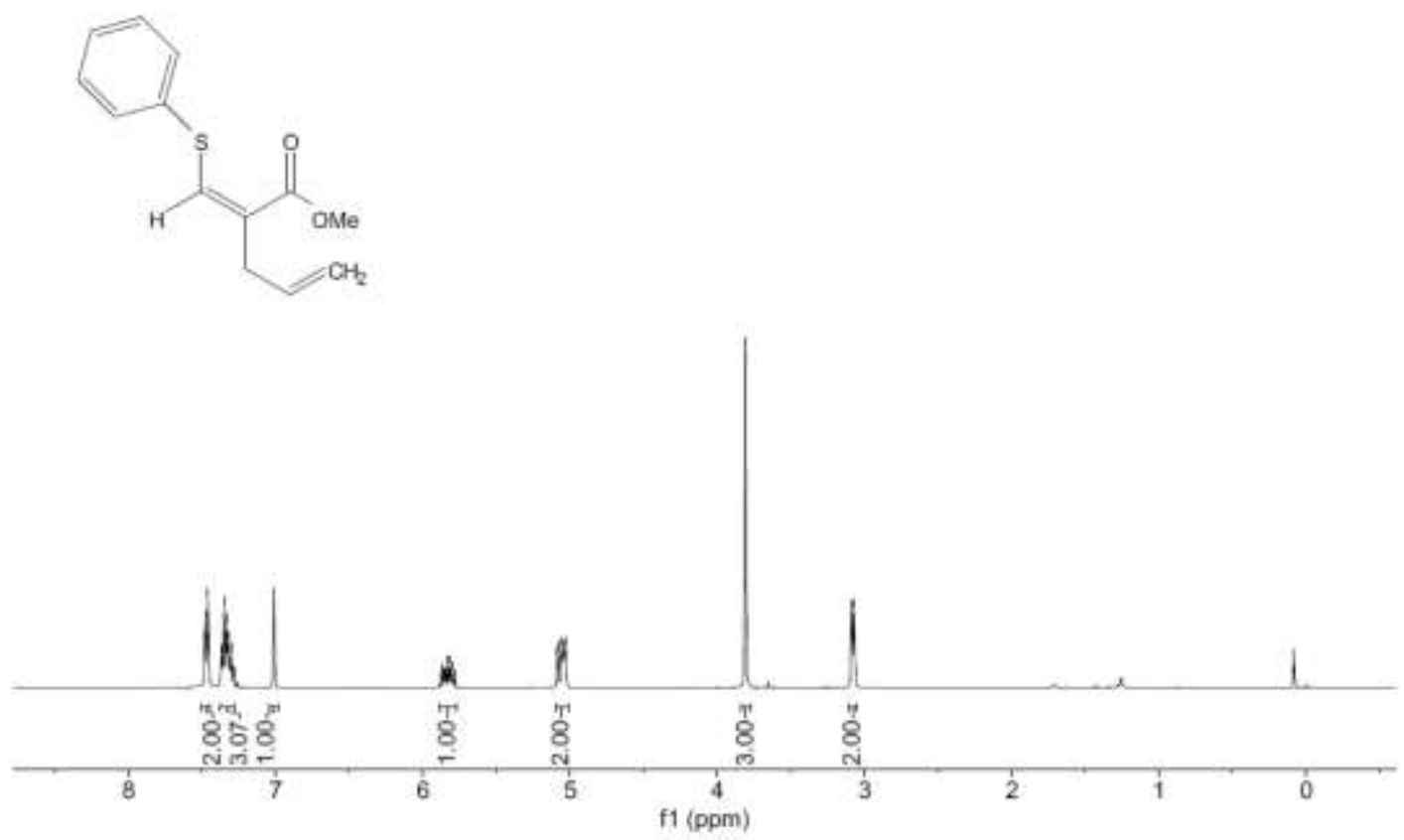

\begin{tabular}{|c|c|c|c|}
\hline $\begin{array}{l}\frac{9}{6} \\
\frac{9}{9} \\
\frac{1}{1}\end{array}$ & 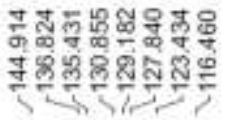 & 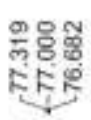 & $\frac{4}{8}$ \\
\hline
\end{tabular}
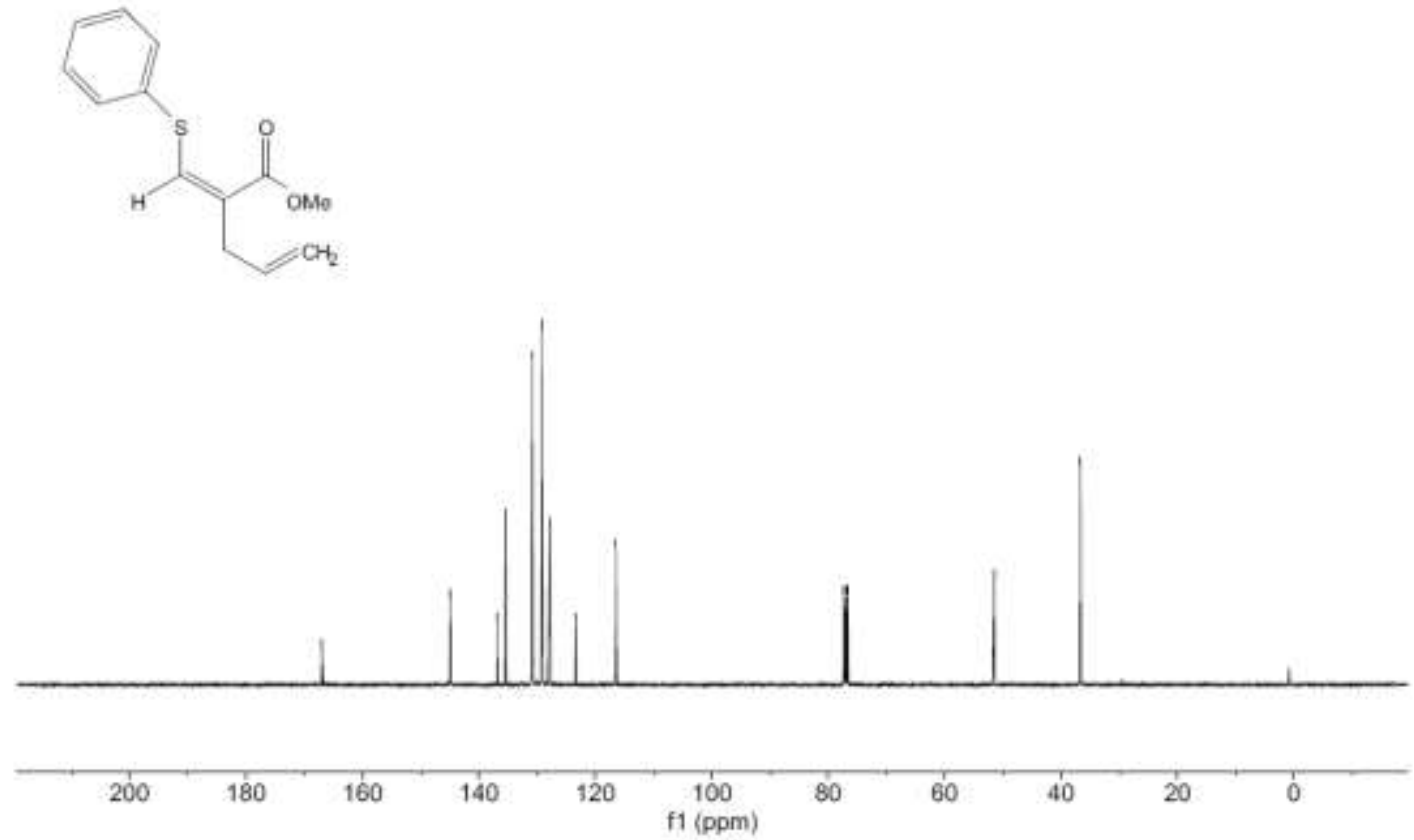

${ }^{1} \mathrm{H}$ NMR (400 MHz) and ${ }^{13} \mathrm{C}\left\{{ }^{1} \mathrm{H}\right\}$ NMR (100 MHz) spectra of 3a in $\mathrm{CDCl}_{3}$ 


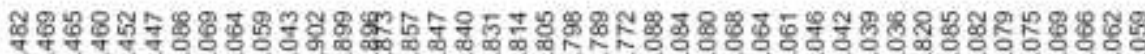

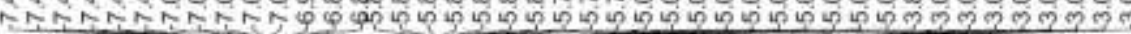
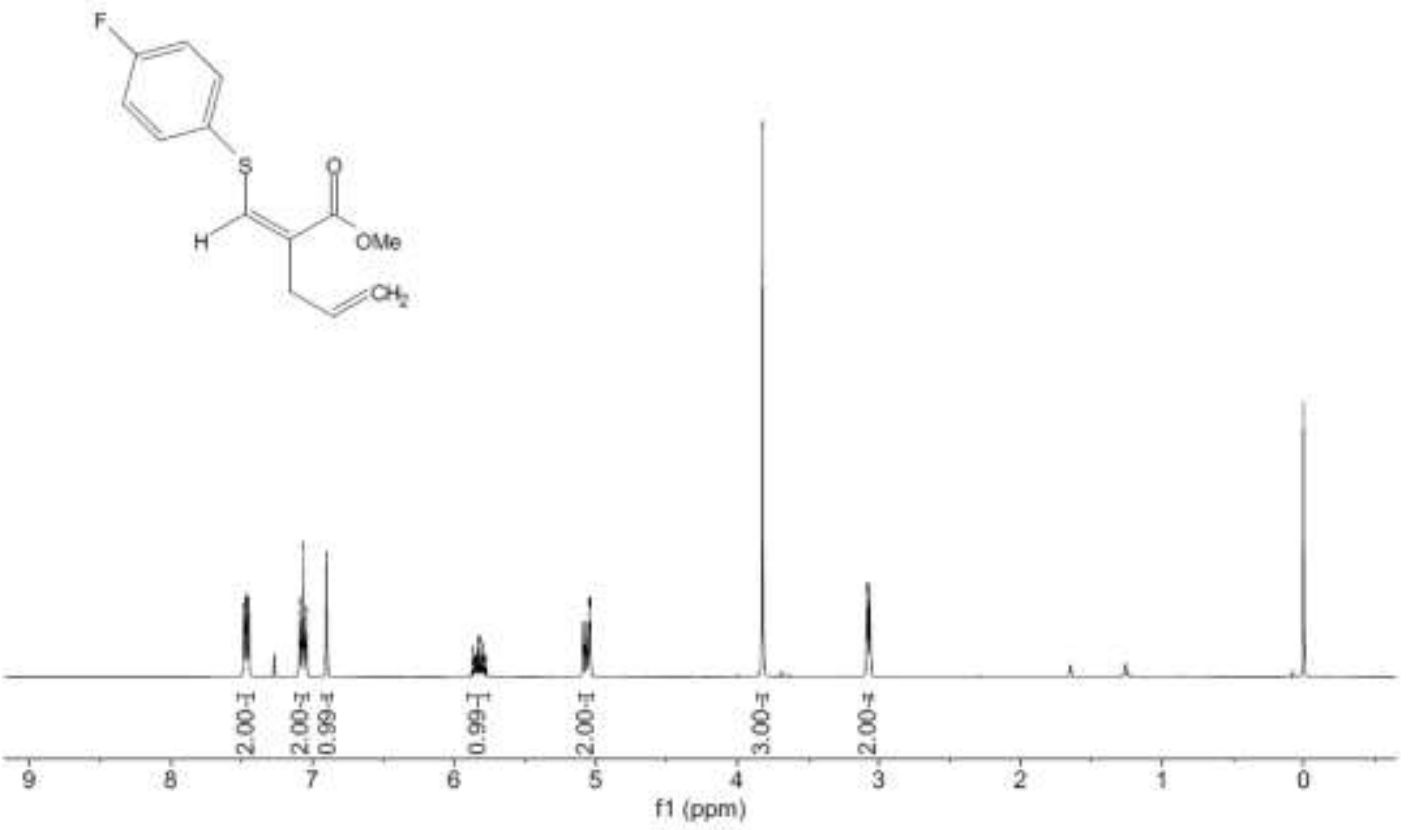

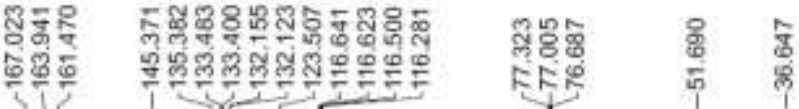
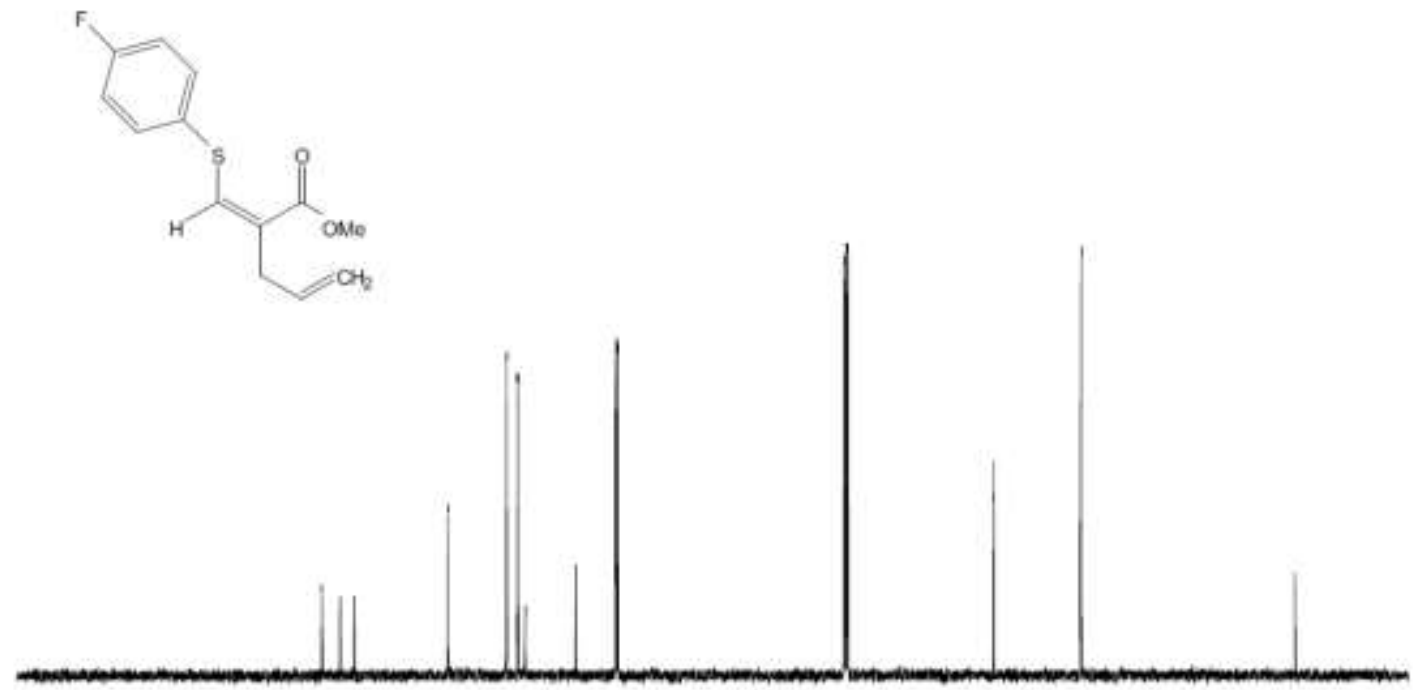

200

180

160

140

120

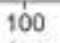

80

60

40

20

${ }^{1} \mathrm{H}$ NMR (400 MHz) and ${ }^{13} \mathrm{C}\left\{{ }^{1} \mathrm{H}\right\}$ NMR (100 MHz) spectra of $\mathbf{3 b}$ in $\mathrm{CDCl}_{3}$ 

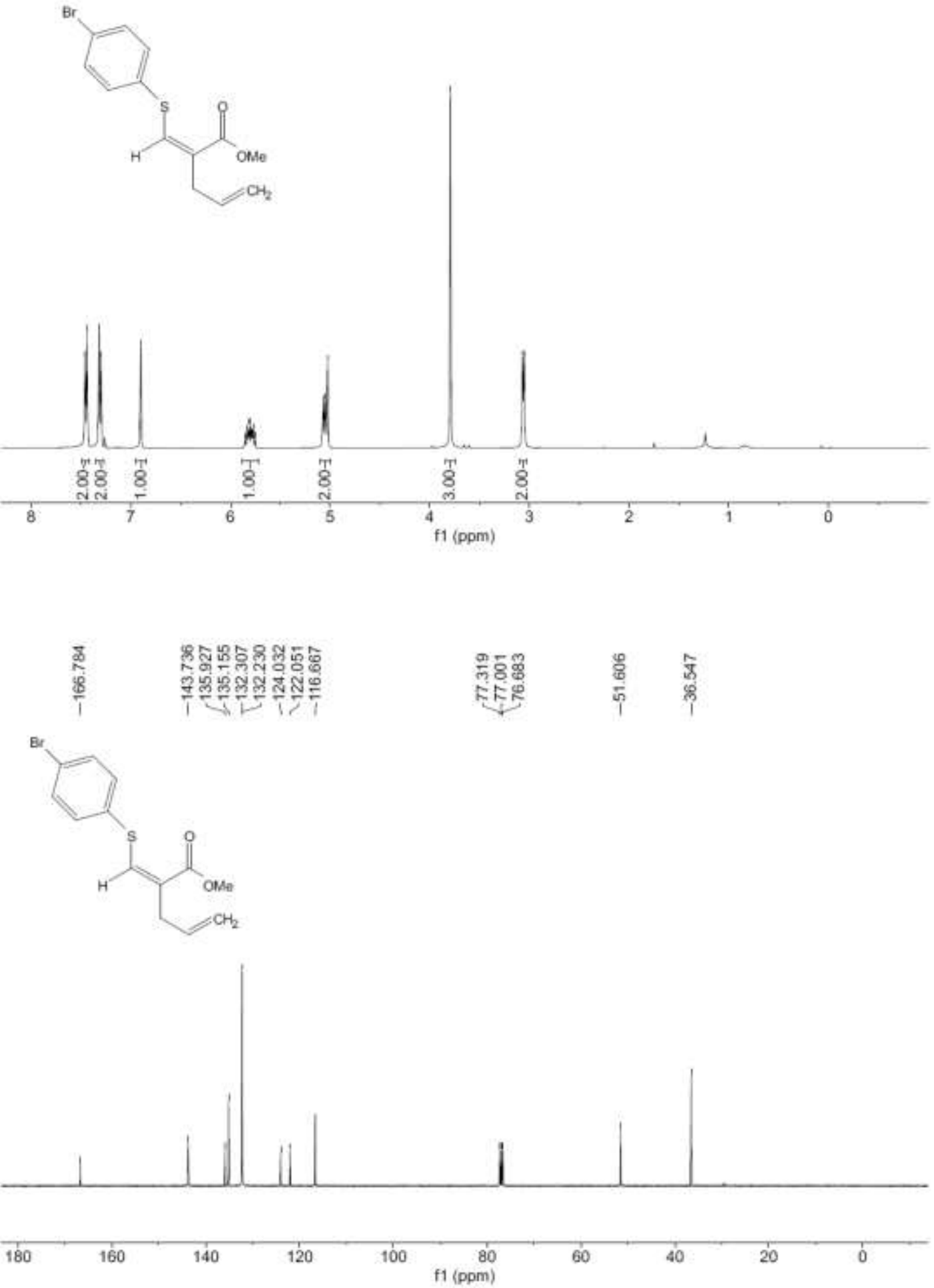

${ }^{1} \mathrm{H}$ NMR $(400 \mathrm{MHz})$ and ${ }^{13} \mathrm{C}\left\{{ }^{1} \mathrm{H}\right\}$ NMR $(100 \mathrm{MHz})$ spectra of $3 \mathbf{c}$ in $\mathrm{CDCl}_{3}$ 


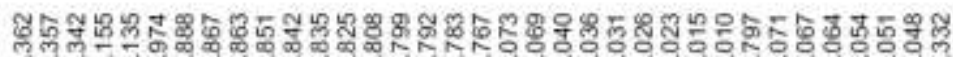

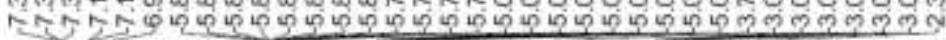
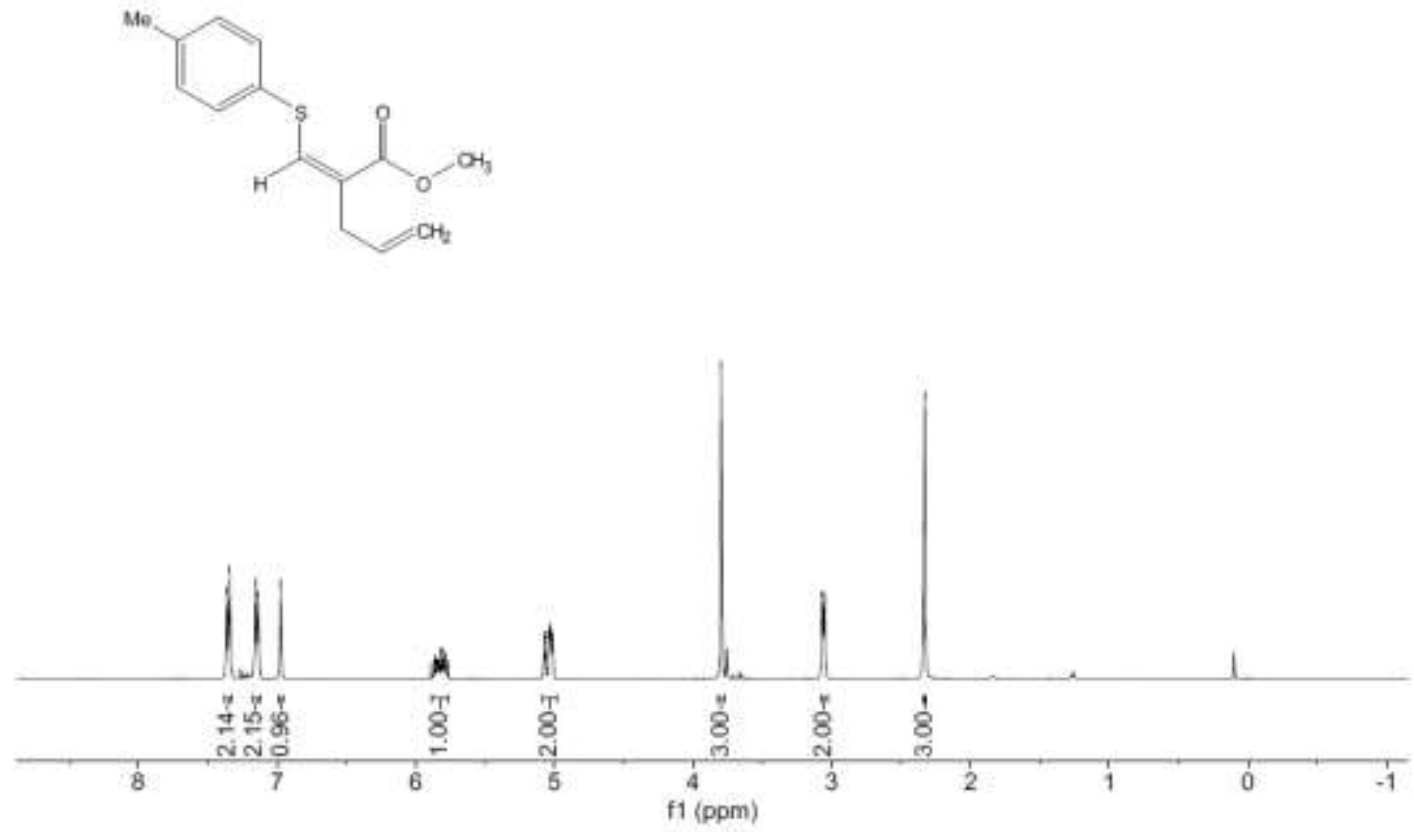

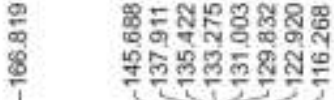

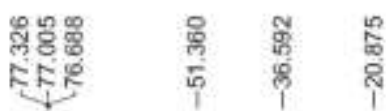

Mk.<smiles>C=CC/C(=C\Sc1ccc(Br)cc1)C(=O)OC</smiles>

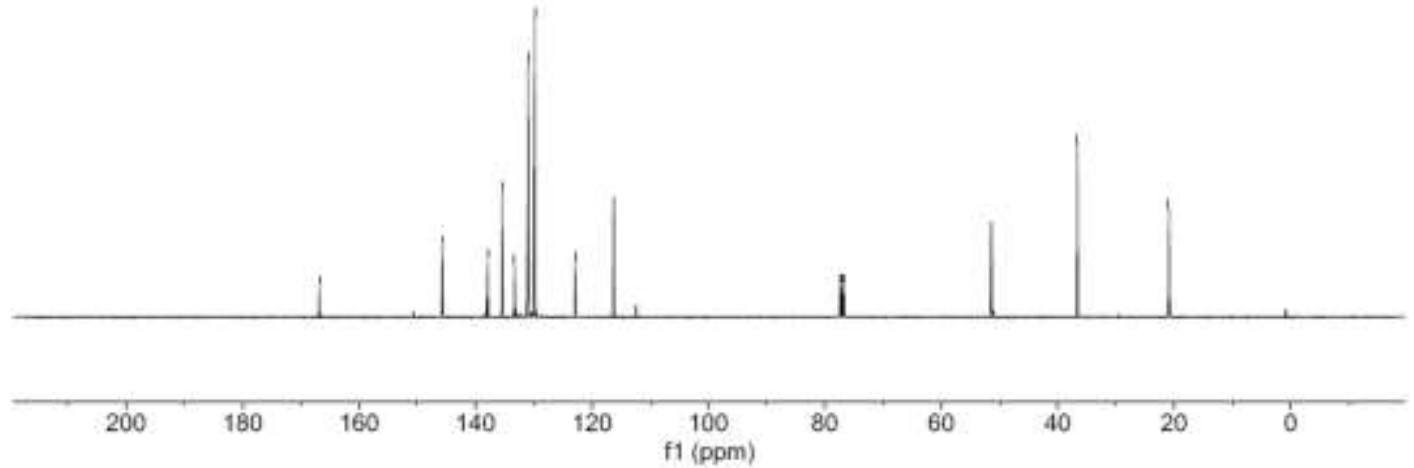

${ }^{1} \mathrm{H}$ NMR (400 MHz) and ${ }^{13} \mathrm{C}\left\{{ }^{1} \mathrm{H}\right\}$ NMR (100 MHz) spectra of $\mathbf{3 d}$ in $\mathrm{CDCl}_{3}$ 

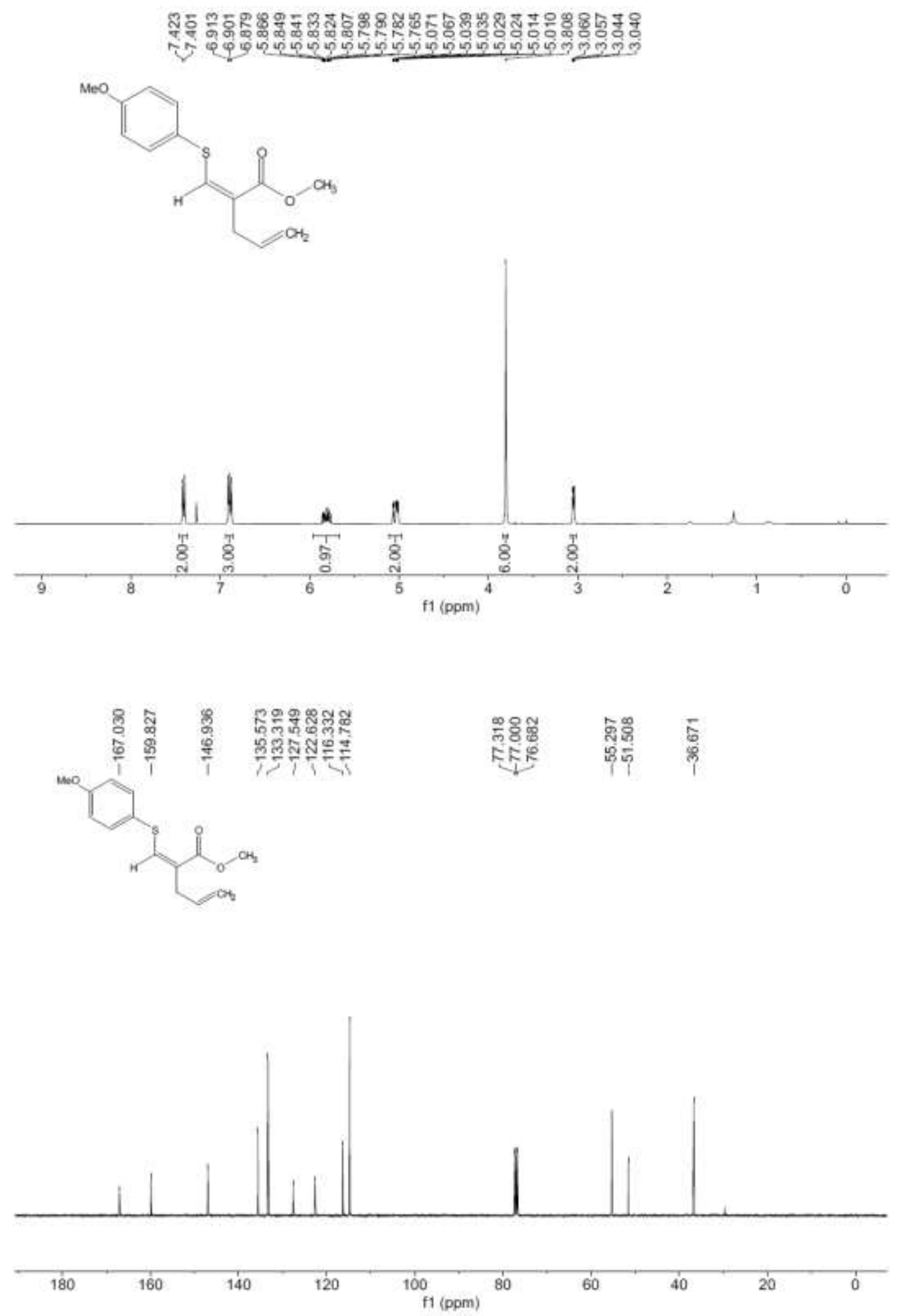

${ }^{1} \mathrm{H}$ NMR (400 MHz) and ${ }^{13} \mathrm{C}\left\{{ }^{1} \mathrm{H}\right\}$ NMR $(100 \mathrm{MHz})$ spectra of $3 \mathbf{e}$ in $\mathrm{CDCl}_{3}$ 


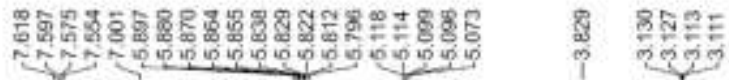
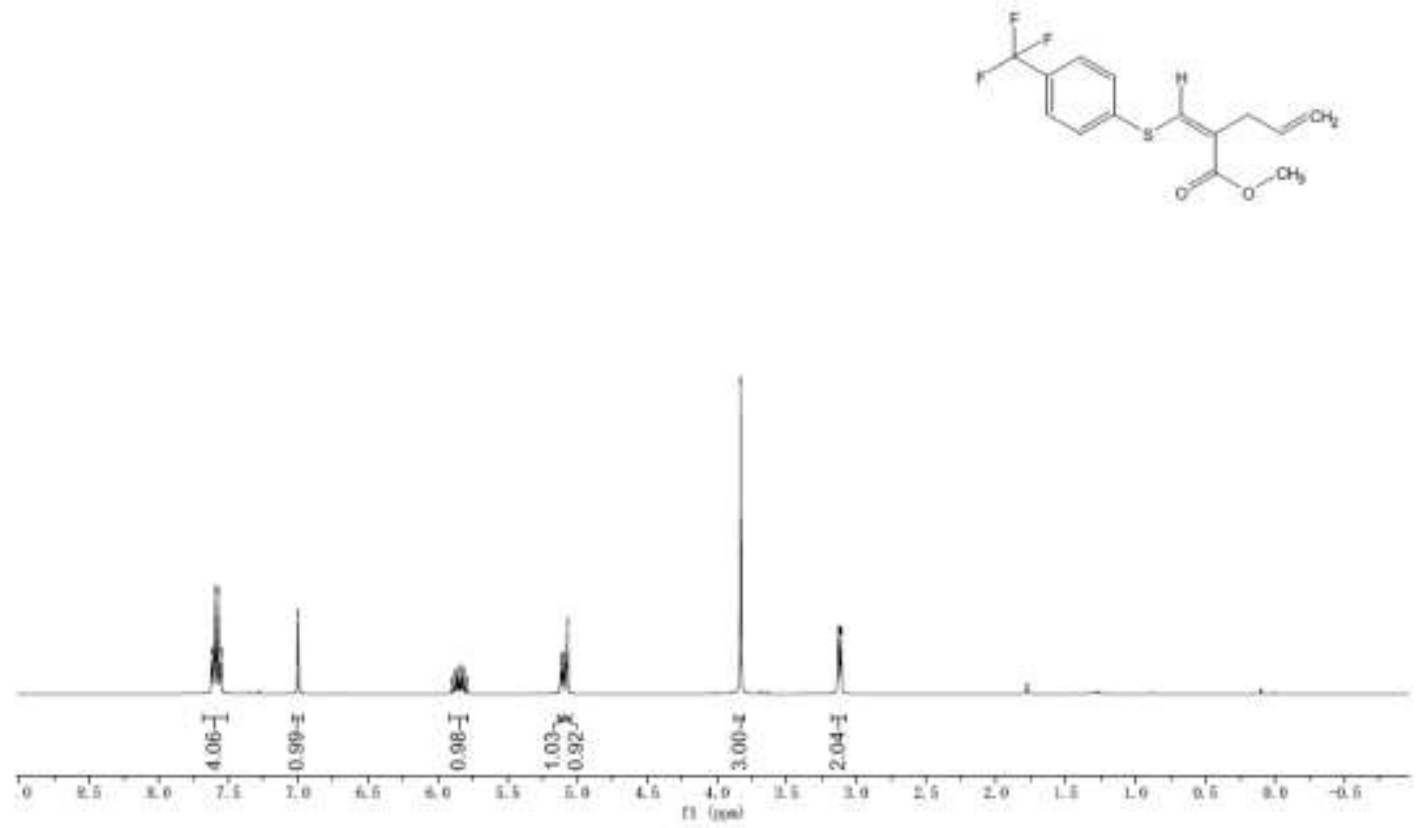

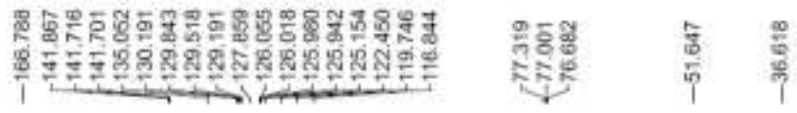
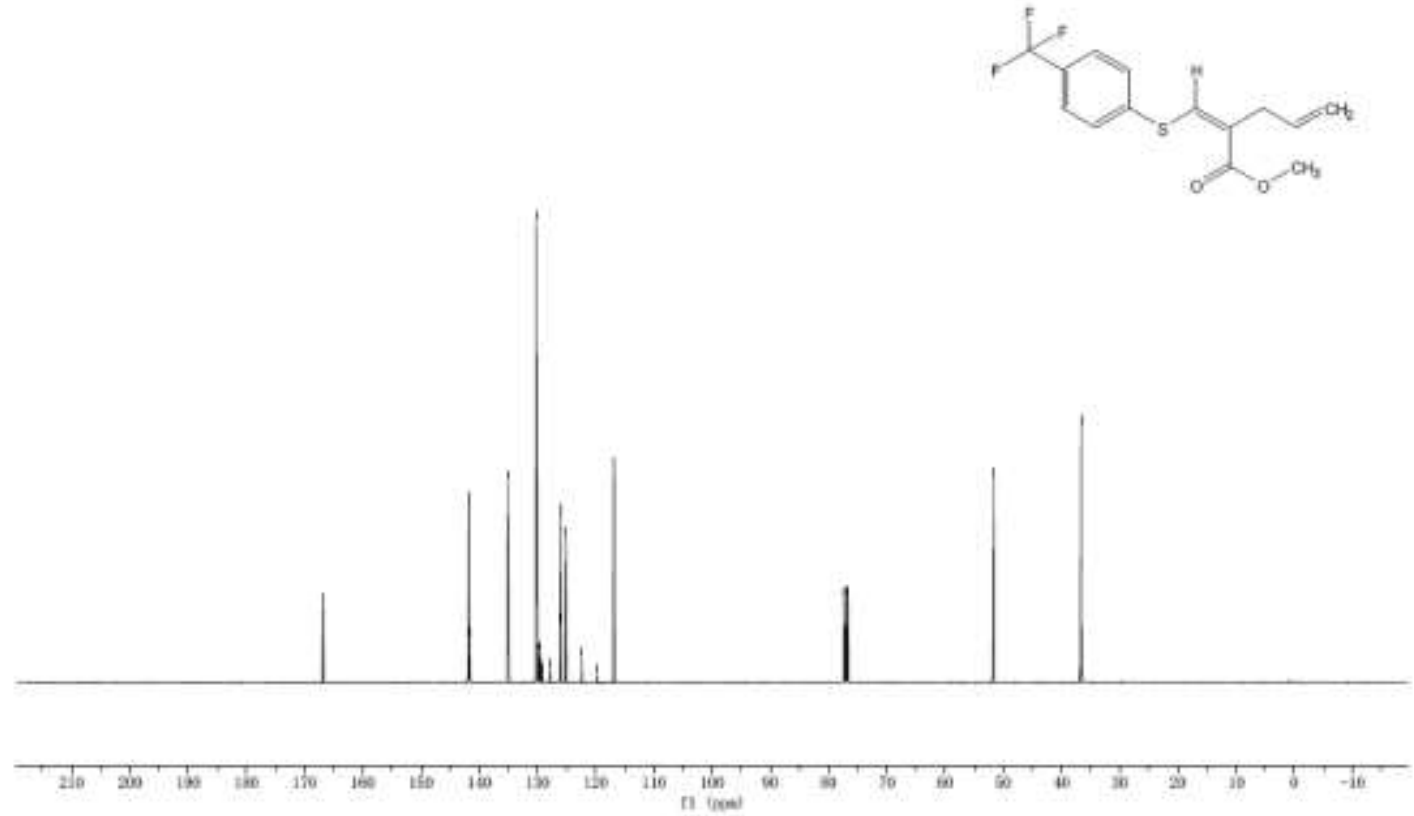

${ }^{1} \mathrm{H}$ NMR $(400 \mathrm{MHz})$ and ${ }^{13} \mathrm{C}\left\{{ }^{1} \mathrm{H}\right\}$ NMR $(100 \mathrm{MHz})$ spectra of $\mathbf{3 f}$ in $\mathrm{CDCl}_{3}$ 

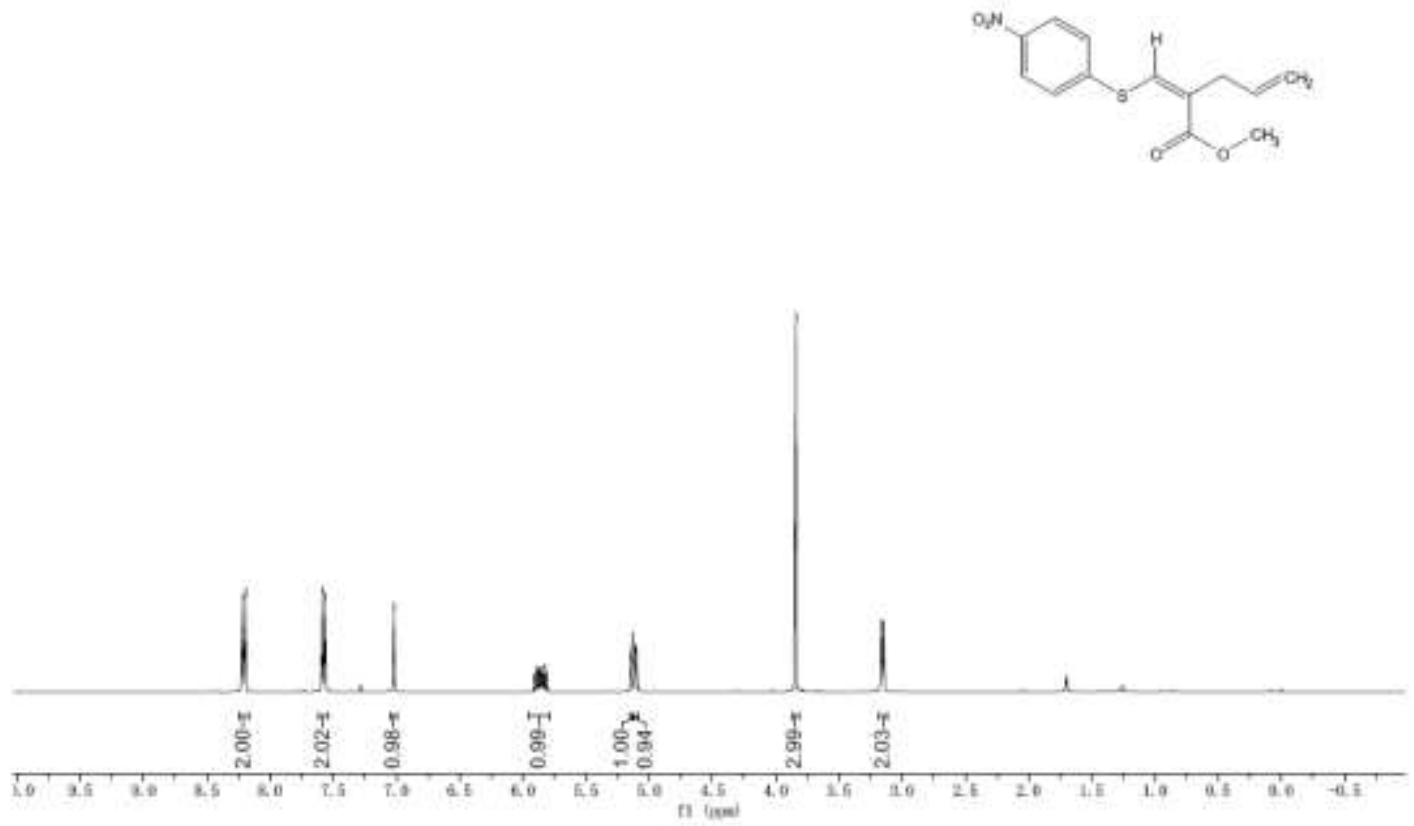

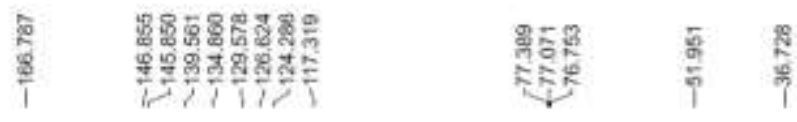
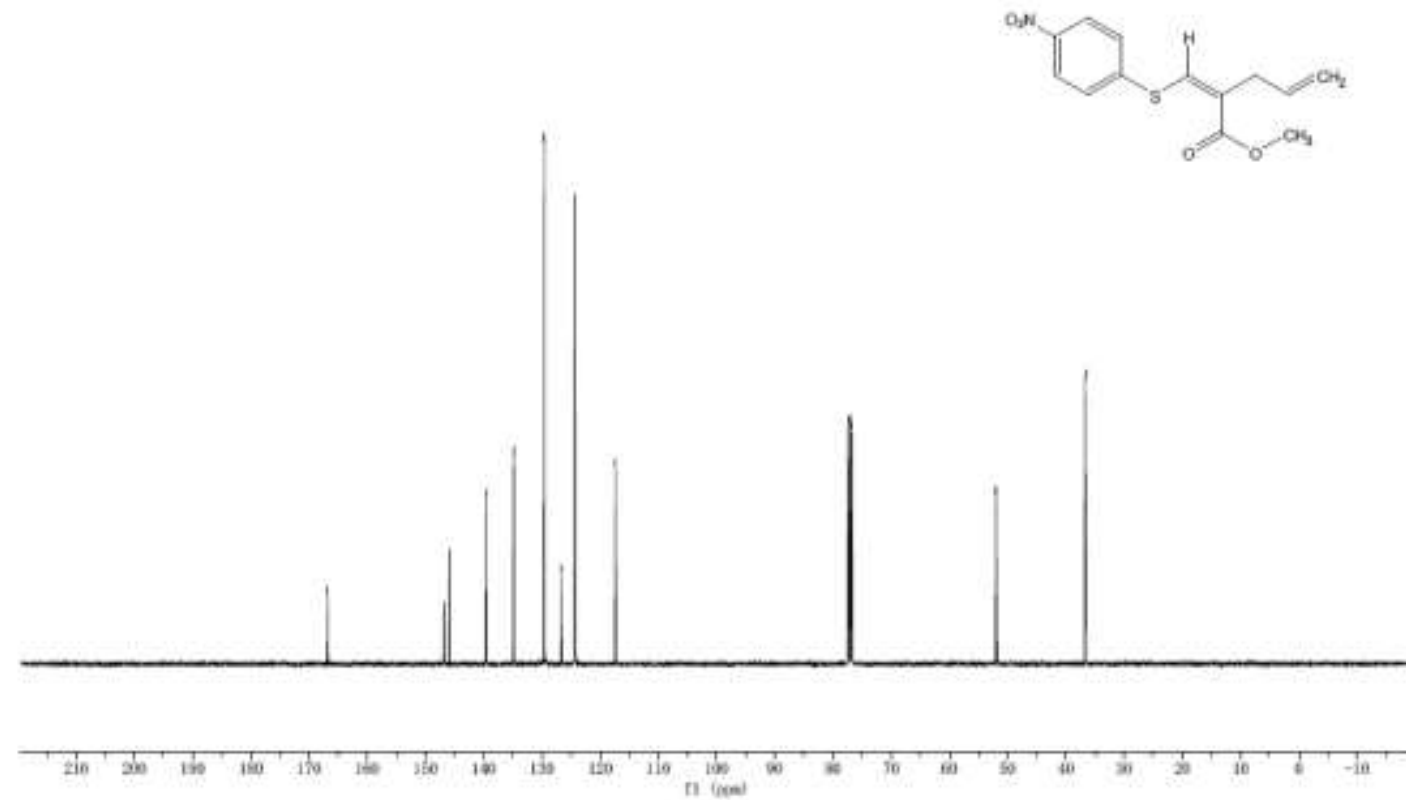

${ }^{1} \mathrm{H}$ NMR (400 MHz) and ${ }^{13} \mathrm{C}\left\{{ }^{1} \mathrm{H}\right\}$ NMR (100 MHz) spectra of $\mathbf{3 g}$ in $\mathrm{CDCl}_{3}$ 


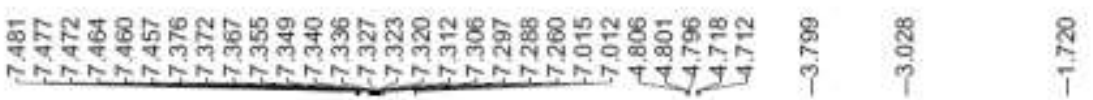<smiles>[2H]C(OC)/C(=C\Sc1ccccc1)CC(=O)O</smiles>
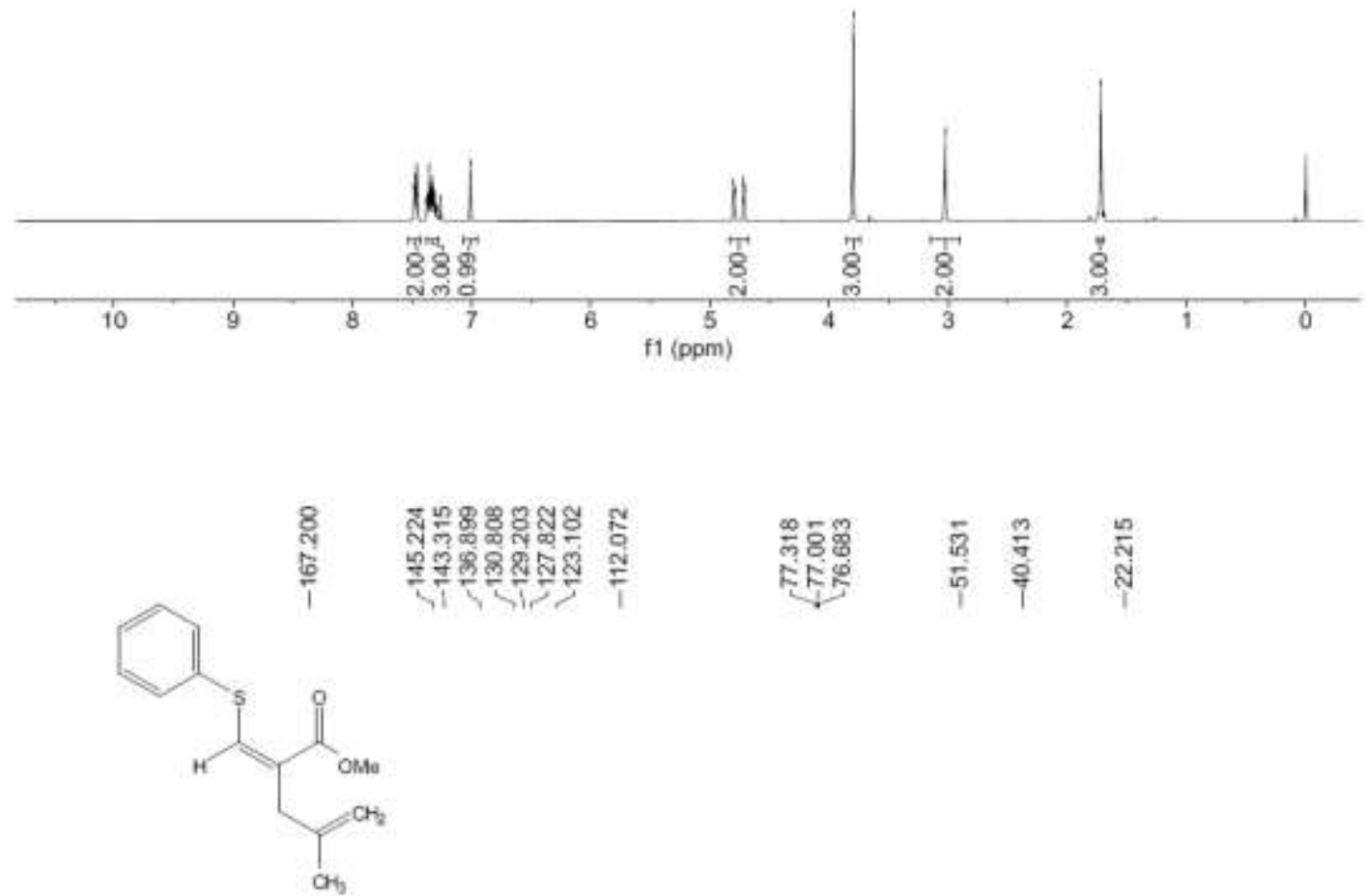

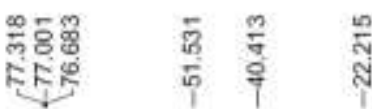

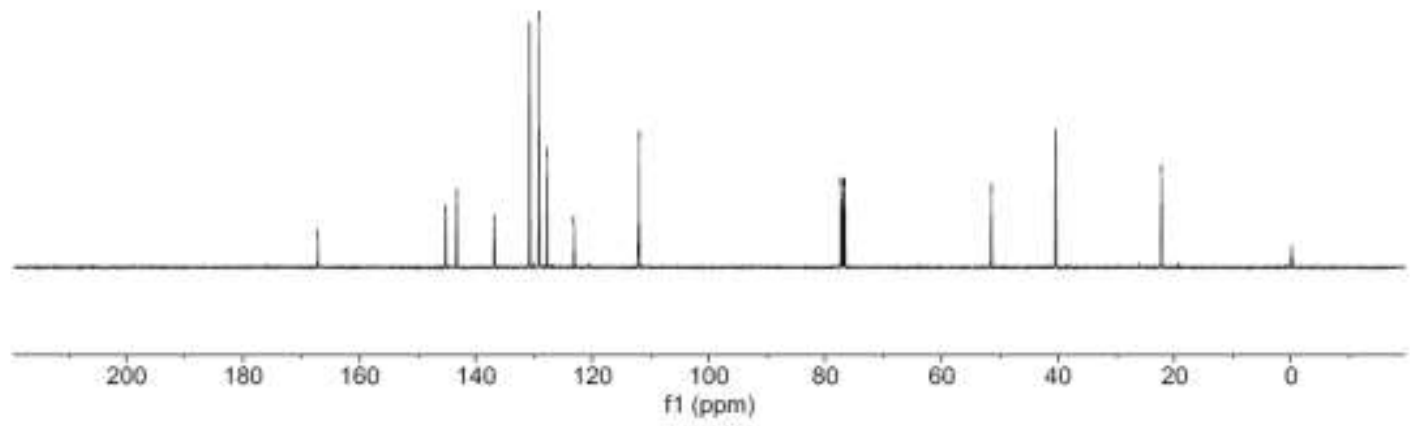

${ }^{1} \mathrm{H}$ NMR (400 MHz) and ${ }^{13} \mathrm{C}\left\{{ }^{1} \mathrm{H}\right\}$ NMR (100 MHz) spectra of $\mathbf{3 h}$ in $\mathrm{CDCl}_{3}$ 

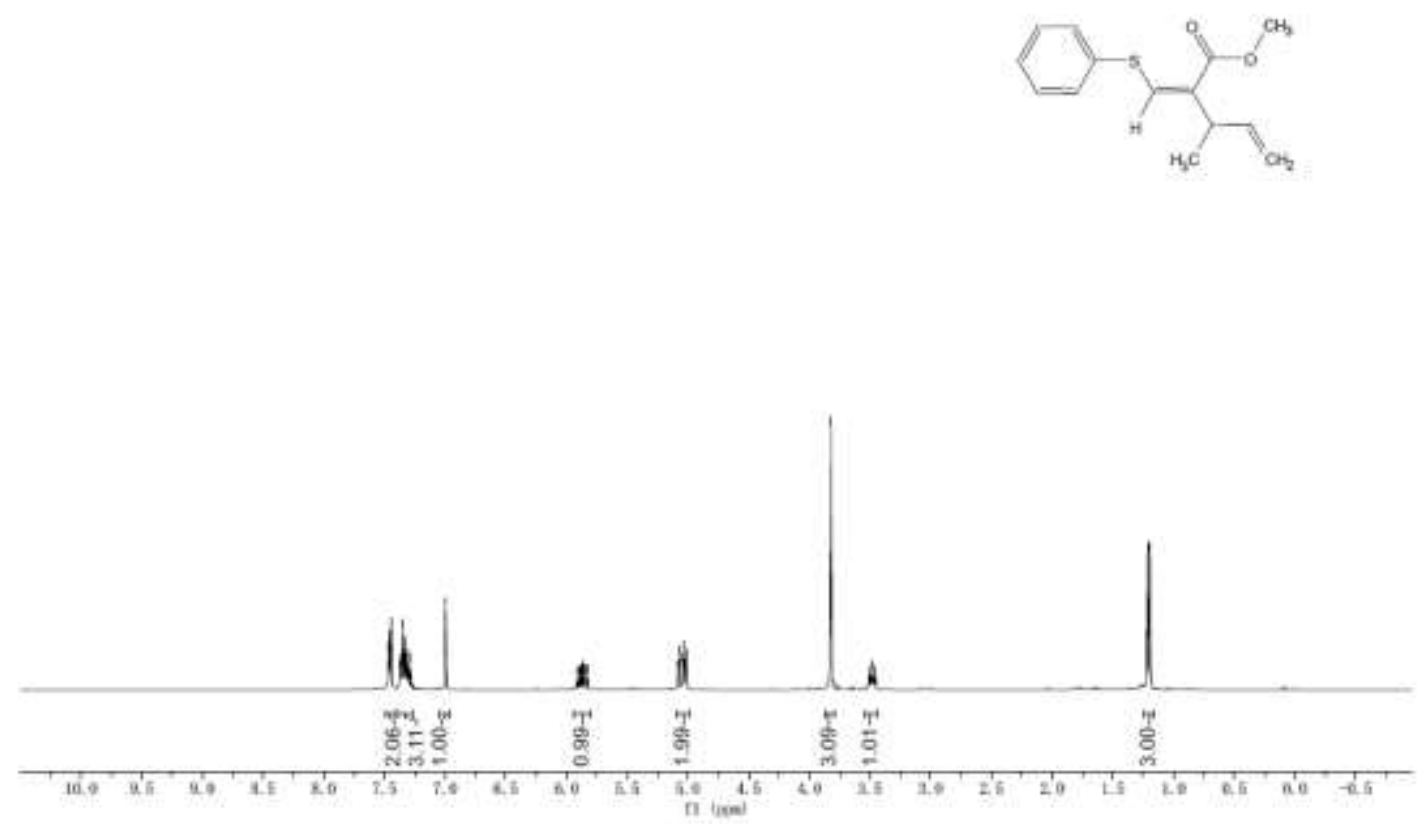

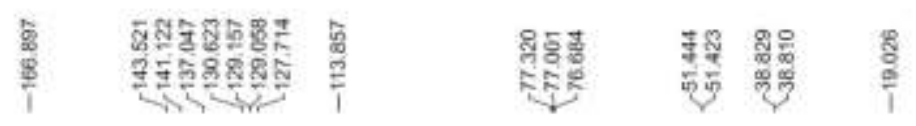
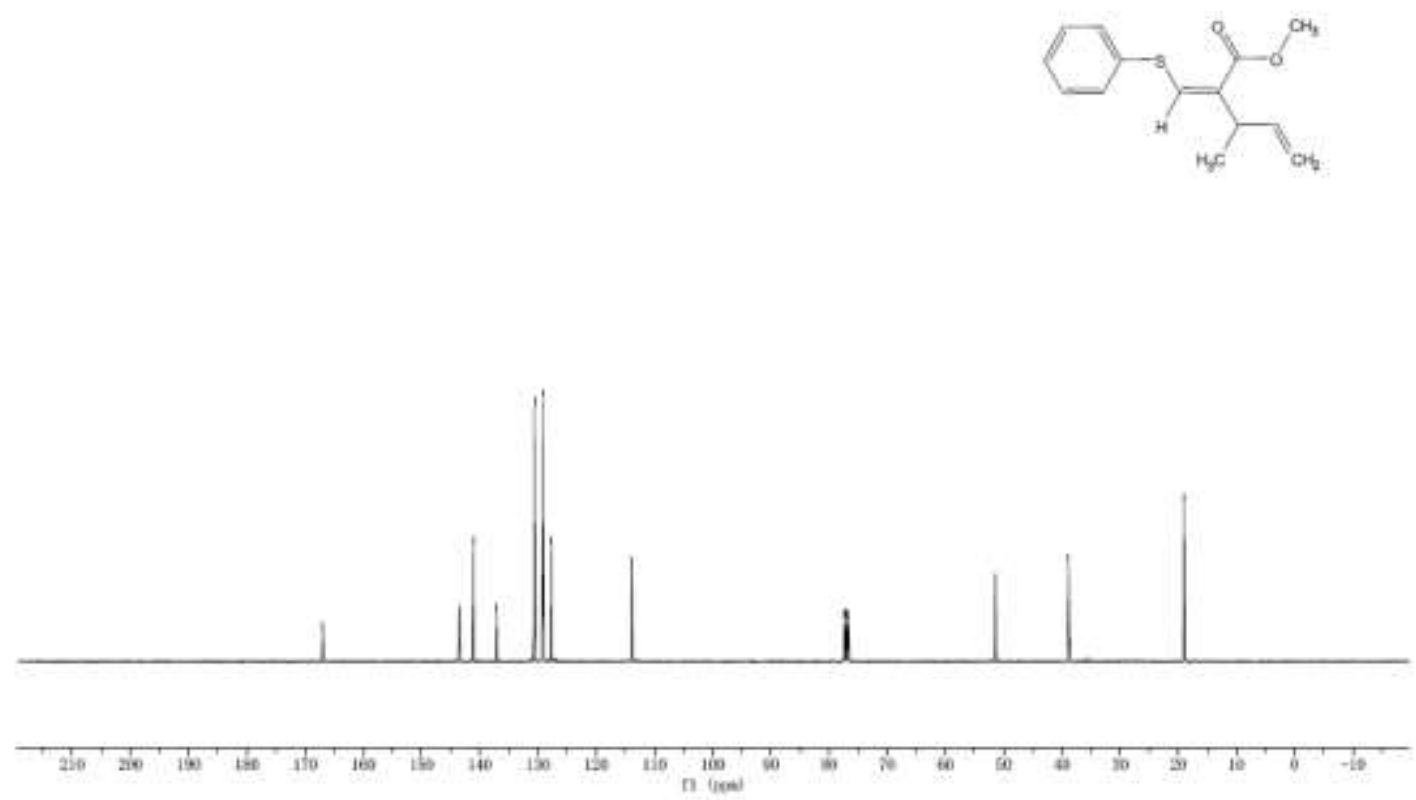

${ }^{1} \mathrm{H}$ NMR (400 MHz) and ${ }^{13} \mathrm{C}\left\{{ }^{1} \mathrm{H}\right\}$ NMR (100 MHz) spectra of $3 \mathbf{i}$ in $\mathrm{CDCl}_{3}$ 


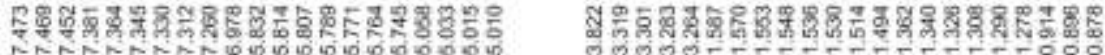

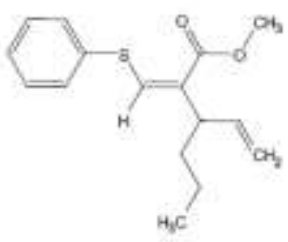

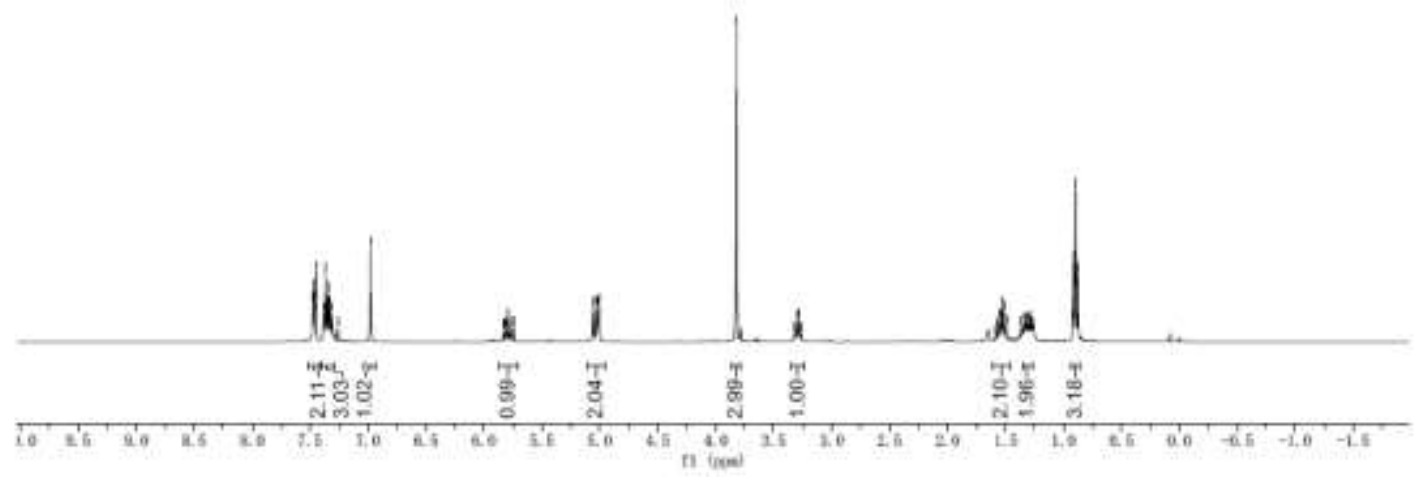

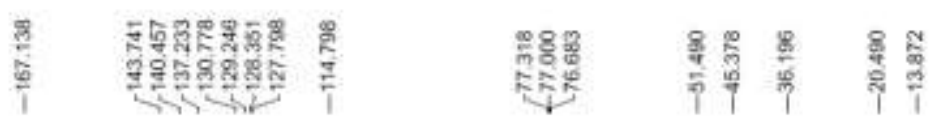
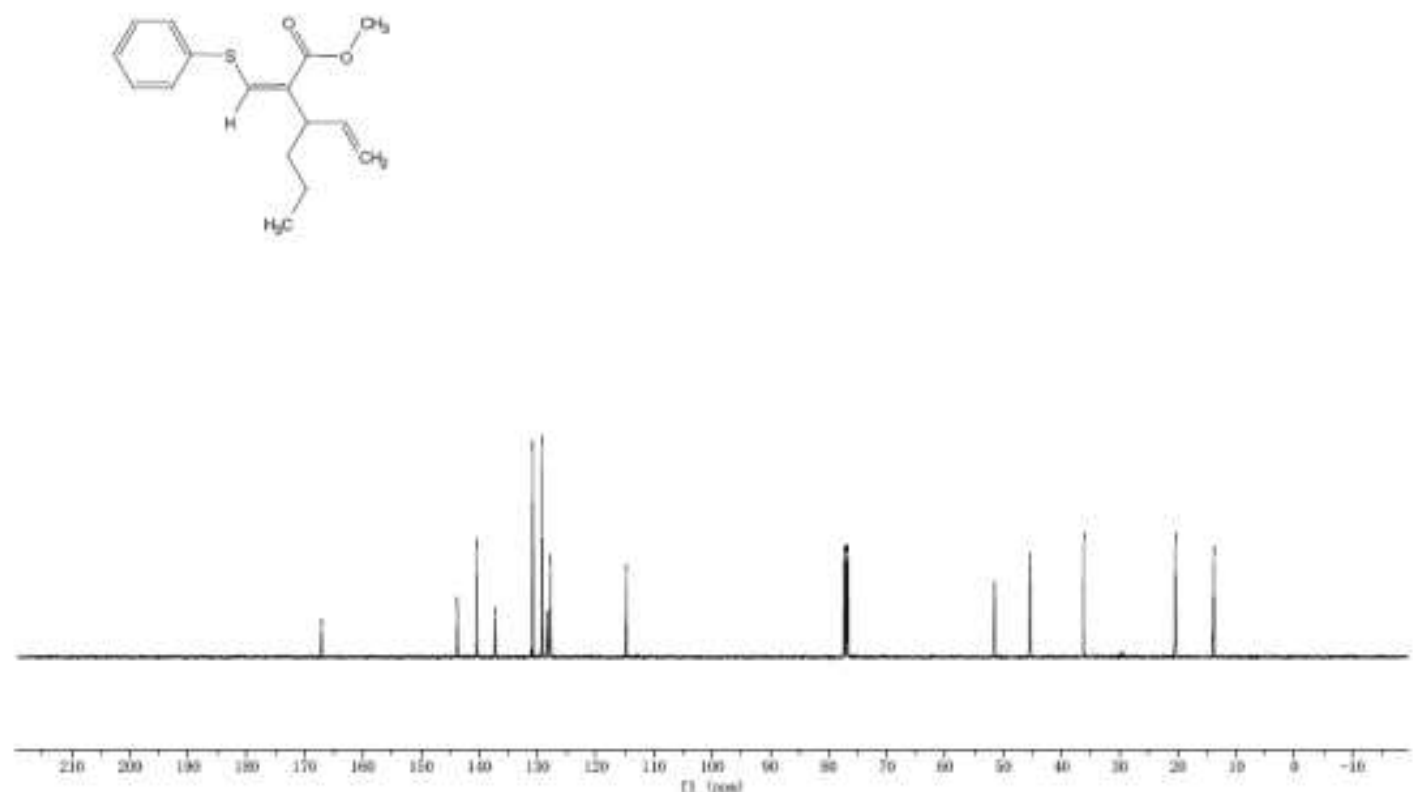

${ }^{1} \mathrm{H}$ NMR (400 MHz) and ${ }^{13} \mathrm{C}\left\{{ }^{1} \mathrm{H}\right\}$ NMR $(100 \mathrm{MHz})$ spectra of $\mathbf{3 j}$ in $\mathrm{CDCl}_{3}$ 

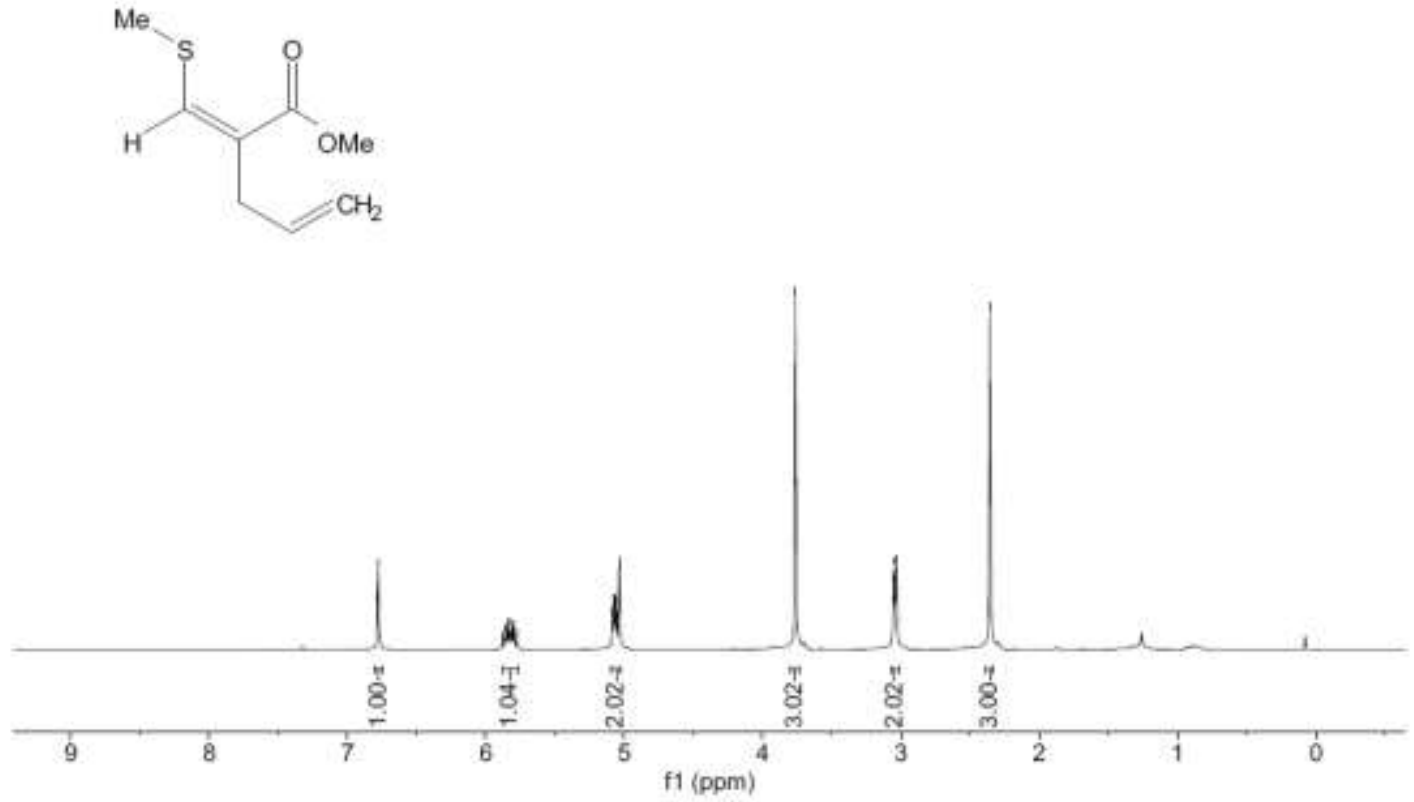<smiles>C=CC/C(=C\SC)C(=O)OC</smiles>

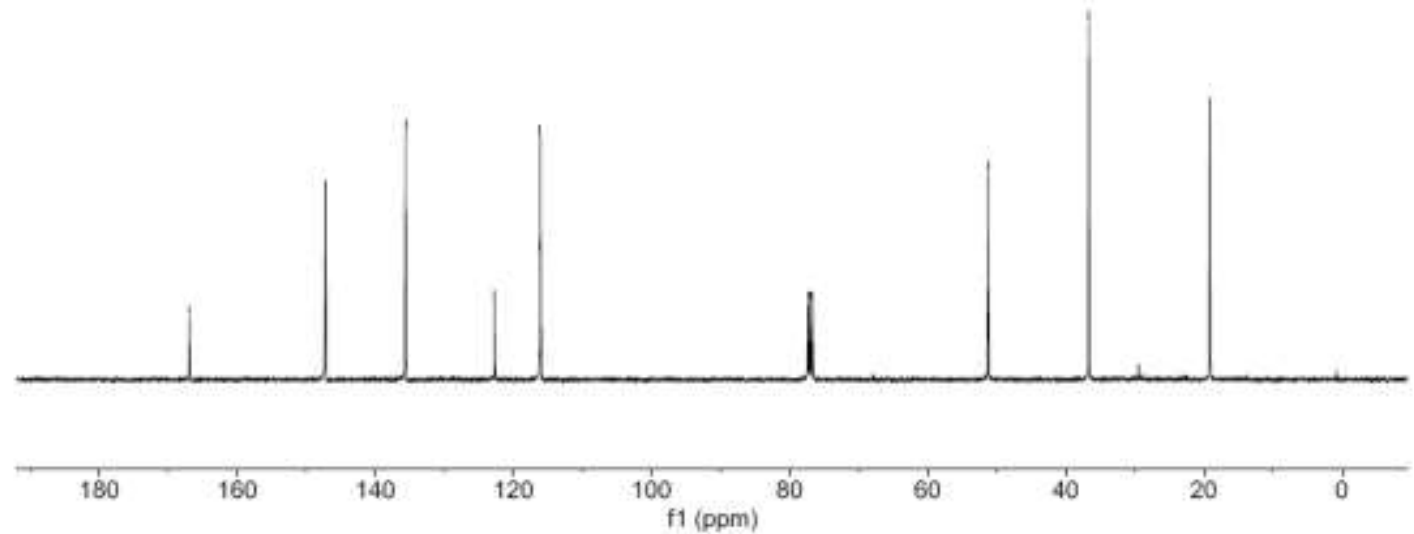

${ }^{1} \mathrm{H}$ NMR (400 MHz) and ${ }^{13} \mathrm{C}\left\{{ }^{1} \mathrm{H}\right\}$ NMR (100 MHz) spectra of 3k in $\mathrm{CDCl}_{3}$ 

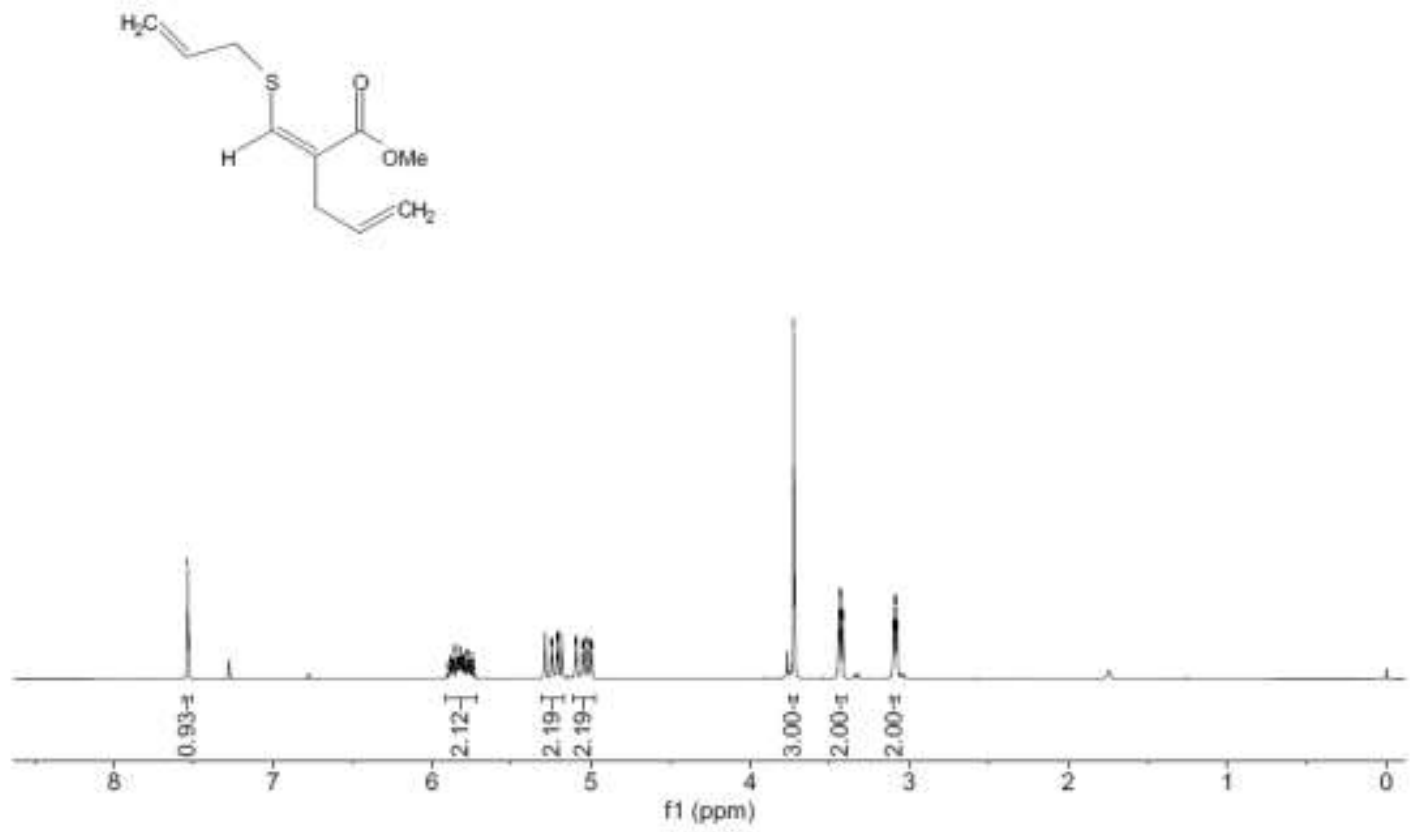

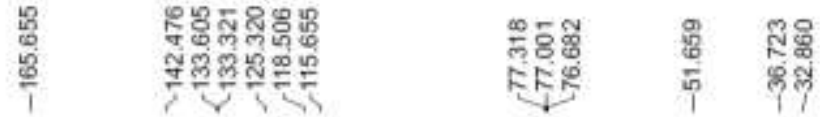

$\mathrm{H}_{2} \mathrm{C}$<smiles>CCS/C=C(/CC=O)C(=O)O</smiles>

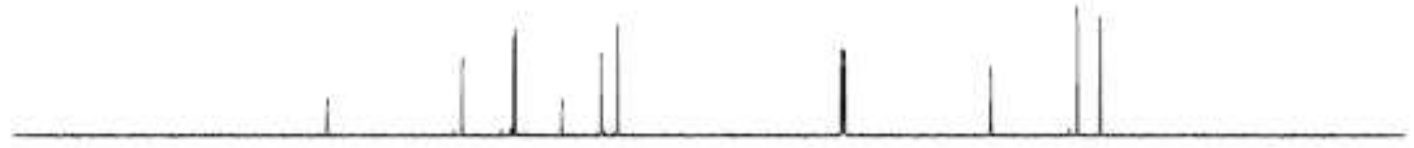

200

180

160

140

120 

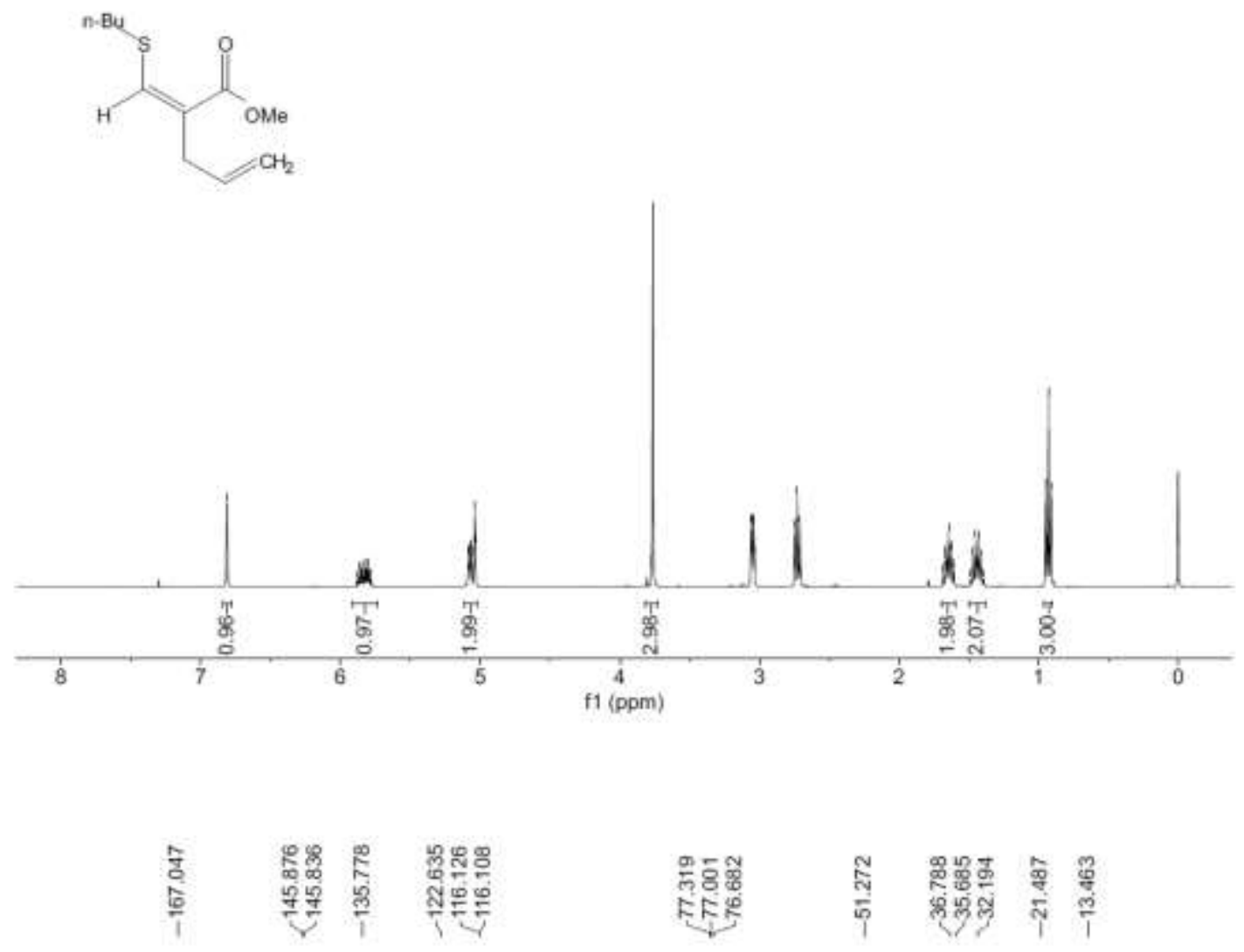<smiles>C=CC/C(=C\SCCCC)C(=O)OC</smiles>

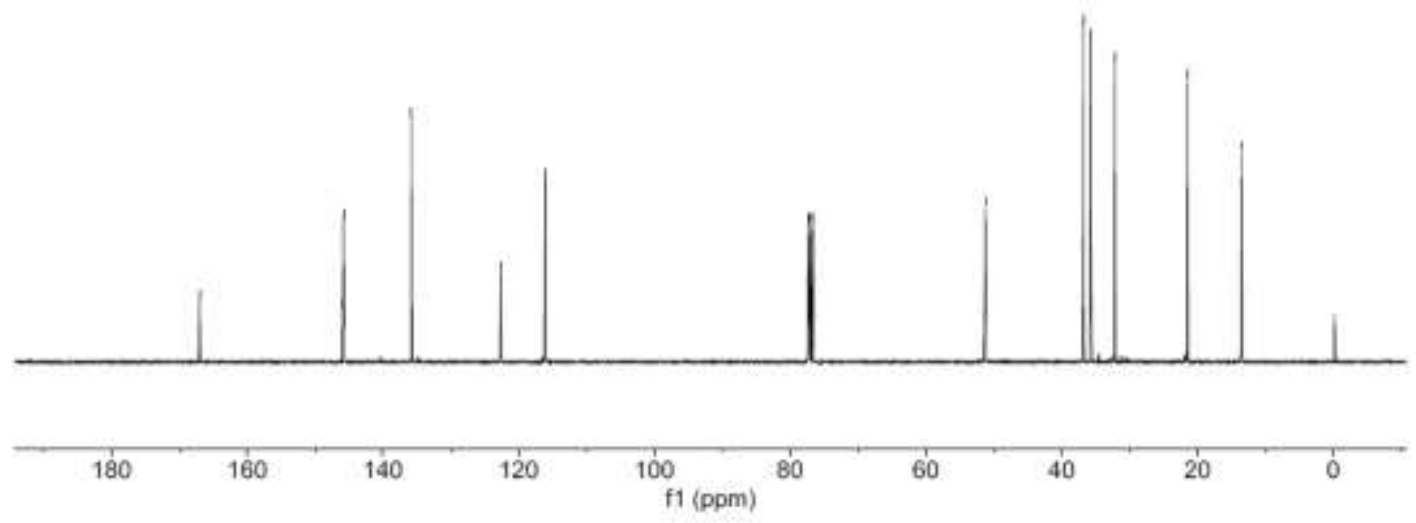

${ }^{1} \mathrm{H}$ NMR (400 MHz) and ${ }^{13} \mathrm{C}\left\{{ }^{1} \mathrm{H}\right\}$ NMR (100 MHz) spectra of $\mathbf{3 m}$ in $\mathrm{CDCl}_{3}$ 
<smiles>C=CC/C(=C/Sc1ccccc1)C(C)=O</smiles>

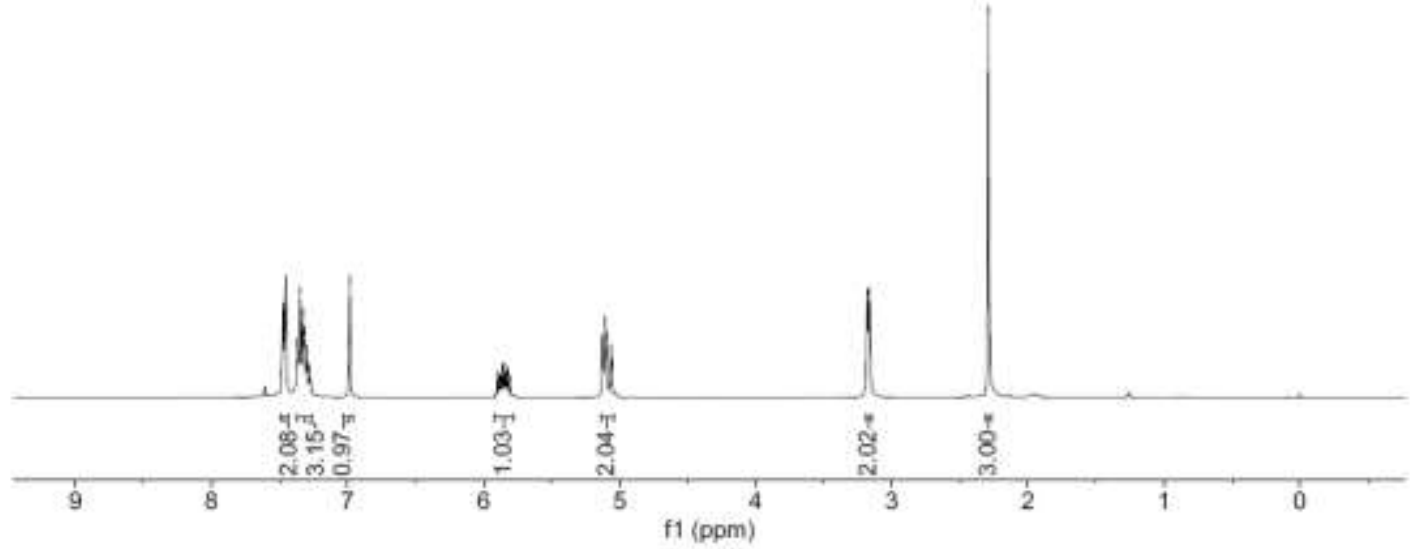<smiles>C=CC/C(=C\Sc1ccccc1)C(C)=O</smiles>

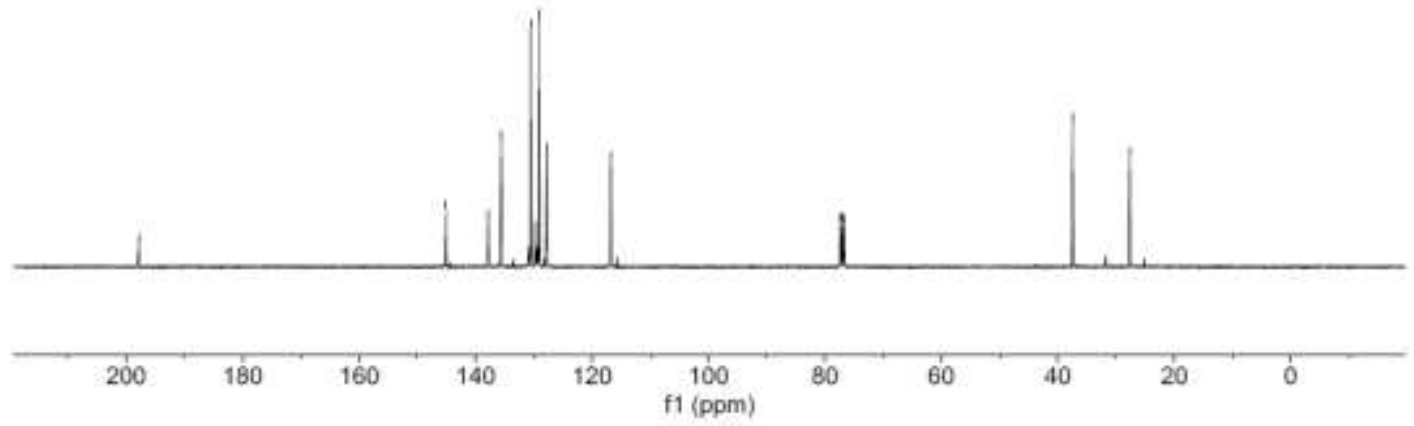

${ }^{1} \mathrm{H}$ NMR $(400 \mathrm{MHz})$ and ${ }^{13} \mathrm{C}\left\{{ }^{1} \mathrm{H}\right\}$ NMR $(100 \mathrm{MHz})$ spectra of $3 \mathbf{n}$ in $\mathrm{CDCl}_{3}$ 
<smiles>C=CC/C(=C\Sc1ccccc1)C(=O)O</smiles>

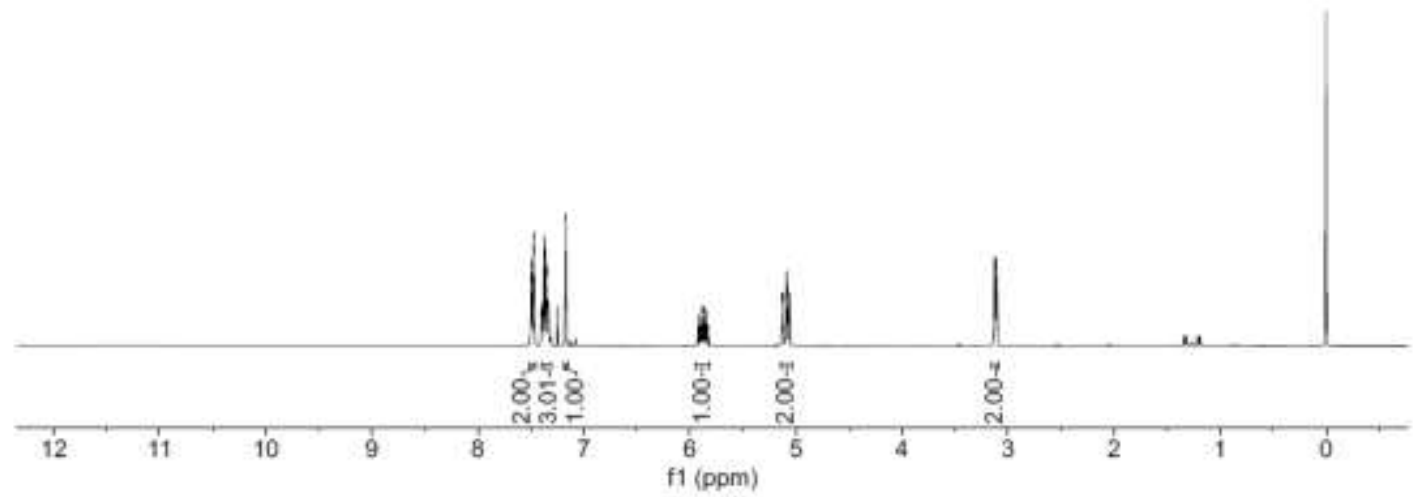<smiles>C=CC/C(=C/Sc1ccccc1)C(=O)O</smiles>

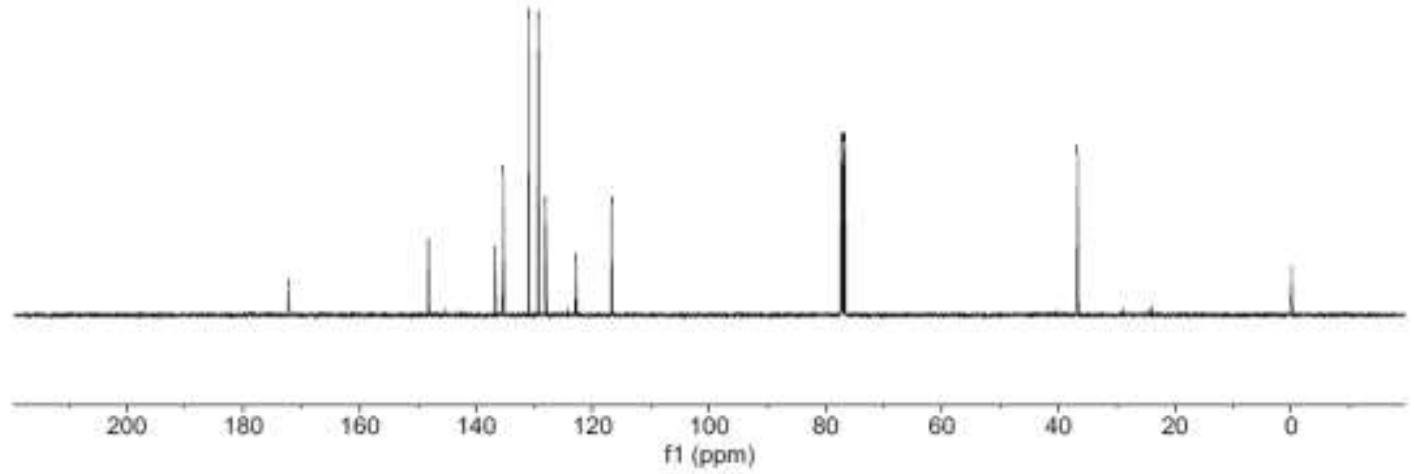

${ }^{1} \mathrm{H}$ NMR (400 MHz) and ${ }^{13} \mathrm{C}\left\{{ }^{1} \mathrm{H}\right\}$ NMR (100 MHz) spectra of 30 in $\mathrm{CDCl}_{3}$ 

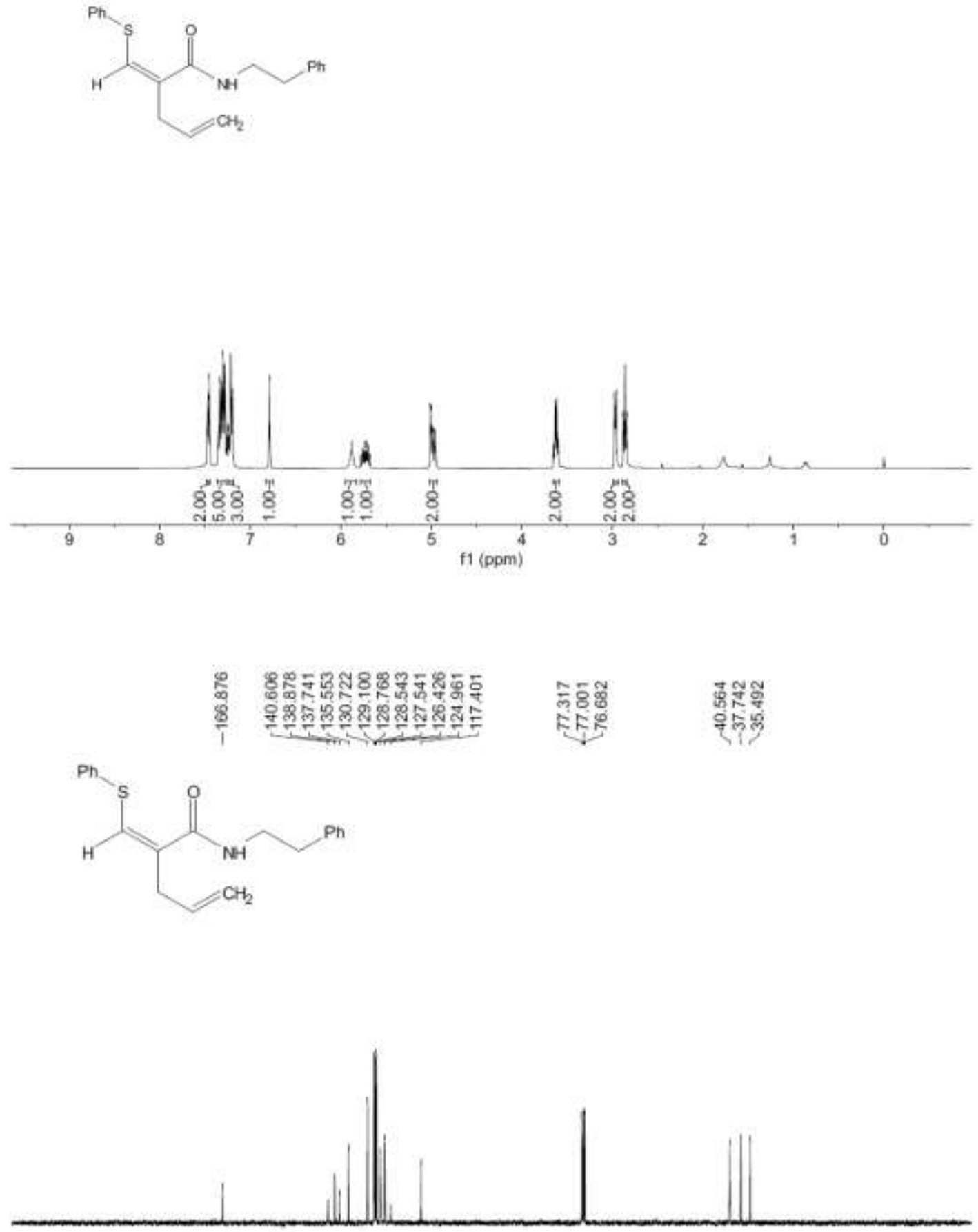

200

180

160

140

120

100

60

40

20 

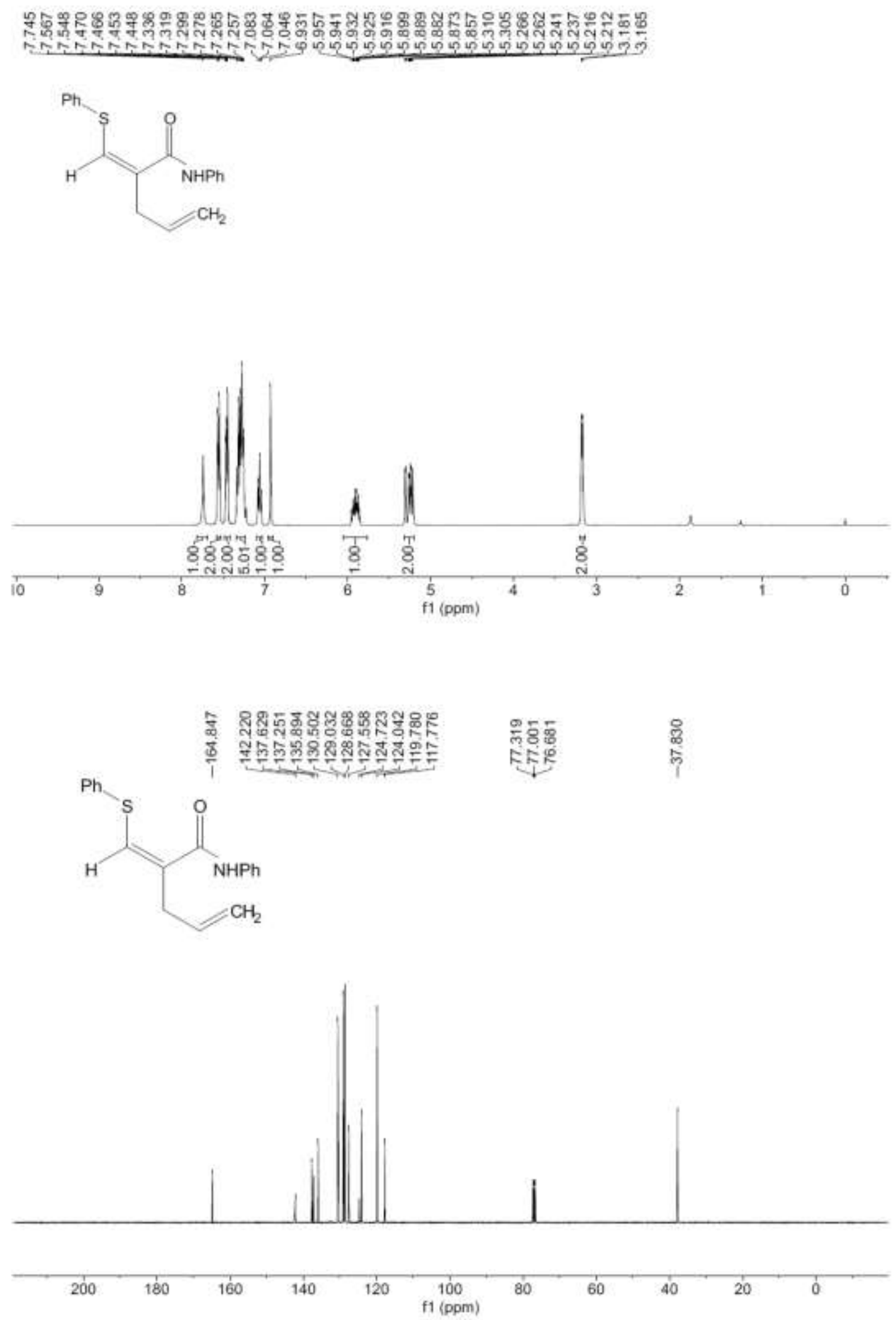

${ }^{1} \mathrm{H}$ NMR $(400 \mathrm{MHz})$ and ${ }^{13} \mathrm{C}\left\{{ }^{1} \mathrm{H}\right\}$ NMR $(100 \mathrm{MHz})$ spectra of $\mathbf{3 q}$ in $\mathrm{CDCl}_{3}$ 

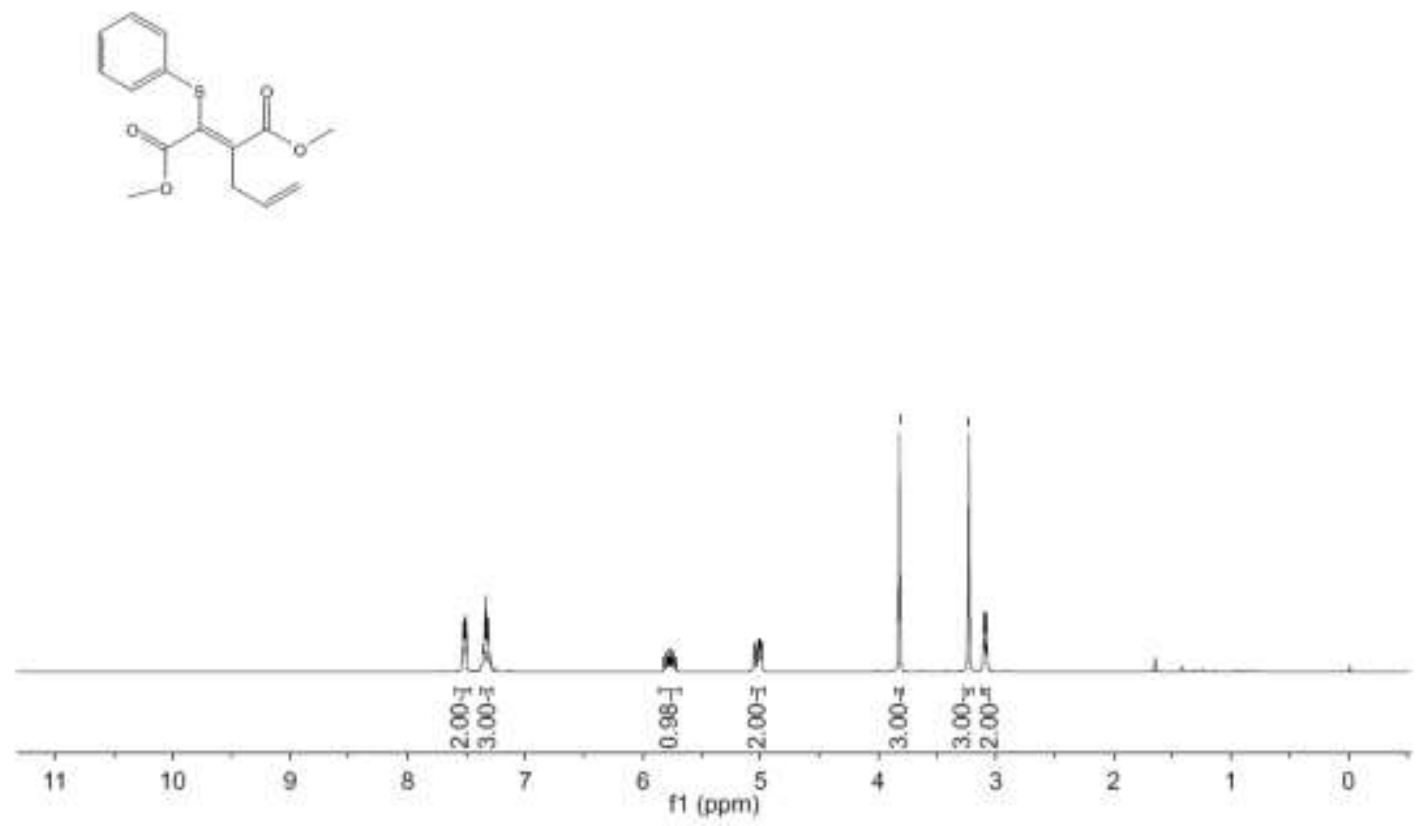

\begin{tabular}{|c|c|c|}
\hline 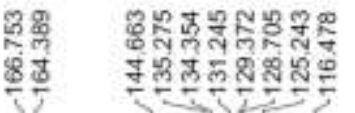 & 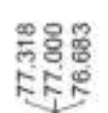 & 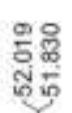 \\
\hline
\end{tabular}
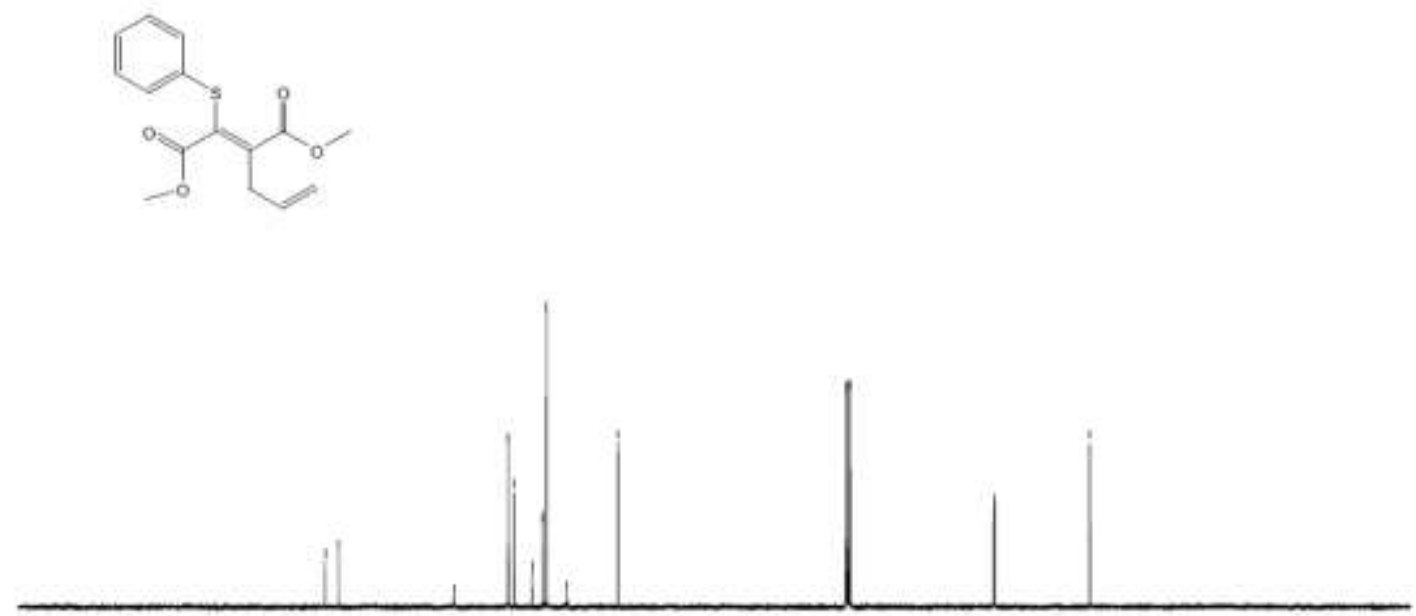

200

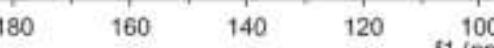

$11 \mathrm{ppm}$

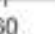

40

20 

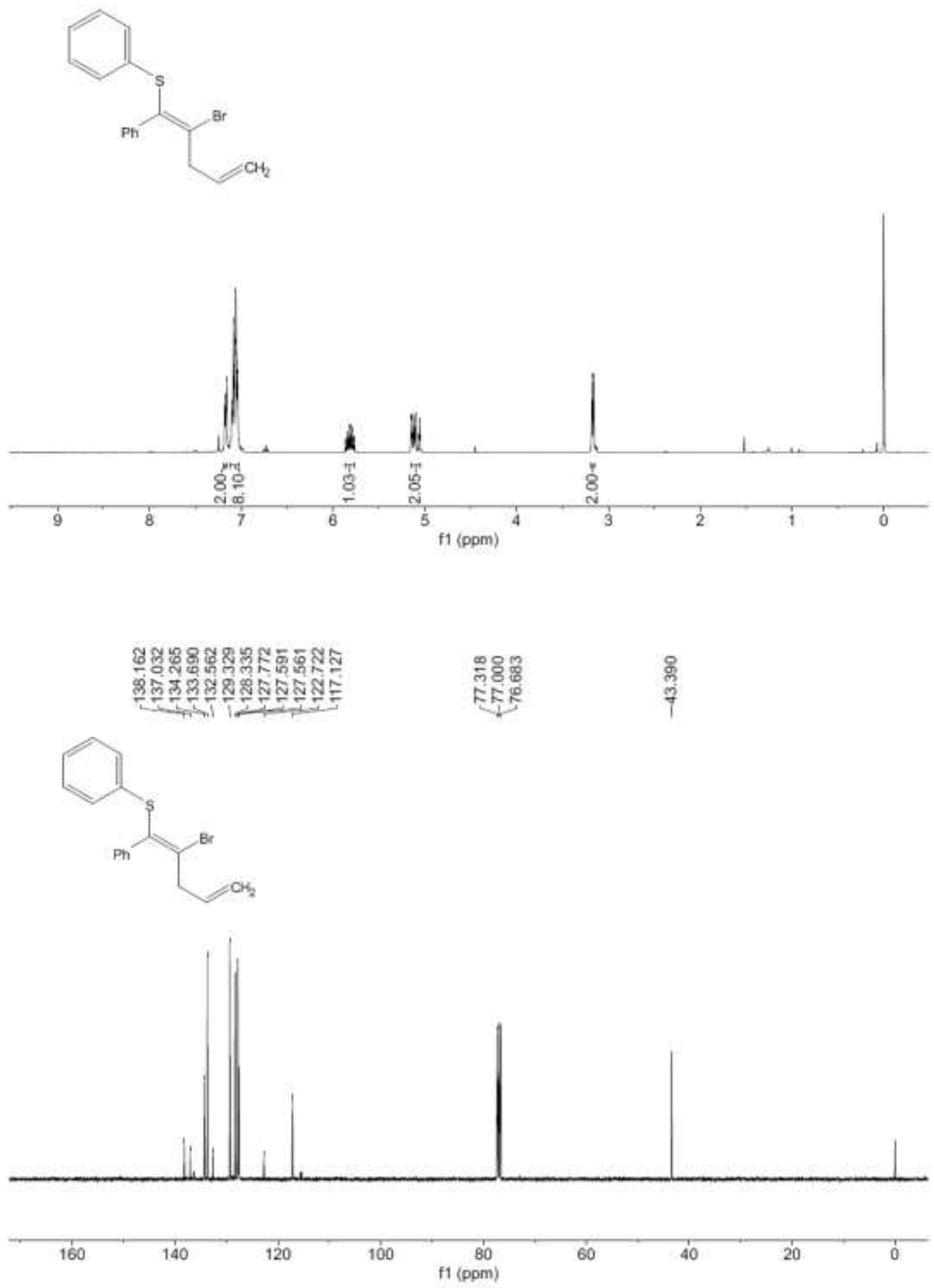

${ }^{1} \mathrm{H}$ NMR $(400 \mathrm{MHz})$ and ${ }^{13} \mathrm{C}\left\{{ }^{1} \mathrm{H}\right\}$ NMR $(100 \mathrm{MHz})$ spectra of $\mathbf{5 a}$ in $\mathrm{CDCl}_{3}$ 

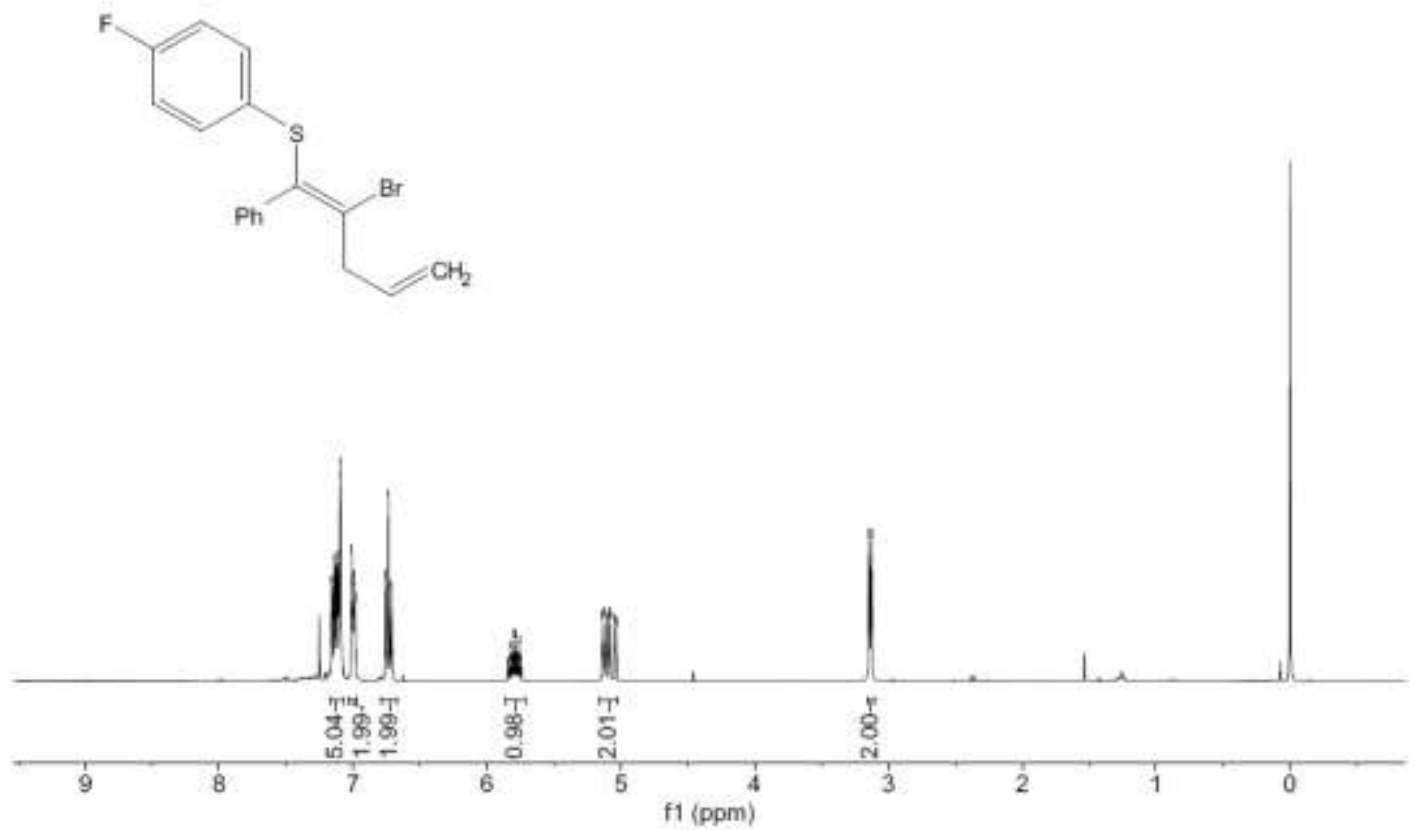

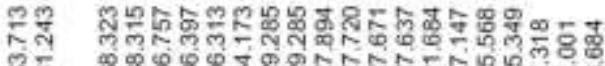

8ㄷ.

ำ
7
7
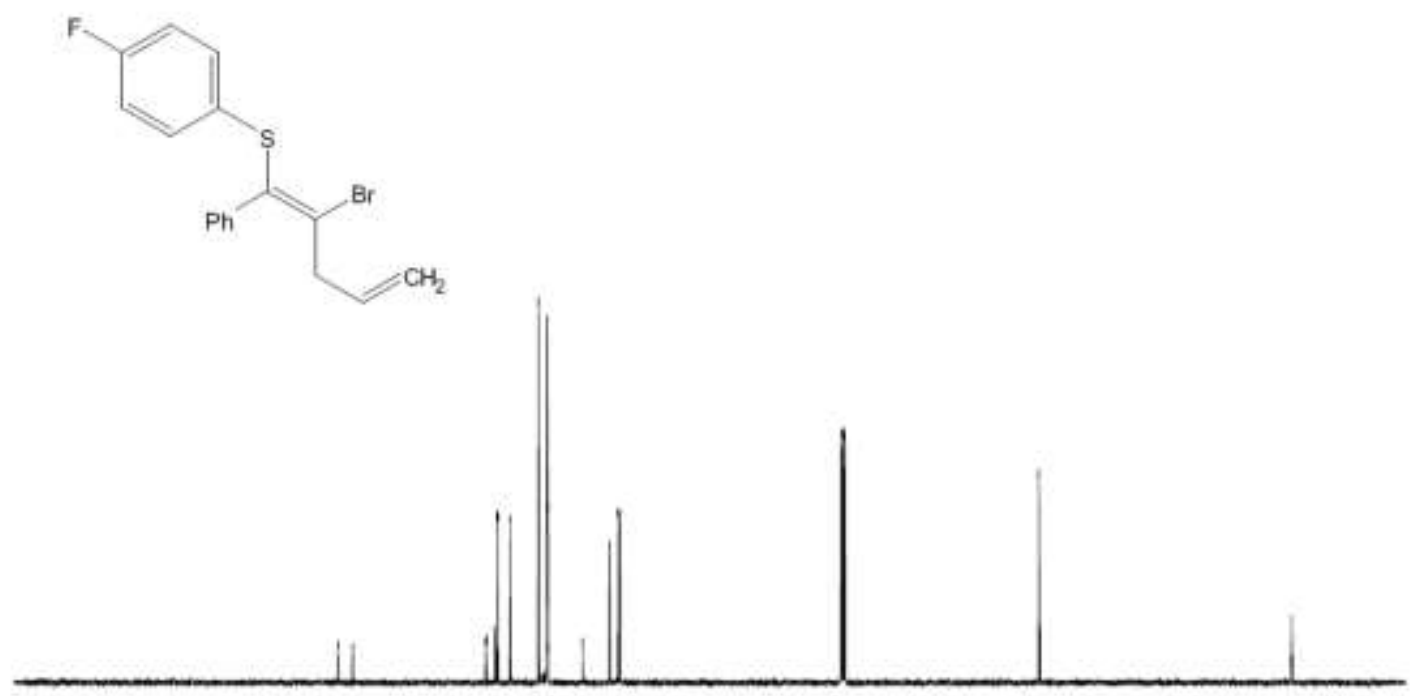

200

180

160

140

120

100

$80 \quad 60$

20

${ }^{1} \mathrm{H}$ NMR (400 MHz) and ${ }^{13} \mathrm{C}\left\{{ }^{1} \mathrm{H}\right\}$ NMR (100 MHz) spectra of $\mathbf{5 b}$ in $\mathrm{CDCl}_{3}$ 


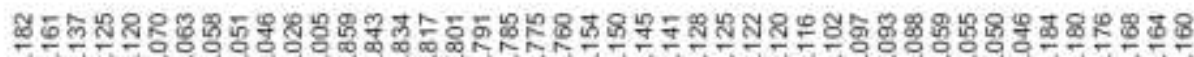

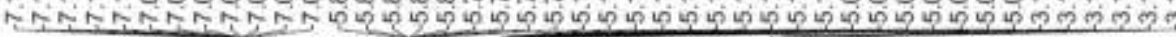
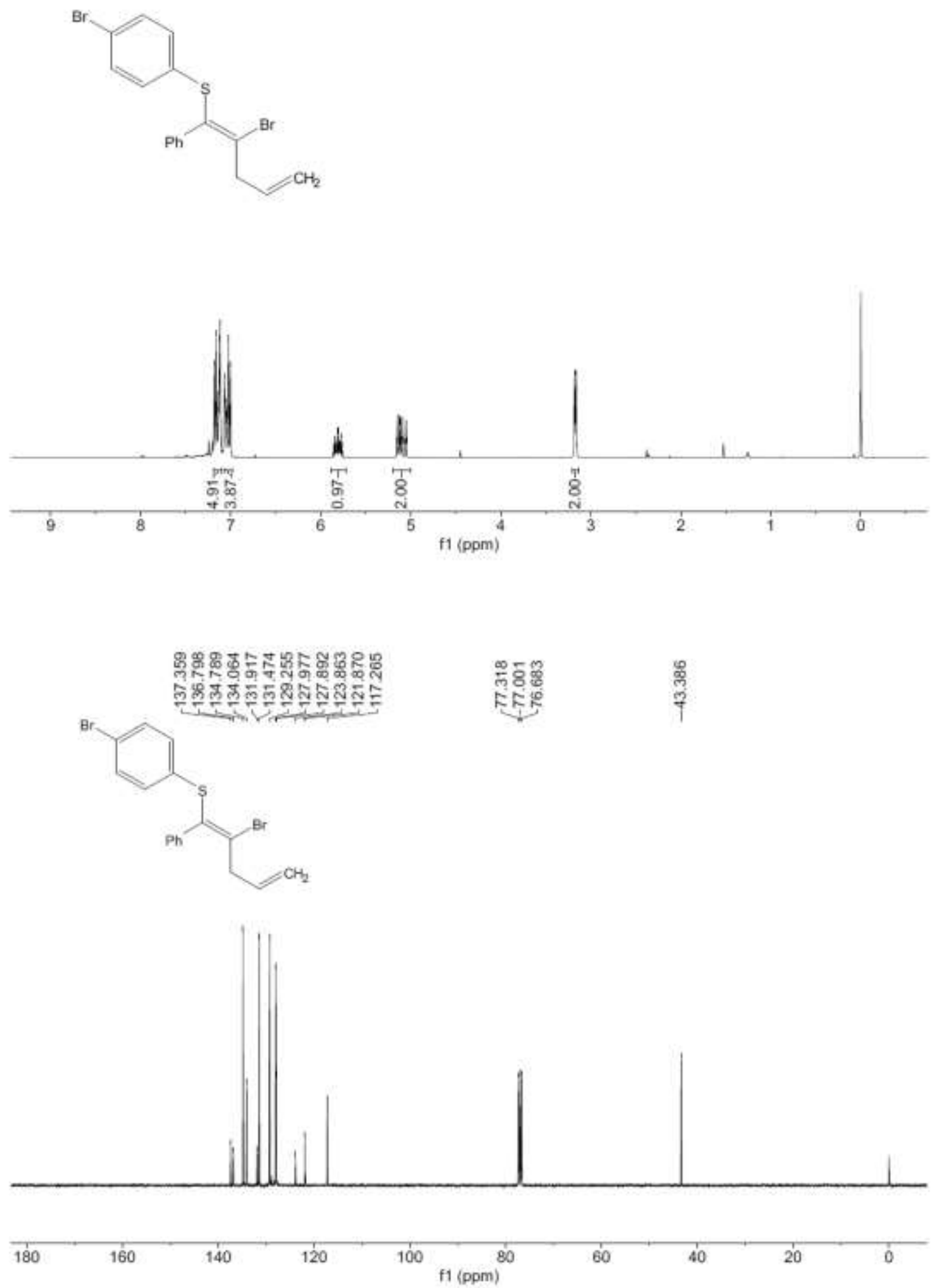

${ }^{1} \mathrm{H}$ NMR $(400 \mathrm{MHz})$ and ${ }^{13} \mathrm{C}\left\{{ }^{1} \mathrm{H}\right\}$ NMR $(100 \mathrm{MHz})$ spectra of $\mathbf{5 c}$ in $\mathrm{CDCl}_{3}$ 


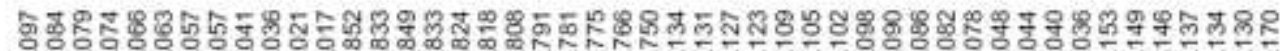

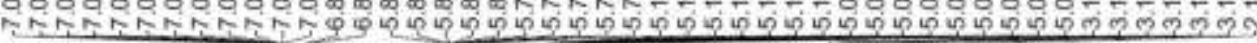
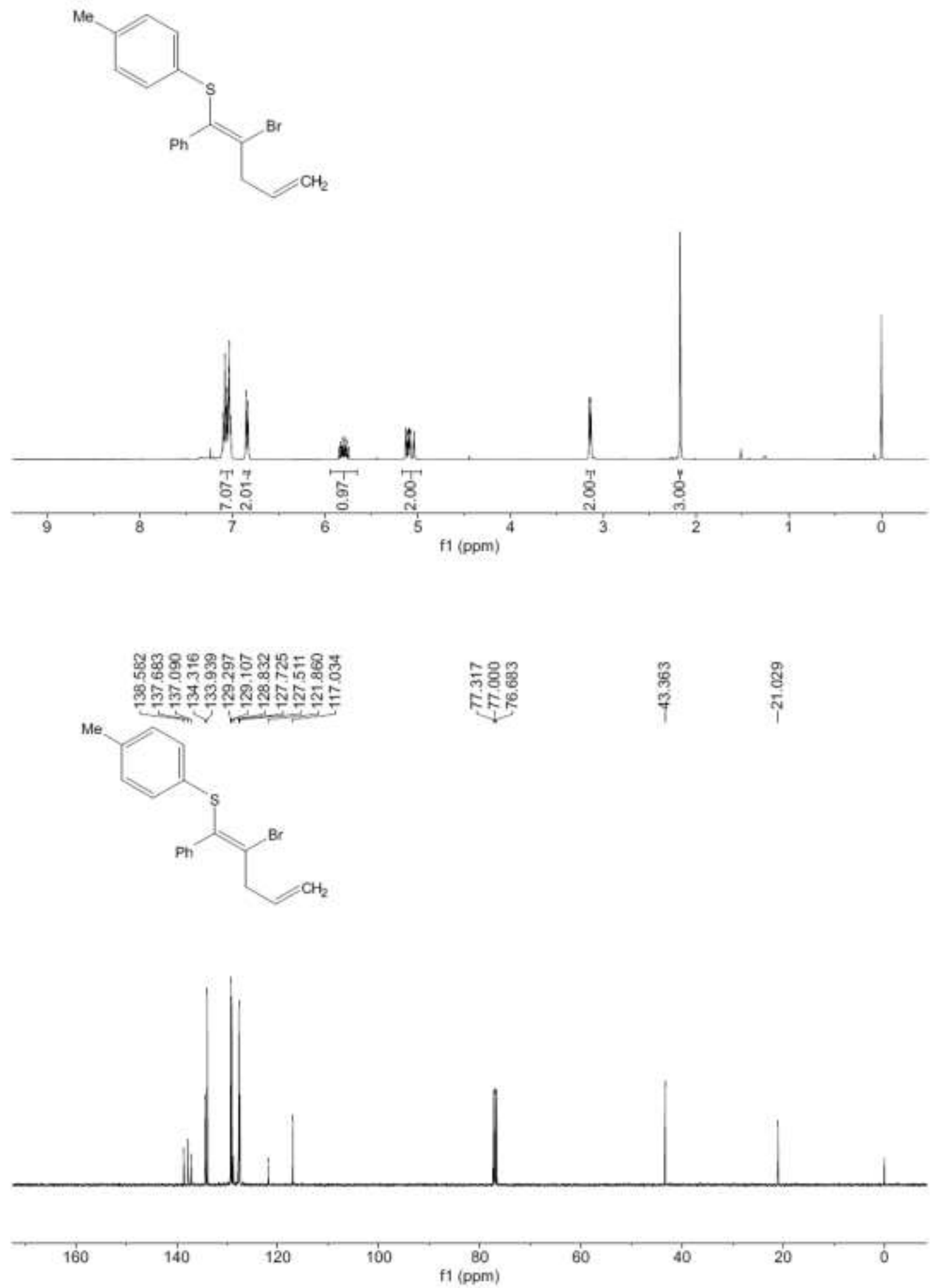

${ }^{1} \mathrm{H}$ NMR (400 MHz) and ${ }^{13} \mathrm{C}\left\{{ }^{1} \mathrm{H}\right\}$ NMR (100 MHz) spectra of $\mathbf{5 d}$ in $\mathrm{CDCl}_{3}$ 

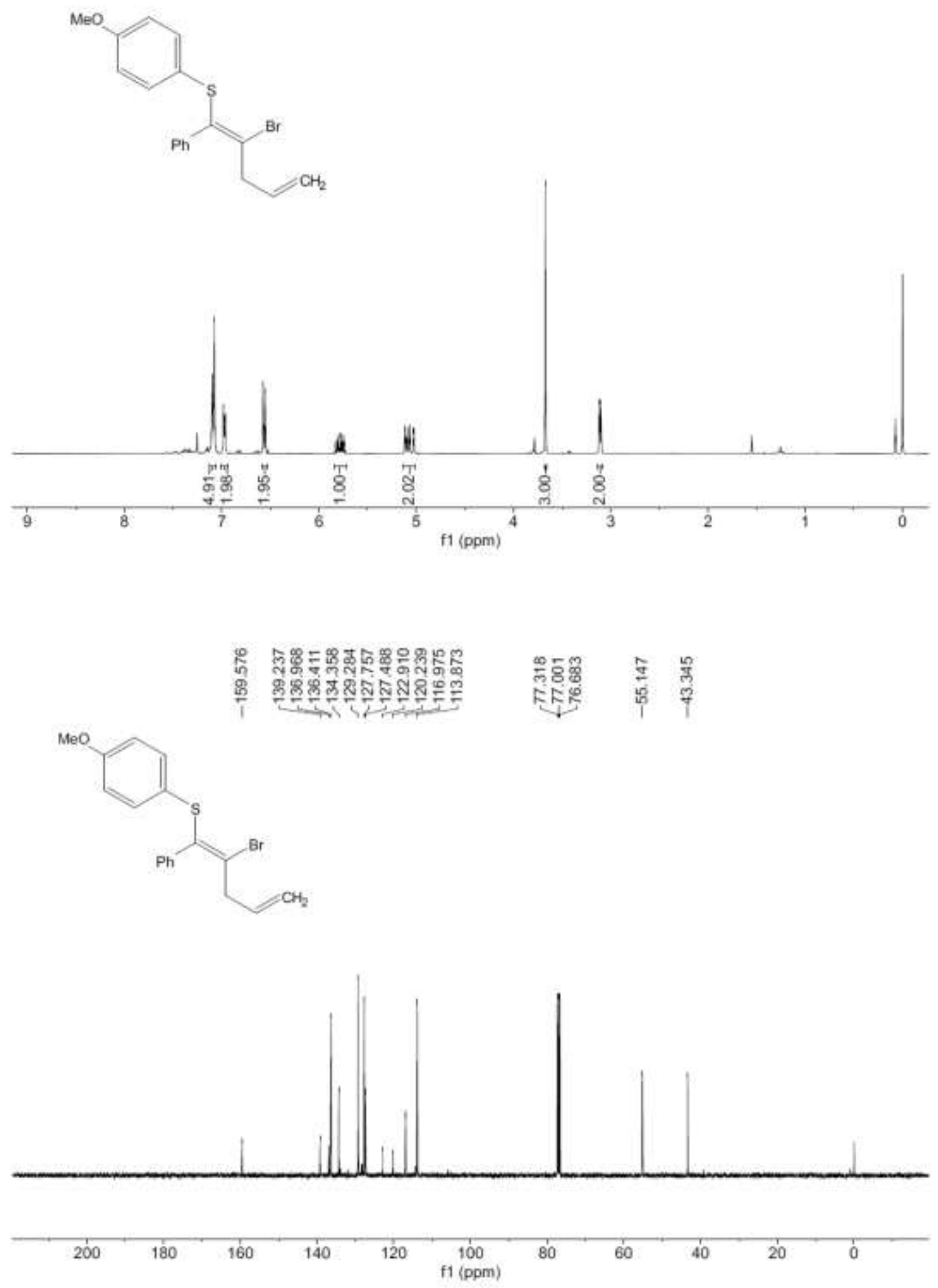

${ }^{1} \mathrm{H}$ NMR (400 MHz) and ${ }^{13} \mathrm{C}\left\{{ }^{1} \mathrm{H}\right\}$ NMR (100 MHz) spectra of $\mathbf{5 e}$ in $\mathrm{CDCl}_{3}$ 
<smiles>C=CC/C(Br)=C(/Sc1ccccc1C)c1ccccc1</smiles>

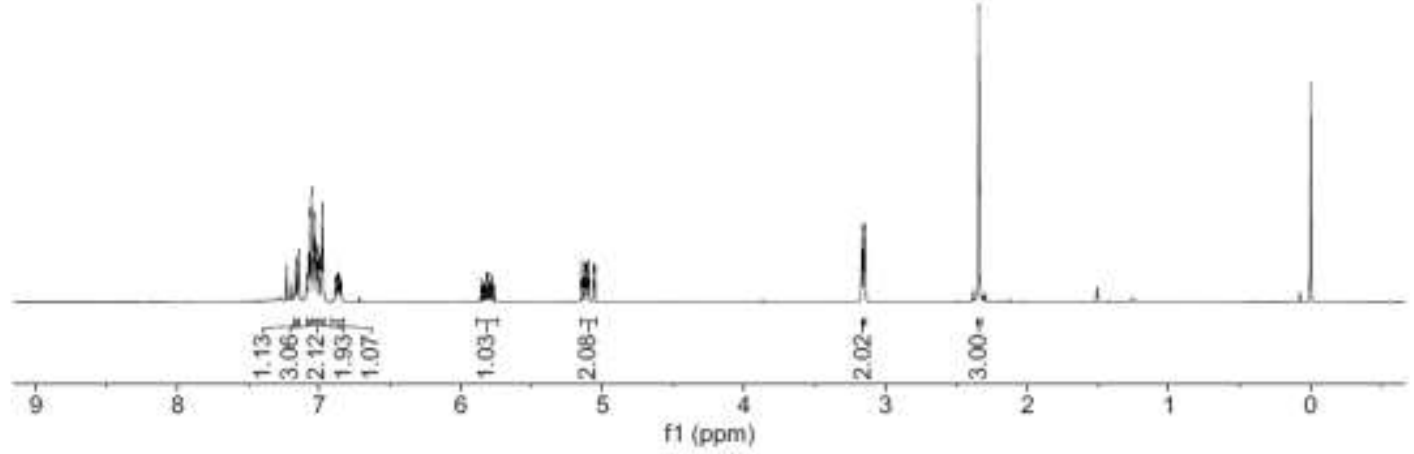

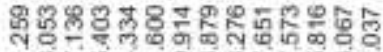

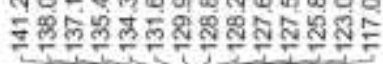

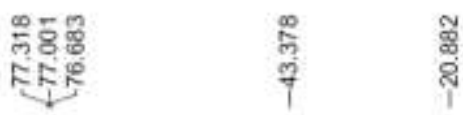<smiles>C=CC/C(Br)=C(\Sc1ccccc1C)c1ccccc1</smiles>

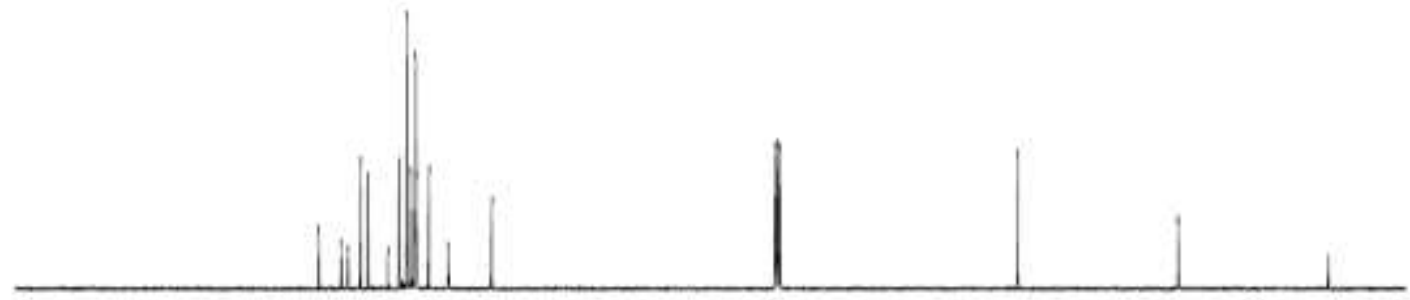

${ }^{1} \mathrm{H}$ NMR (400 MHz) and ${ }^{13} \mathrm{C}\left\{{ }^{1} \mathrm{H}\right\}$ NMR (100 MHz) spectra of $\mathbf{5 f}$ in $\mathrm{CDCl}_{3}$ 

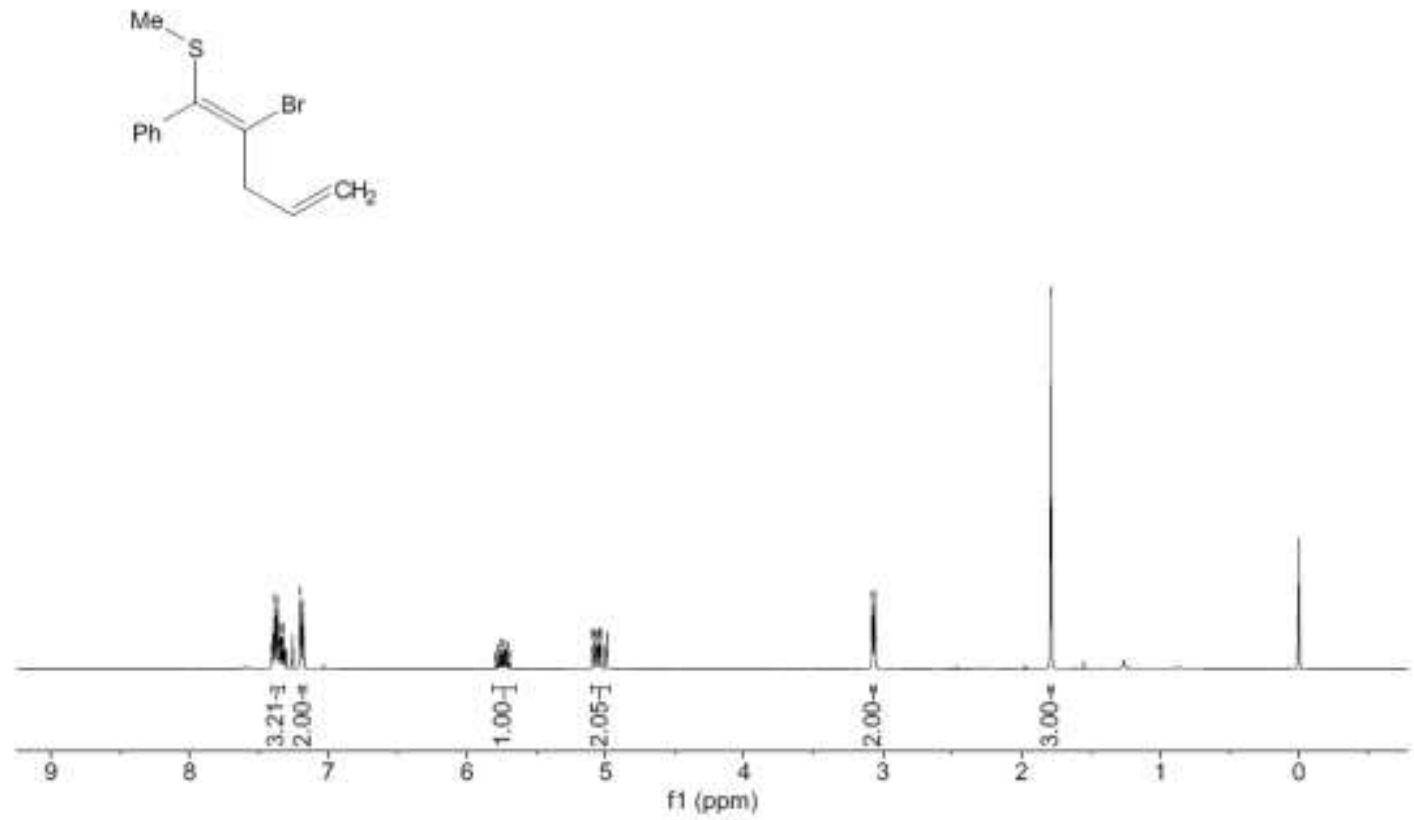

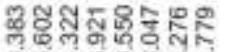

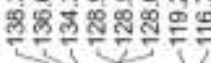

बูले

RF!

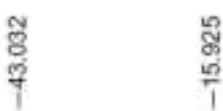<smiles>C=CC/C(Br)=C(\SC)c1ccccc1</smiles>

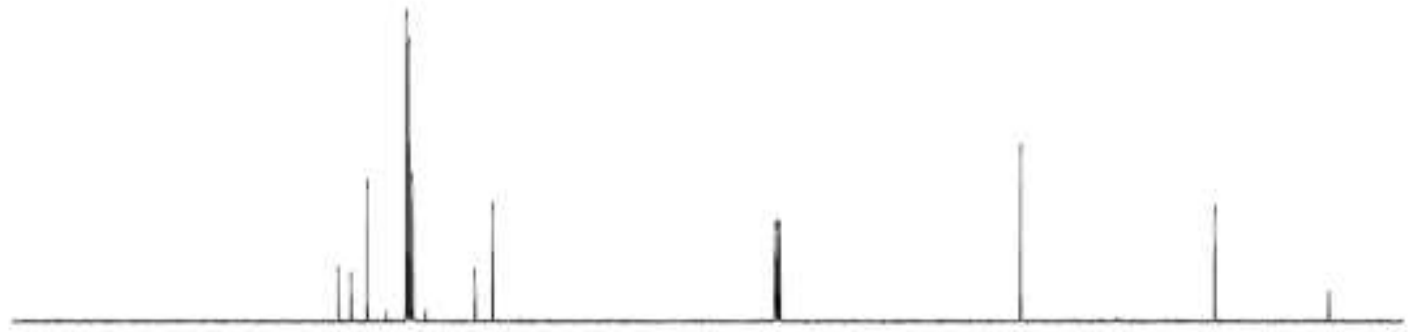

${ }^{1} \mathrm{H}$ NMR (400 MHz) and ${ }^{13} \mathrm{C}\left\{{ }^{1} \mathrm{H}\right\}$ NMR (100 MHz) spectra of $\mathbf{5 g}$ in $\mathrm{CDCl}_{3}$ 
<smiles>C=CC/C(Br)=C(/Sc1ccccc1)c1ccc(F)cc1</smiles>
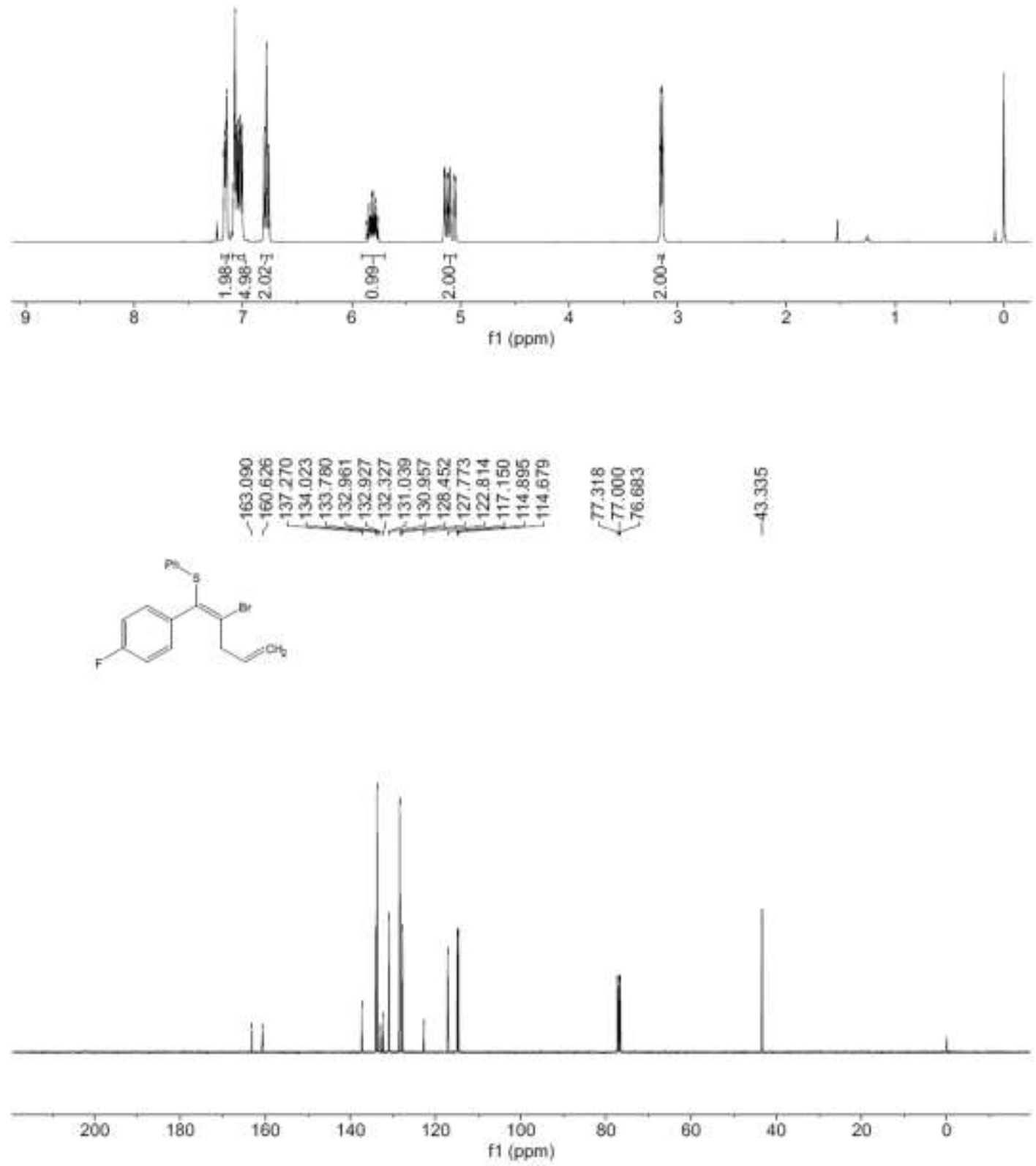

${ }^{1} \mathrm{H}$ NMR $(400 \mathrm{MHz})$ and ${ }^{13} \mathrm{C}\left\{{ }^{1} \mathrm{H}\right\} \mathrm{NMR}(100 \mathrm{MHz})$ spectra of $\mathbf{5 h}$ in $\mathrm{CDCl}_{3}$ 
<smiles>C=CCC(Br)=C(Sc1ccccc1)c1cccc(C)c1</smiles>

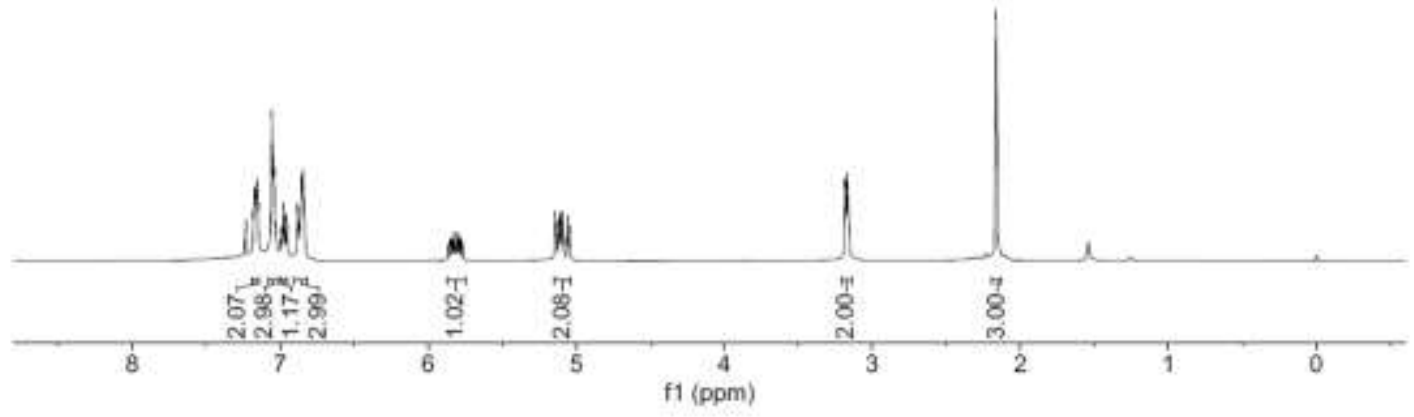

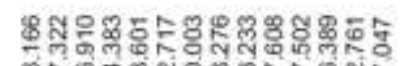

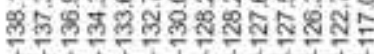
요용 FEF 桨<smiles>C=CCC(Br)=C(Sc1ccccc1)c1cccc(C)c1</smiles>

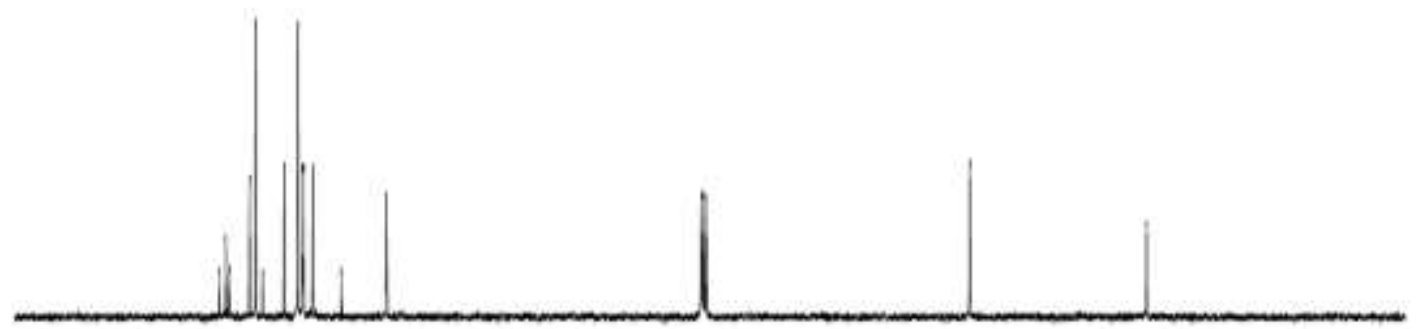

${ }^{1} \mathrm{H}$ NMR (400 MHz) and ${ }^{13} \mathrm{C}\left\{{ }^{1} \mathrm{H}\right\}$ NMR (100 MHz) spectra of $\mathbf{5 i}$ in $\mathrm{CDCl}_{3}$ 

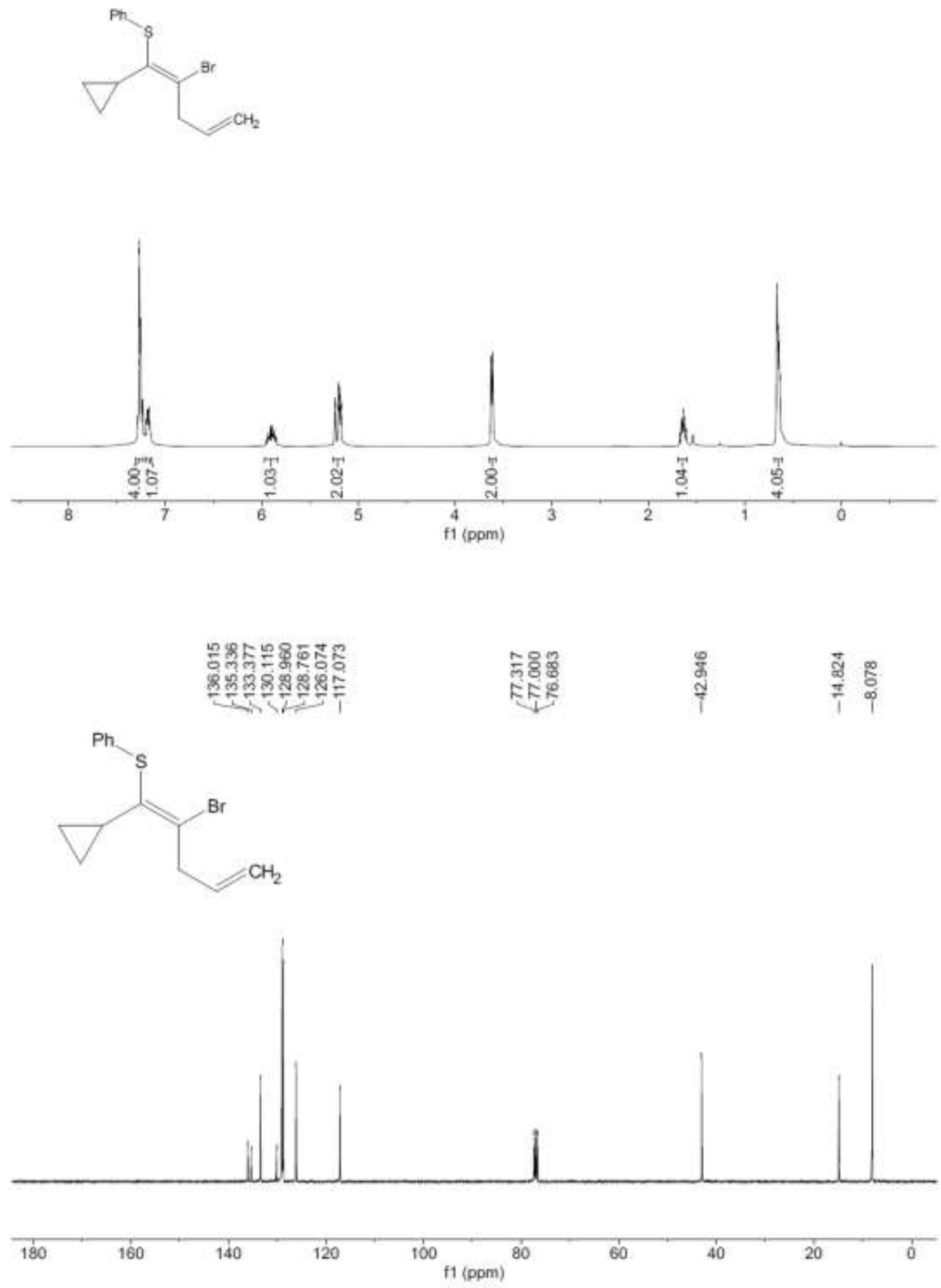

${ }^{1} \mathrm{H}$ NMR (400 MHz) and ${ }^{13} \mathrm{C}\left\{{ }^{1} \mathrm{H}\right\} \mathrm{NMR}(100 \mathrm{MHz})$ spectra of $\mathbf{5 j}$ in $\mathrm{CDCl}_{3}$ 


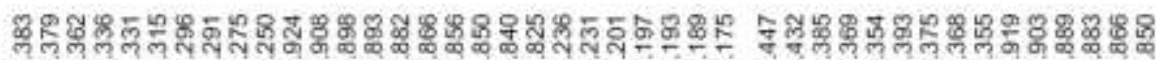

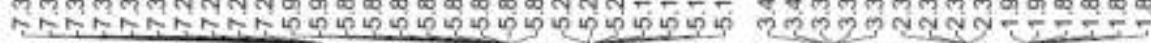
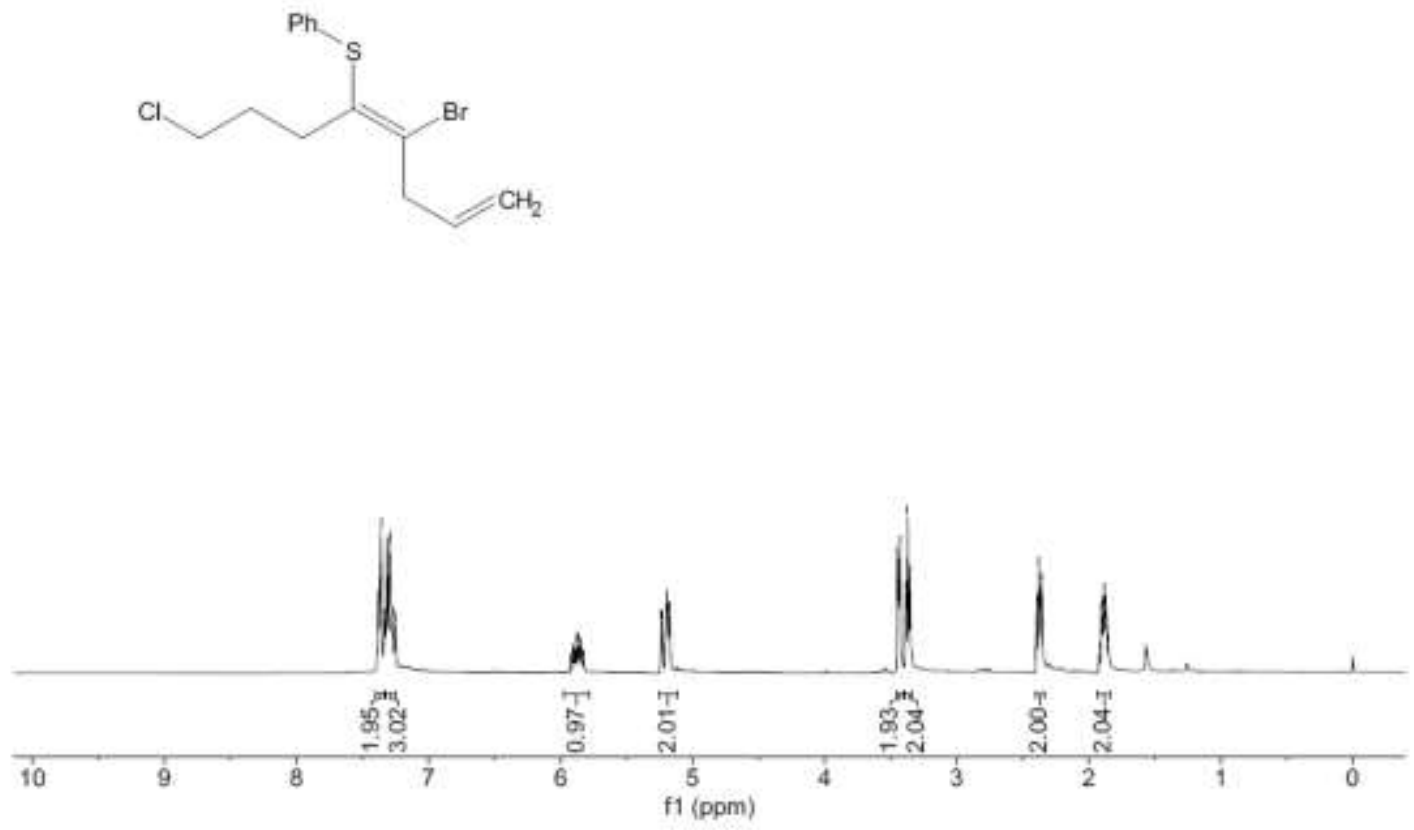

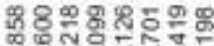

Bำ
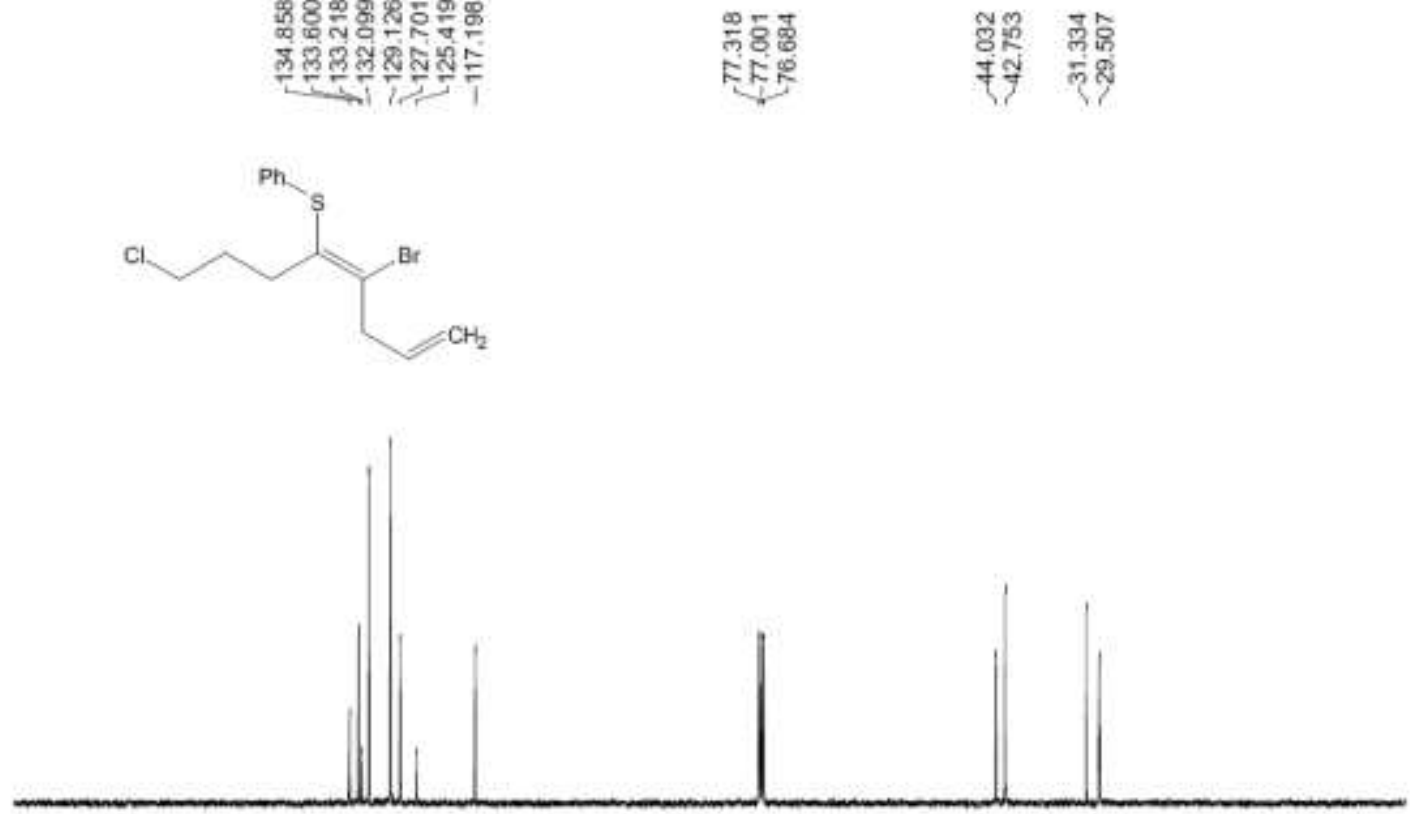

180

160

140

120

100

60

40

20

f1 (ppm)

${ }^{1} \mathrm{H}$ NMR (400 MHz) and ${ }^{13} \mathrm{C}\left\{{ }^{1} \mathrm{H}\right\}$ NMR (100 MHz) spectra of $\mathbf{5} \mathbf{k}$ in $\mathrm{CDCl}_{3}$ 

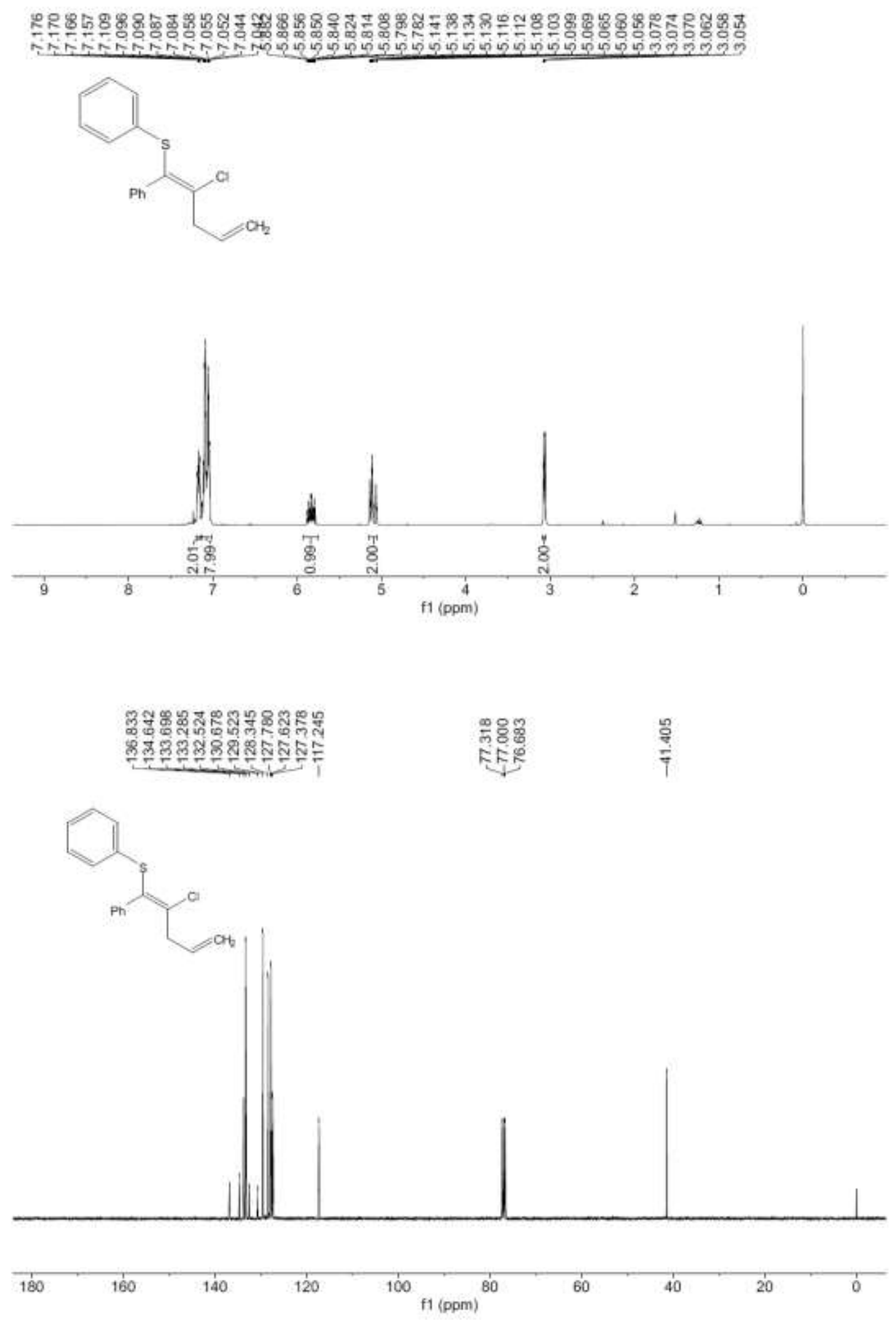

${ }^{1} \mathrm{H}$ NMR (400 MHz) and ${ }^{13} \mathrm{C}\left\{{ }^{1} \mathrm{H}\right\}$ NMR (100 MHz) spectra of $\mathbf{5 l}$ in $\mathrm{CDCl}_{3}$ 

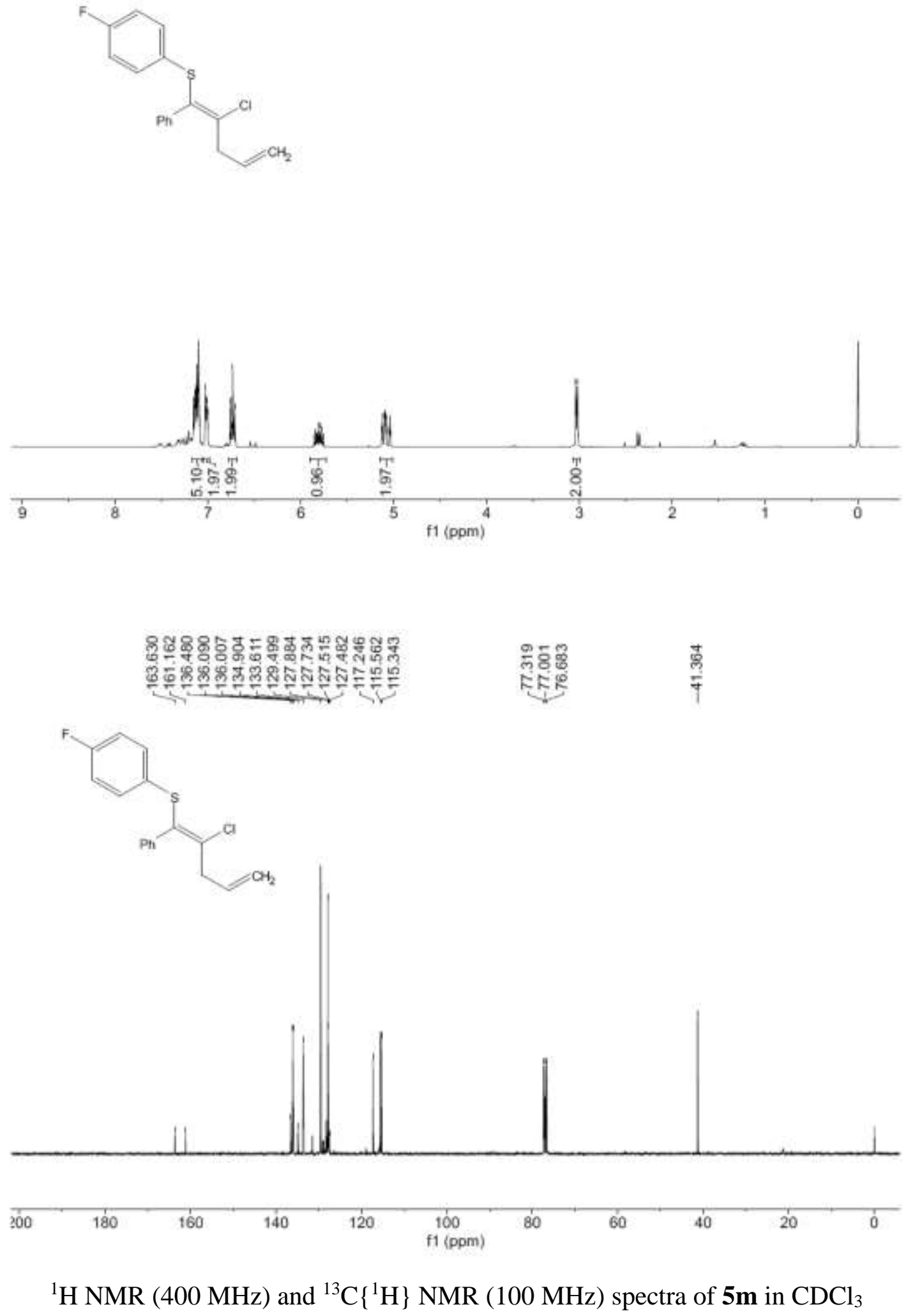
<smiles>CCCC(Cl)=C(Sc1ccc(Br)cc1)c1ccccc1</smiles>
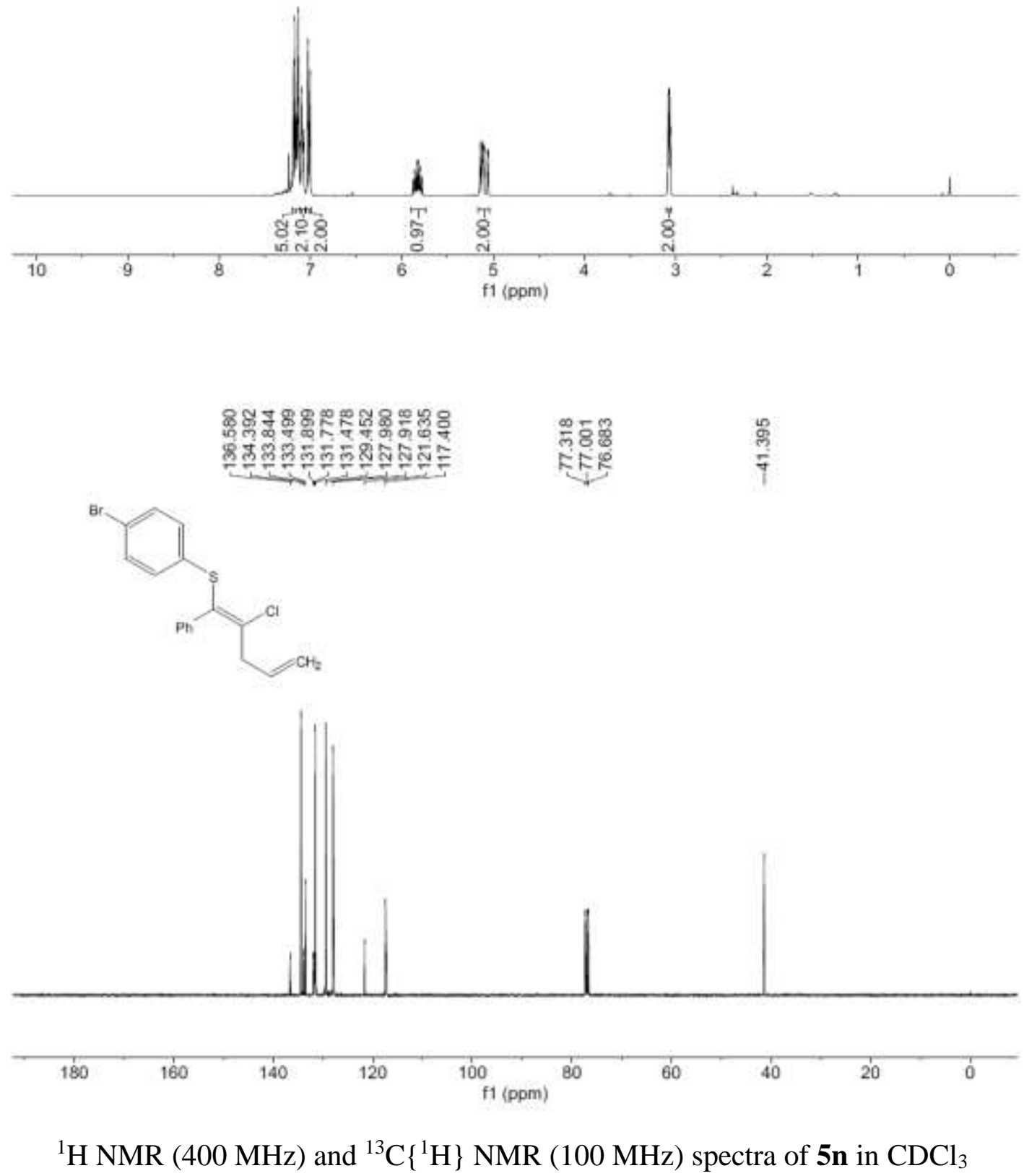

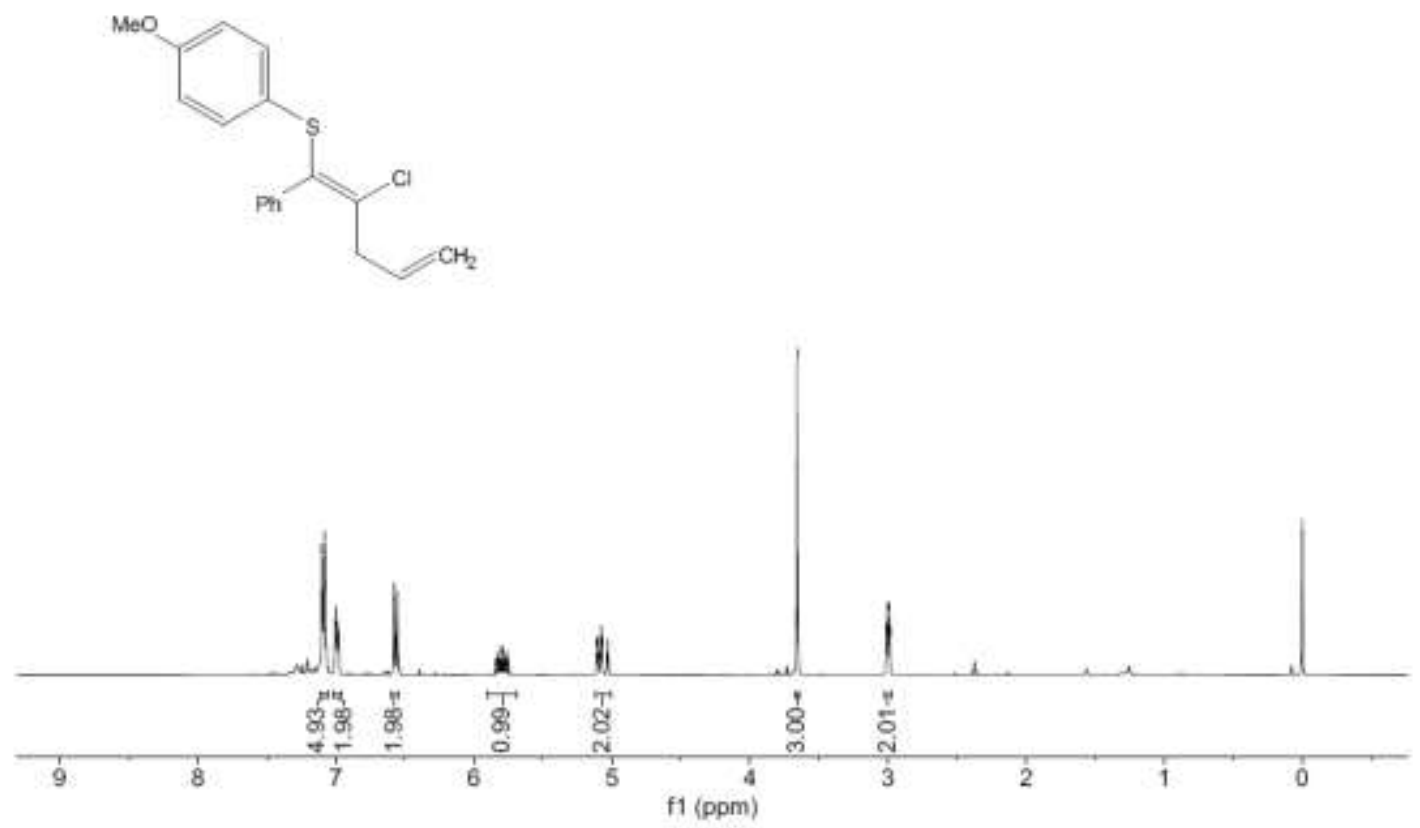

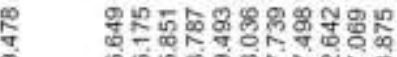

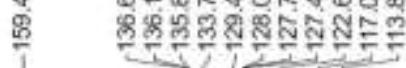

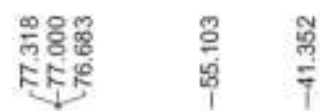<smiles>COc1ccc(S/C=C(\Cl)CCO)cc1</smiles>

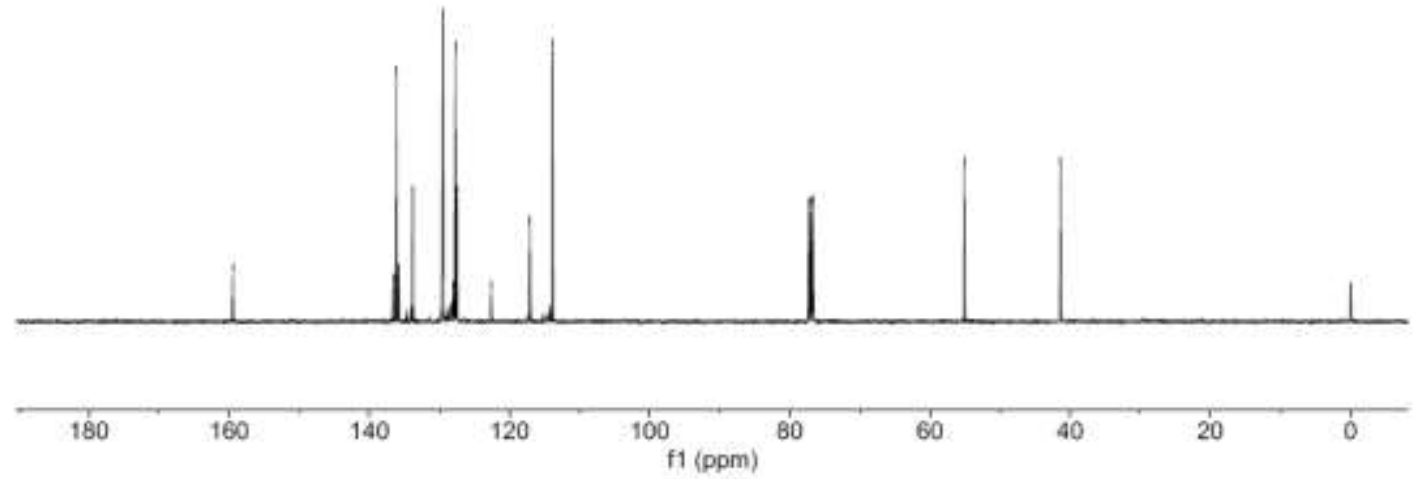

${ }^{1} \mathrm{H}$ NMR (400 MHz) and ${ }^{13} \mathrm{C}\left\{{ }^{1} \mathrm{H}\right\}$ NMR (100 MHz) spectra of 5o in $\mathrm{CDCl}_{3}$ 

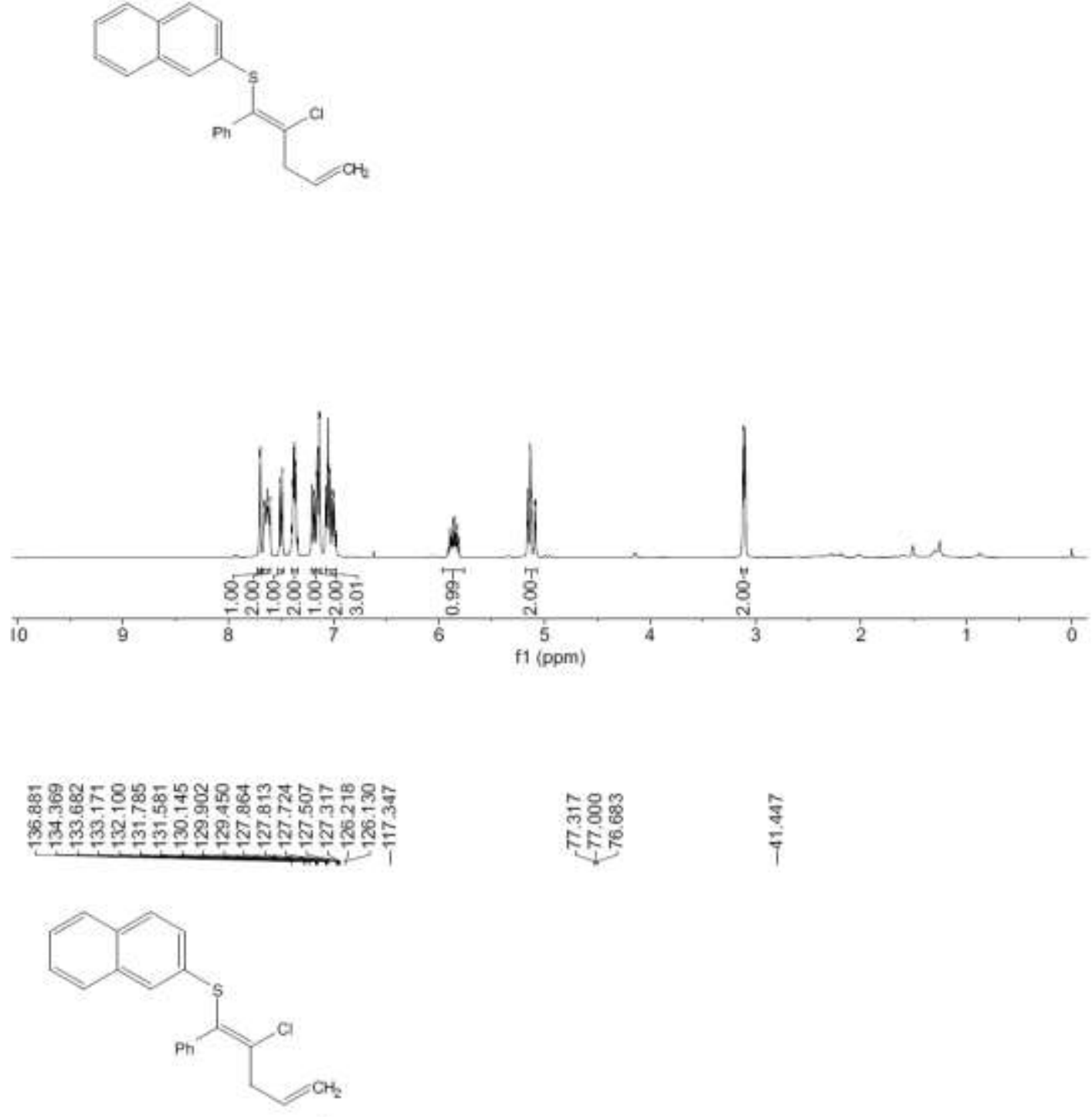

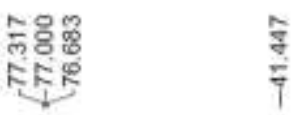

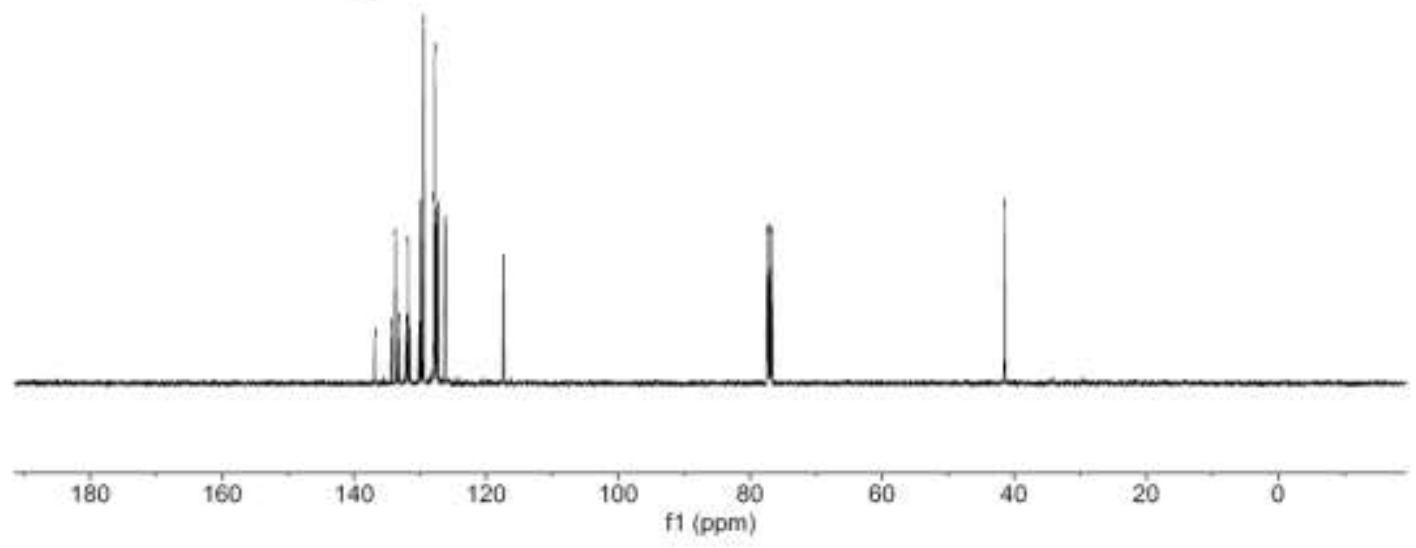

${ }^{1} \mathrm{H}$ NMR $(400 \mathrm{MHz})$ and ${ }^{13} \mathrm{C}\left\{{ }^{1} \mathrm{H}\right\} \mathrm{NMR}(100 \mathrm{MHz})$ spectra of $\mathbf{5 p}$ in $\mathrm{CDCl}_{3}$ 

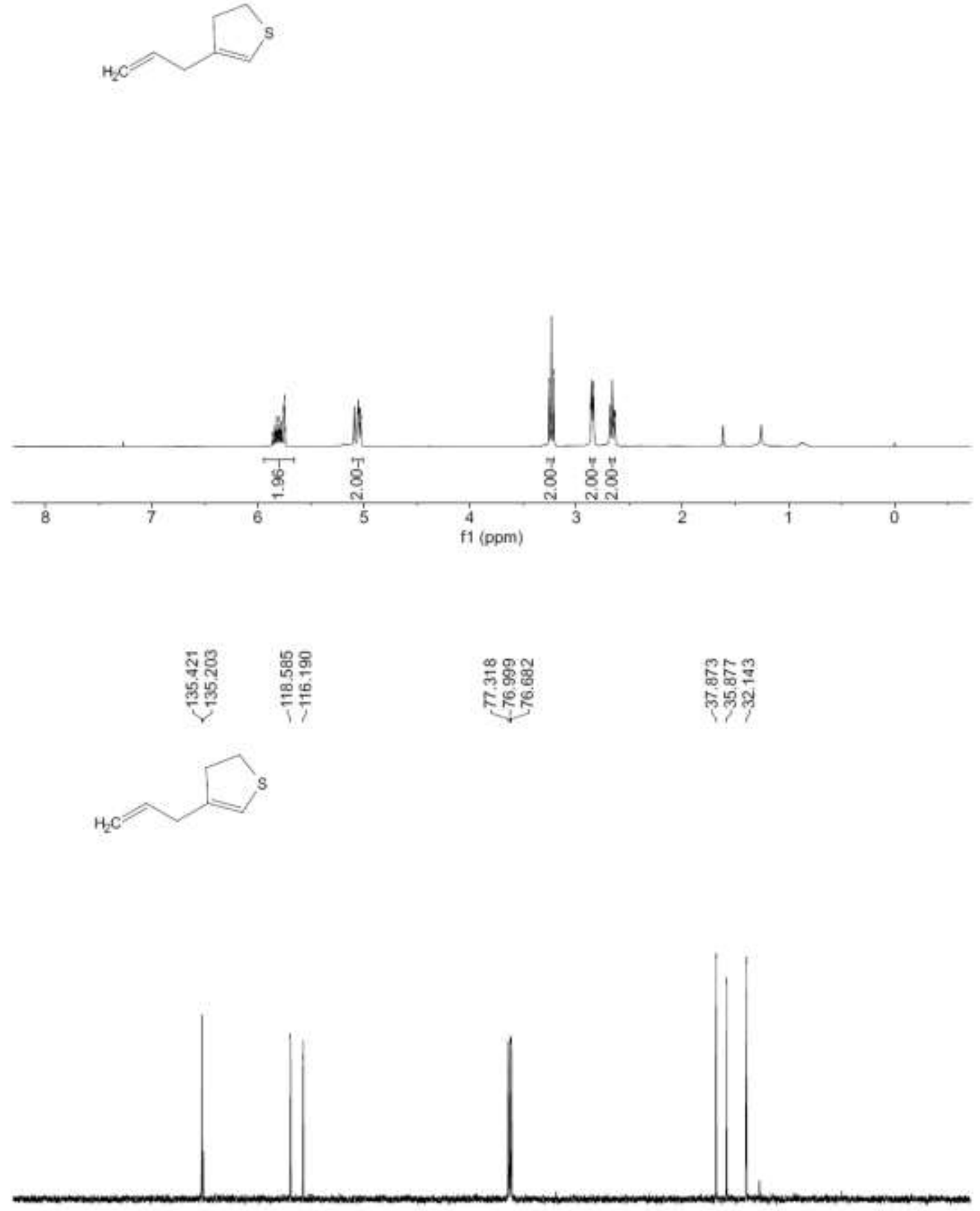

160

140

120

100

80
$\mathrm{f} 1(\mathrm{ppm})$

60

40

20

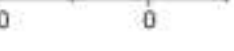

${ }^{1} \mathrm{H}$ NMR (400 MHz) and ${ }^{13} \mathrm{C}\left\{{ }^{1} \mathrm{H}\right\}$ NMR (100 MHz) spectra of 7a in $\mathrm{CDCl}_{3}$ 

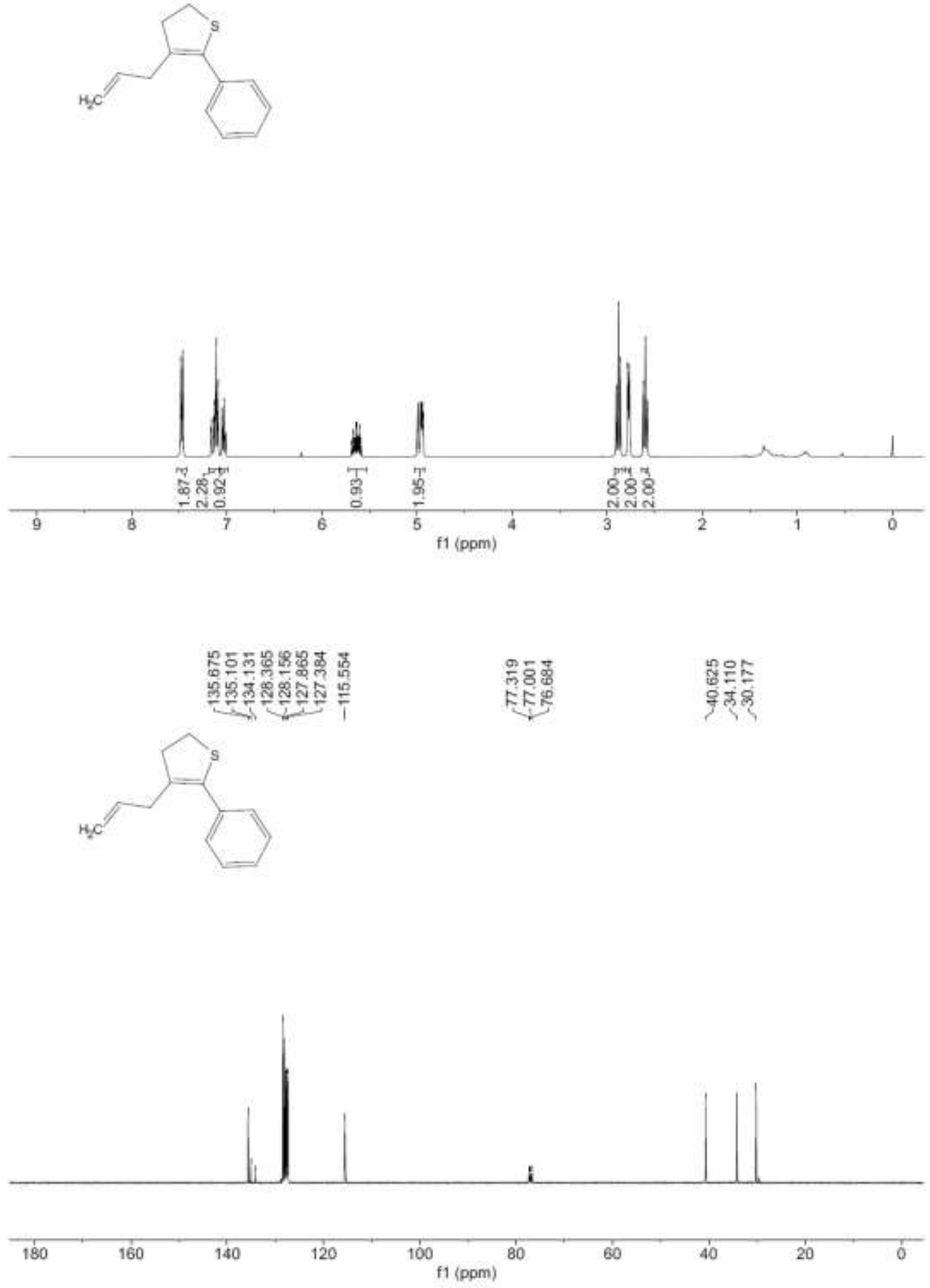

${ }^{1} \mathrm{H}$ NMR (400 MHz) and ${ }^{13} \mathrm{C}\left\{{ }^{1} \mathrm{H}\right\}$ NMR (100 MHz) spectra of $7 \mathbf{b}$ in $\mathrm{CDCl}_{3}$ 

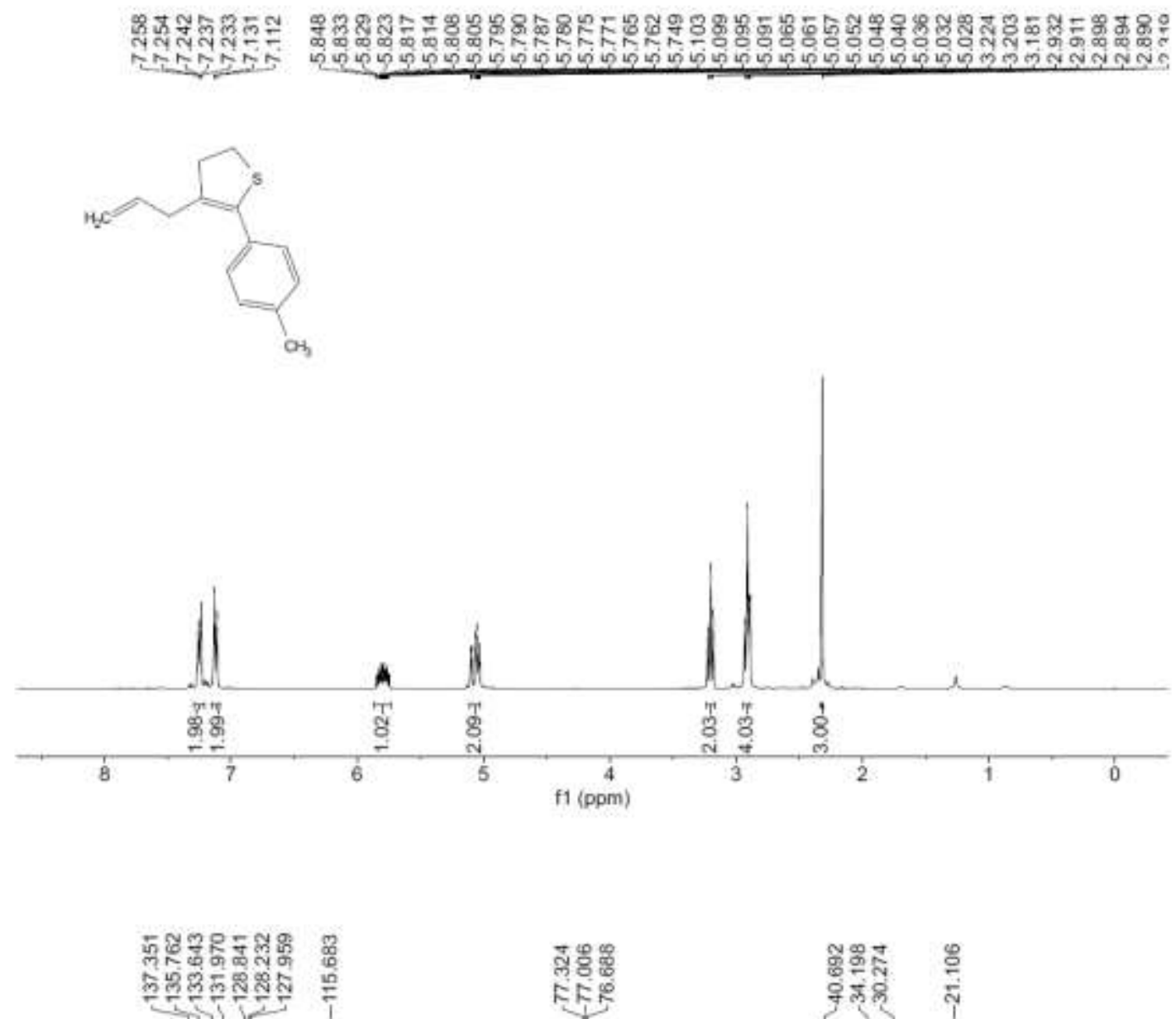

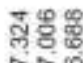

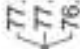

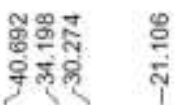
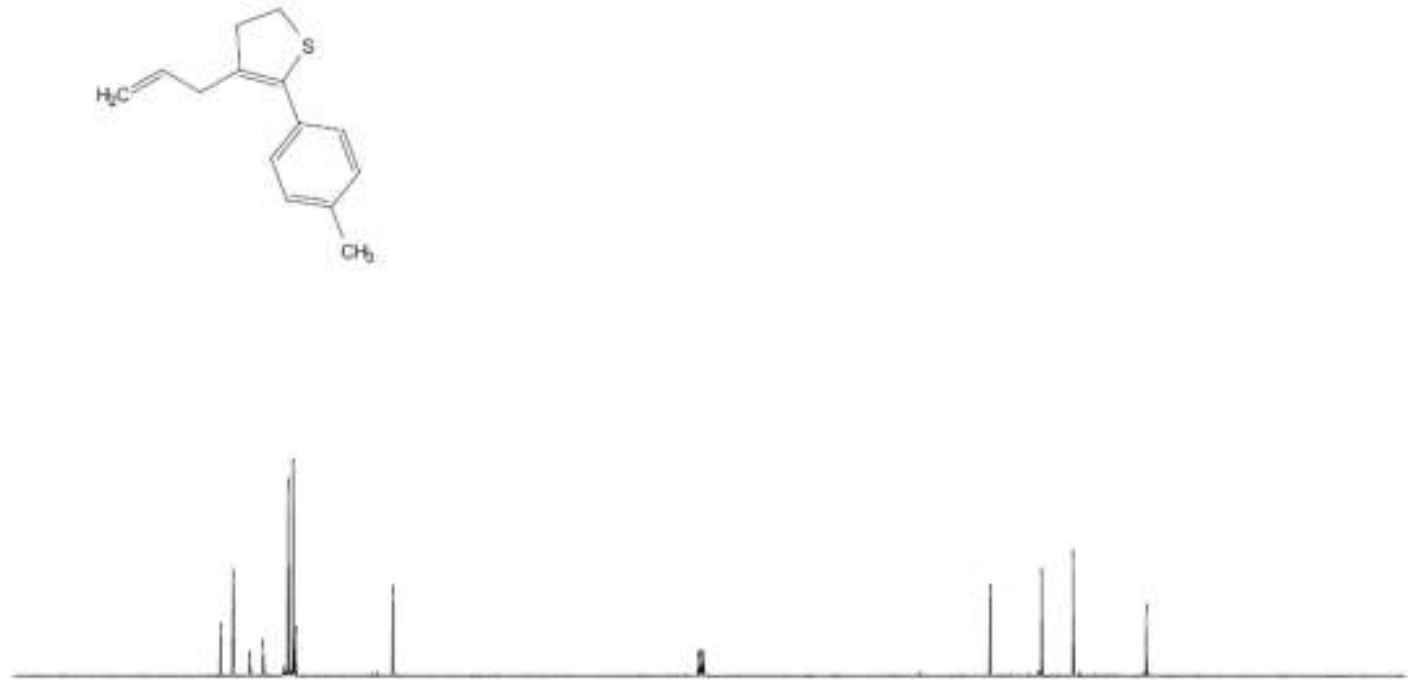

160

120

100

80

60

40

20

f1 (ppm)

${ }^{1} \mathrm{H}$ NMR (400 MHz) and ${ }^{13} \mathrm{C}\left\{{ }^{1} \mathrm{H}\right\}$ NMR (100 MHz) spectra of 7c in $\mathrm{CDCl}_{3}$ 

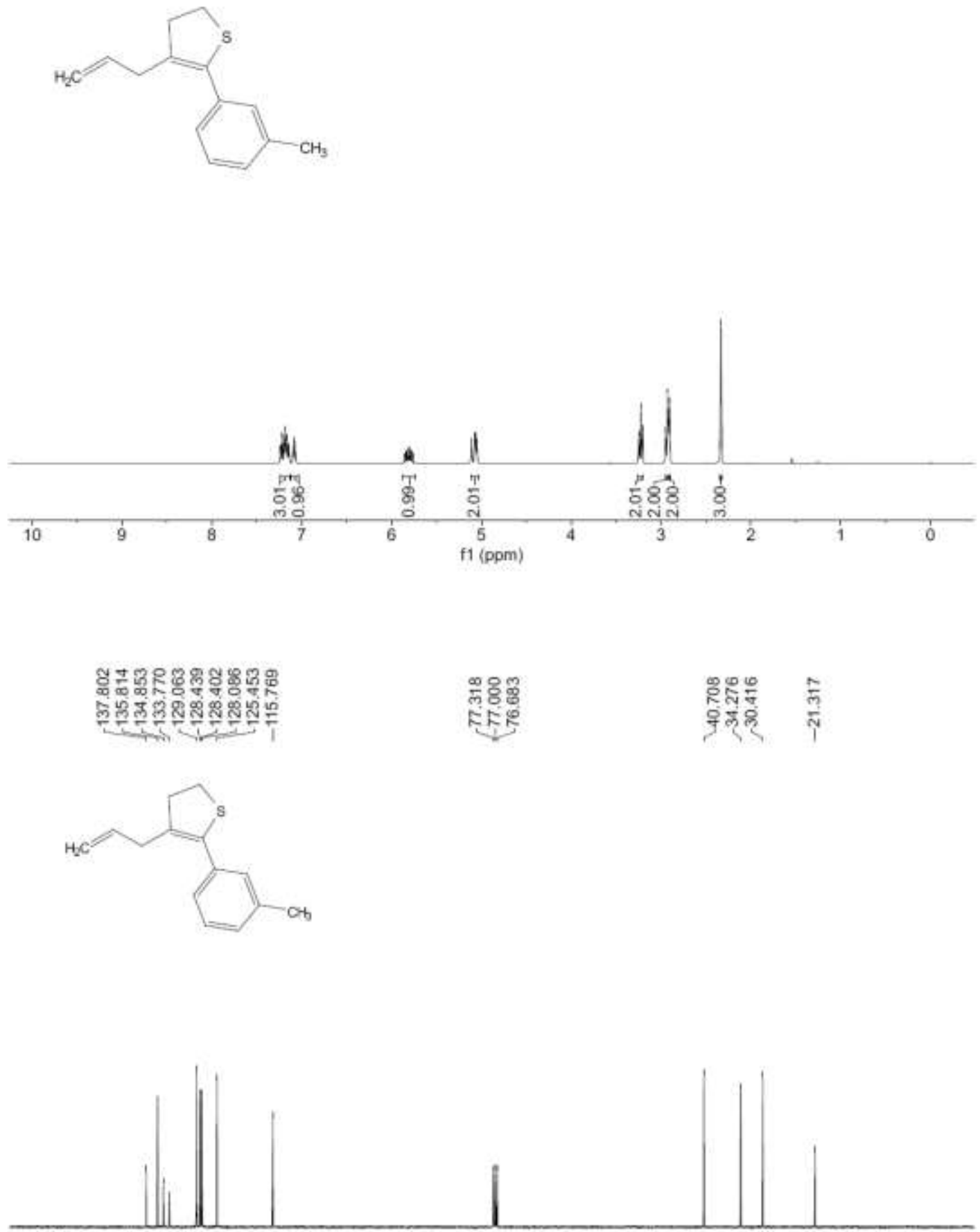

${ }^{1} \mathrm{H}$ NMR (400 MHz) and ${ }^{13} \mathrm{C}\left\{{ }^{1} \mathrm{H}\right\}$ NMR (100 MHz) spectra of 7d in $\mathrm{CDCl}_{3}$ 

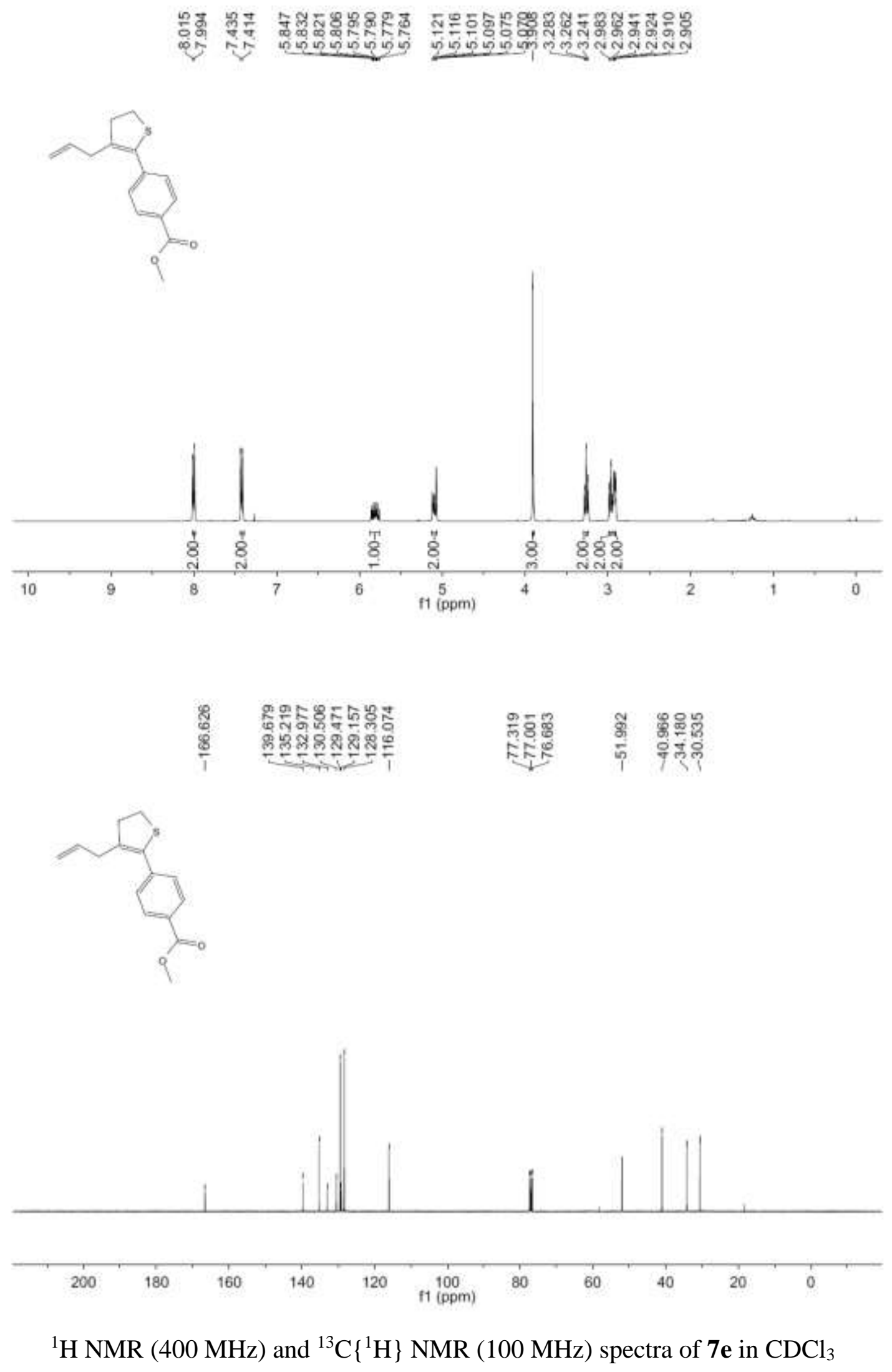

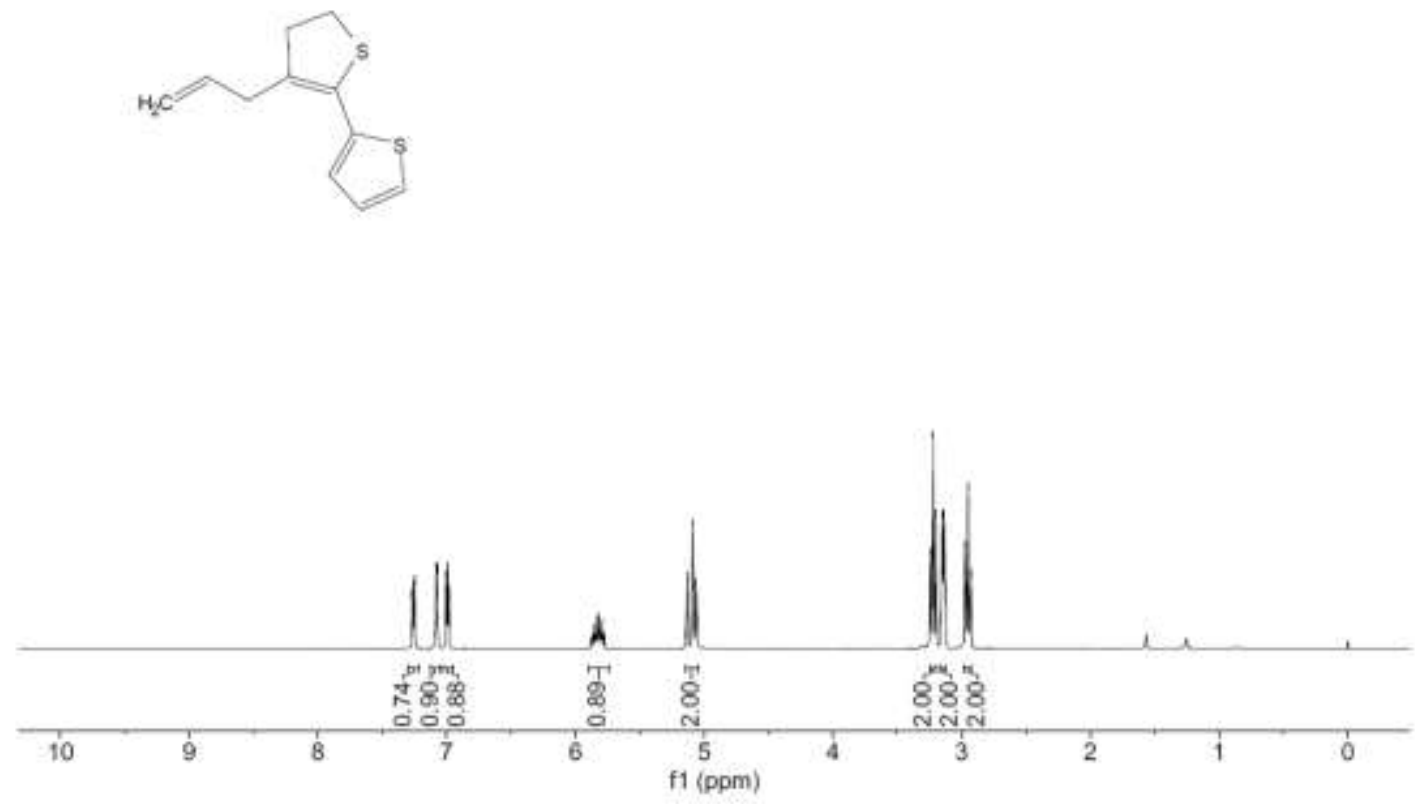

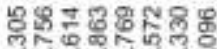

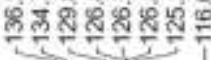

क유용

FR

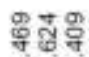

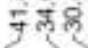
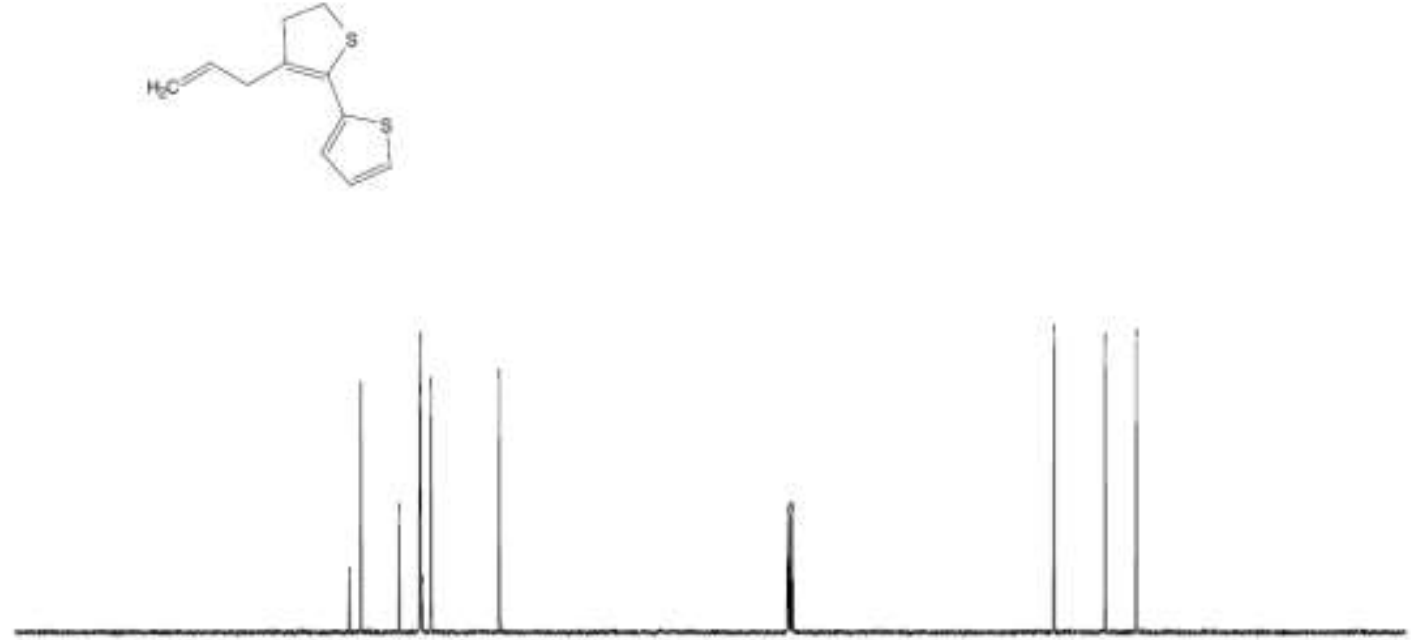

80

160

140

120

100

$30 \quad 60$

40

20

$\dot{0}$

${ }^{1} \mathrm{H}$ NMR (400 MHz) and ${ }^{13} \mathrm{C}\left\{{ }^{1} \mathrm{H}\right\}$ NMR (100 MHz) spectra of $7 \mathbf{f}$ in $\mathrm{CDCl}_{3}$ 